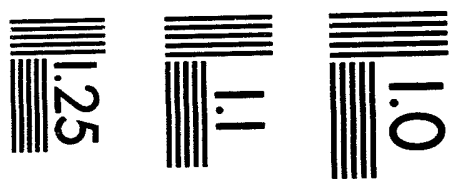

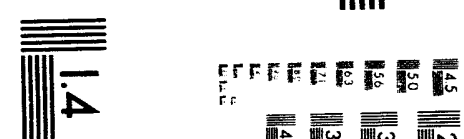

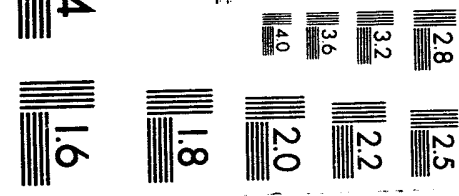



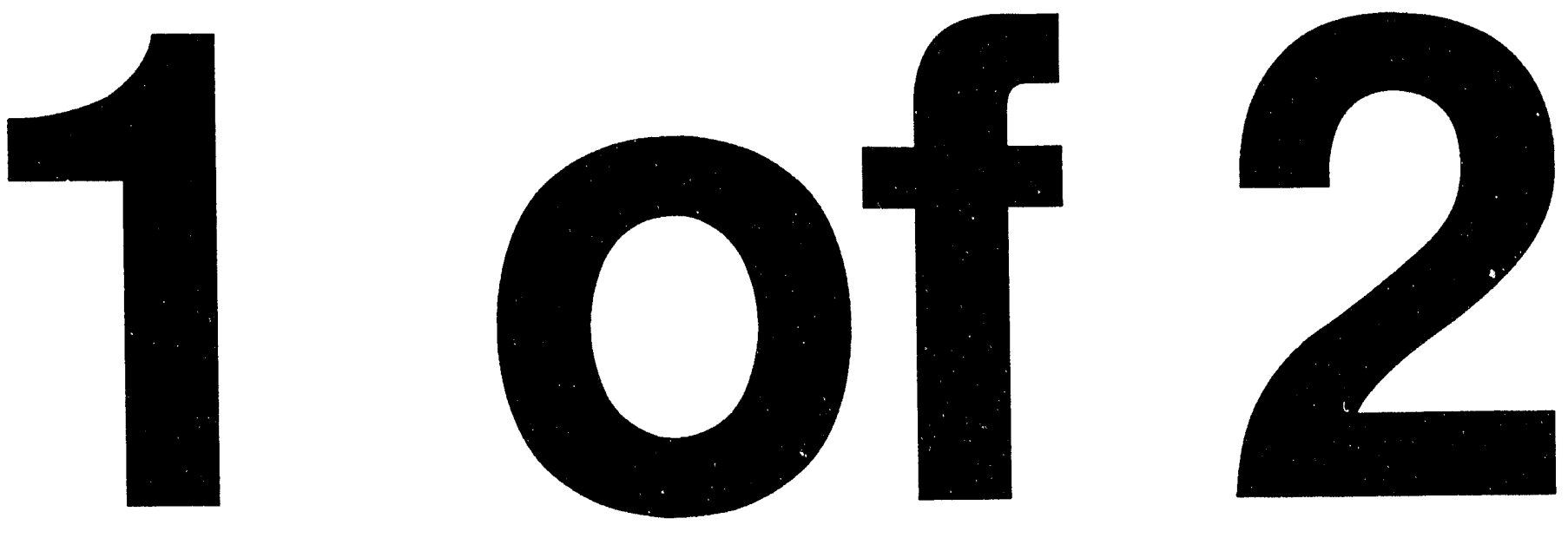


\section{Treatment Tests for Ex Situ Removal of Chromate, Nitrate, and Uranium (VI) from Hanford (100-HR-3) Groundwater Final Report}

Prepared for the U.S. Department of Energy Office of Environmental Restoration and Waste Management

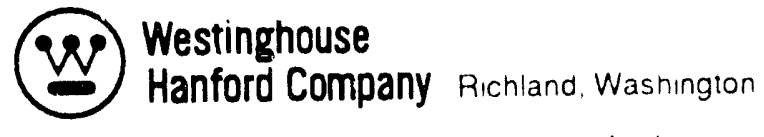

Hanford Operations and Engineering Contractor for the
US Department of Energy under Contraci DE.ACO6 87RL 10930 $\operatorname{mon} 25$ ands

OSTI 
सEB 2359

$\operatorname{lactax}=22$

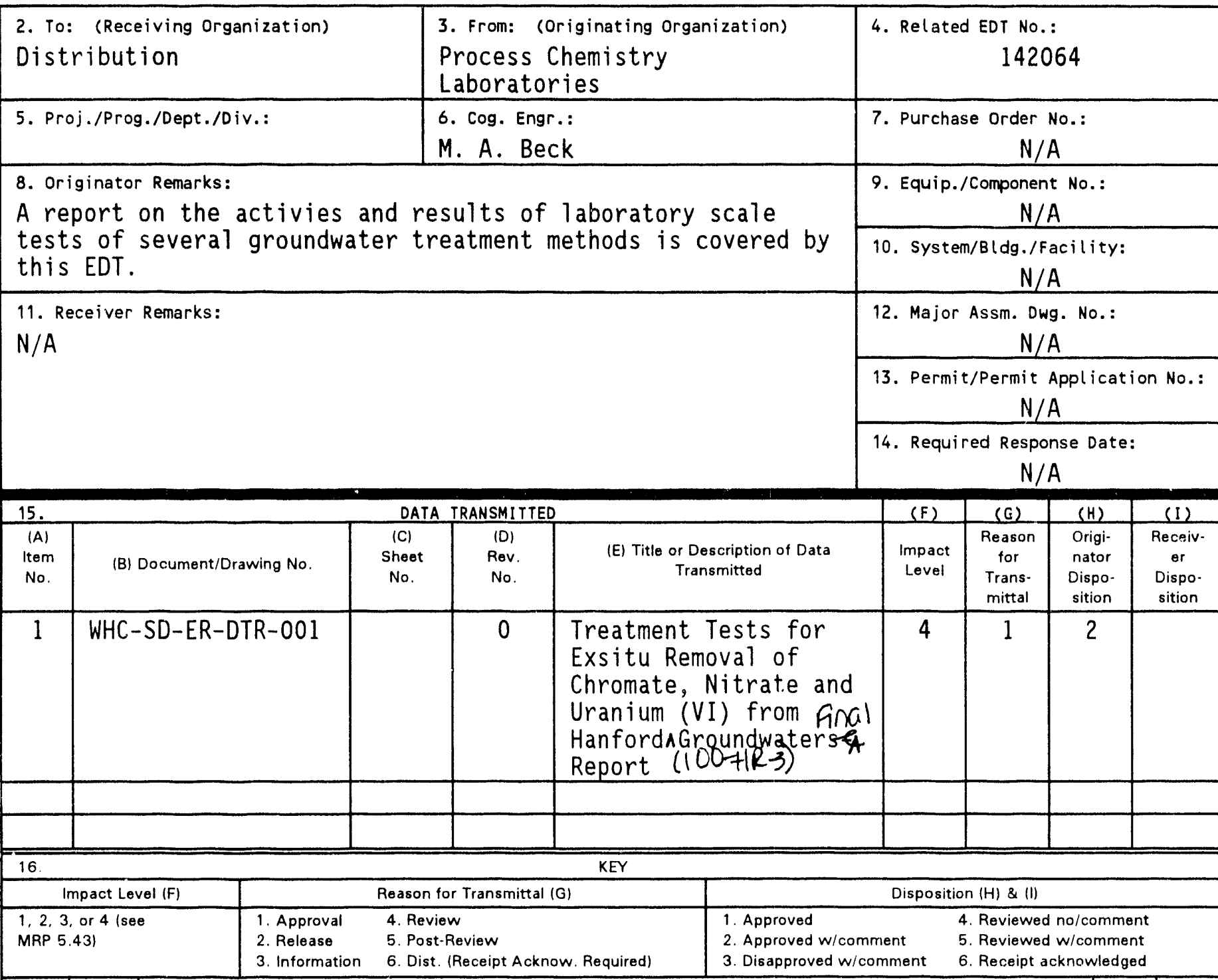

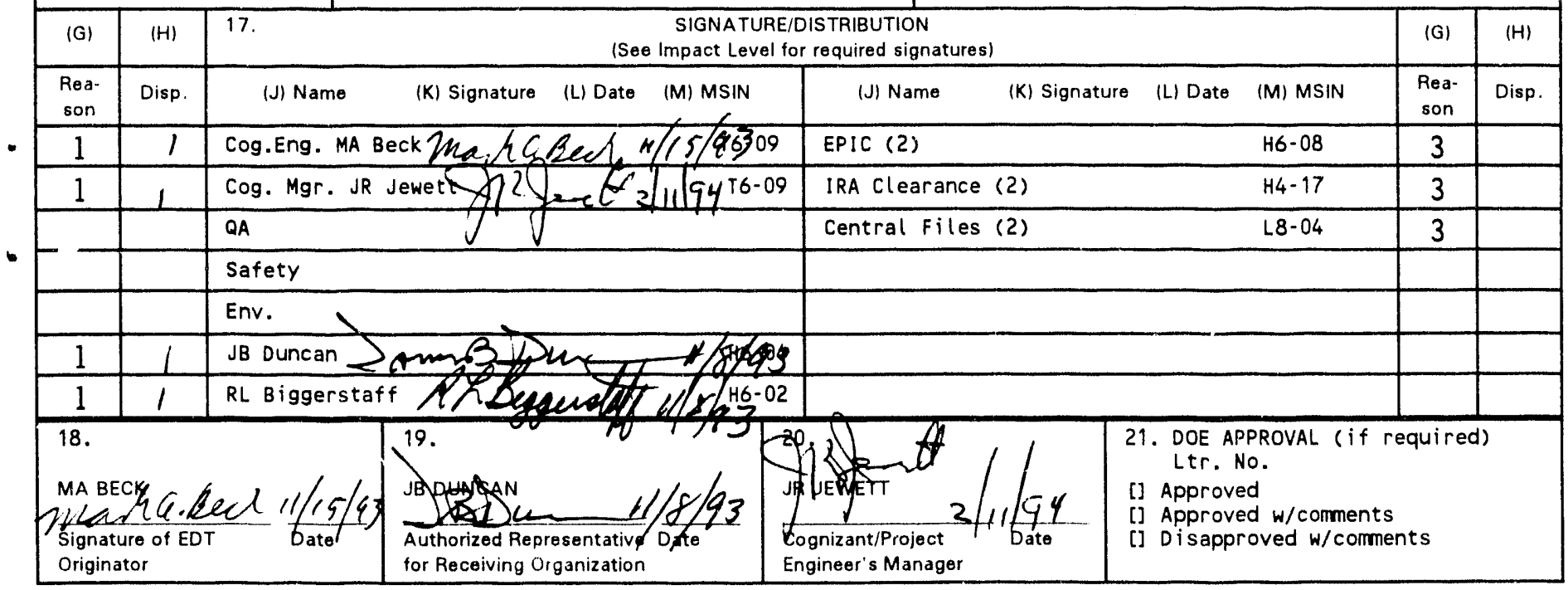

BD-7400-172-2(07/91) GEF097 


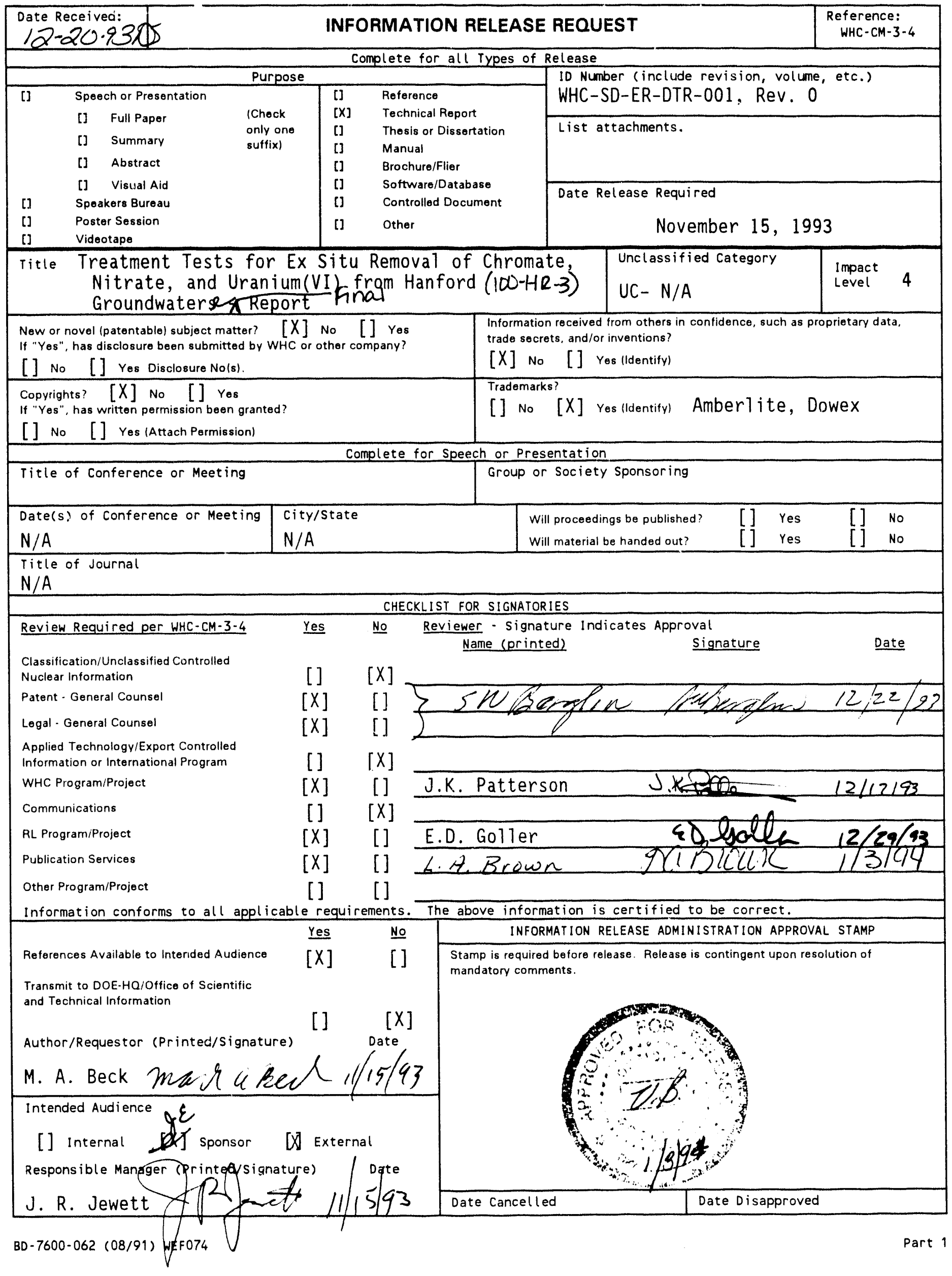


2. Title

Treatment Tests for Ex Situ Removal of Chromate Nitrate, and Uranium (VI) from Hanford (100-HR-3) Groundwaters Final Report

\section{Key Words}

nitrate, chromate, chromium, uranium, precipitation, ion exchange, groundwater, 100 Area

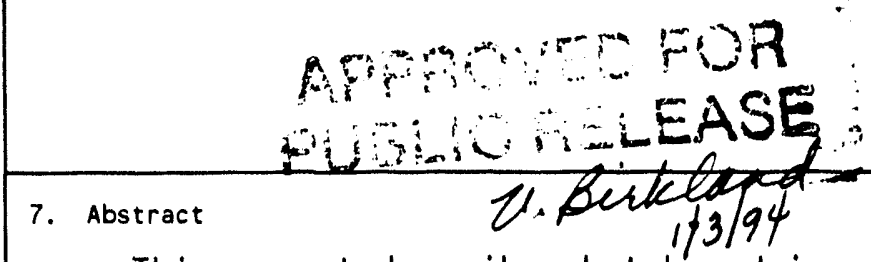

This report describes batch and ion exchange column laboratory scale studies investigating ex situ methods to remove chromate (chromium [VI]), nitrate $\left(\mathrm{NO}_{3}{ }^{-}\right.$) and uranium (present as uranium [VI]) from contaminated Hanford site groundwaters. The technologies investigated include: chemical precipitation or coprecipitation to remove chromate and uranium; and anion exchange to remove chromate, uranium and nitrate. The technologies investigated were specified in the 100-HR-3 Groundwater Treatability Test Plan. The method suggested for future study is anion exchange.

8. PURPOSE AND USE OF DOCUMENT. This document yas prepared for use within the U.S. Department of Energy and its/contractors. It is to be used only to perform, direch or integrate work under U.S. Deptartment of Energy contracts. This document is not approved for publia release unt il reviewed.

PATENT STMUO - This document coloy, since it is transmitted in advance of pateht clearance, is hade available in confidence solely for yoe in penformance of work under conzracts with the U.S. Department of Exergy. This document is not/to pe published ndr ito contents otherwise disseminated or used for purpoces other than opecified above before patent approval for such release or use has been secured, upon request, from the Patent Counsel, U.S. Department of Energy field Office, Richland, WA.

DISCLAIMER - This report was prepared as an account of work sponsored by an agency of the United States Government. Neither the United States Government nor any agency thereof, nor any of their employees, nor any of their contractors, subcontractors or their employees, makes any warranty, expressed or implied, or assumes any legal liability or responsibility for the accuracy, completeness or any third party's use or the results of such use of any information, apparatus, product, or process disclosed, or represents that its use would not infringe privately owned rights. Reference herein to any specific commercial product, process, or service by trade name, trademark, manufacturer, or otherwise, does not necessarily constitute or imply its endorsement, recommendation, or favoring by the United States Government or any agency thereof or its contractors or subcontractors. The views and opinions of authors expressed herein do not necessarily state or reflect those of the United States Government or any agency thereof.

9. Imoact Level 4
10.

RELEASE STAMP

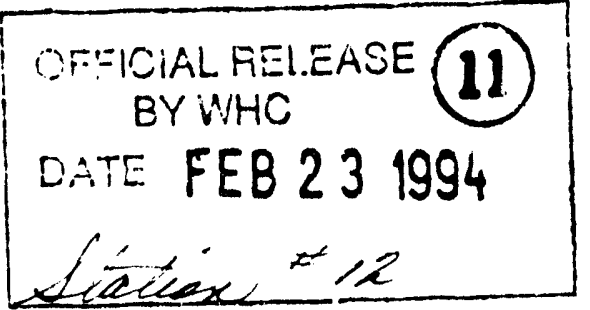



WHC-SD-ER-DTR-001, Rev. 0 
1.0 INTRODUCTION

1.1 BACKGROUND

2.0 PRECIPITATION METHODS

2.1 INTRODUCTION . . . . . . . . . . . . . . . . . . 2

2.2 EXPERIMENTAL . . . . . . . . . . . . . . . . . . . . 4

2.4 FERRIC CHLORIDE/COAGULANT AID TESTS . . . . . . . . . . . . . . . . 6

2.4.1 Experimental .................. 7

2.4.2 Quality Control .................. 9

2.4.3 Results..................... 9

3.0 ANION EXCHANGE METHODS ..................... 9

3.1 BATCH TESTS . . . . . . . . . . . . . . . . . . . . . . . 11

3.1.1 Experimental . . . . . . . . . . . . . . . . 11

3.1.2 Quality Control ................... . 11

3.1.3 Results..................... . 11

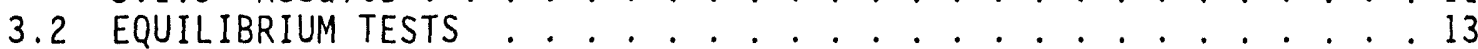

3.2.1 Introduction . . . . . . . . . . . . . . . . . . . . 13

3.2.2 Experimental . . . . . . . . . . . . . . . 13

3.2.3 Quality Control .. . . . . . . . . . . . . . . 14

3.2.4 Results.................... . 14

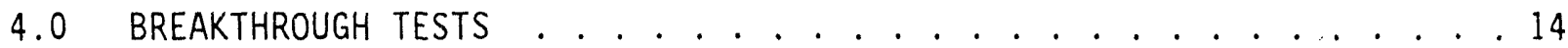

4.1 EXPERIMENTAL . . . . . . . . . . . . . . . . . . . . 15

4.2 QUALITY CONTROL .. . . . . . . . . . . . . . . . . . . . . . 16

4.3 RESULTS AND DISCUSSION . . . . . . . . . . . . . . . . . . . . . . 16

4.3.1 Low Flow Rate, Spiked Groundwater. . . . . . . . . . . 16

4.3.2 High Flow Rate, Spiked Groundwater . . . . . . . . . . . 17

4.3.3 Well 199-H4-4 Unspiked Groundwater . . . . . . . . . . . 17

4.3.4 Well 199-05-15 Unspiked Groundwater . . . . . . . . . . . 18

4.3.5 Biodenitrified Groundwater . . . . . . . . . . . . 18

4.3.6 Very High Spiked Groundwater, Low Flow Rate. . . . . . . 18

4.3.7 Total Alpha and Total Beta Analyses.......... . . . 19

4.3.8 Common Themes in the Breakthrough Results... . . . . . 20

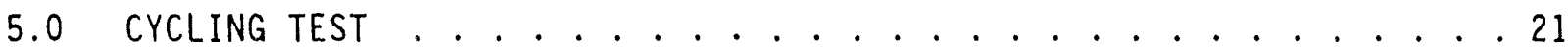

5.1 EXPERIMENTAL . . . . . . . . . . . . . . . . . . . . 21

5.2 RESULTS . . . . . . . . . . . . . . . . . . . . . 22

5.2.1 Treated Effluent . . . . . . . . . . . . . . 22

5.2.2 Eluate .................... . . 23

5.2.3 Wash ...................... . 24

5.2.4 Common Themes . . . . . . . . . . . . . . . . . . 24

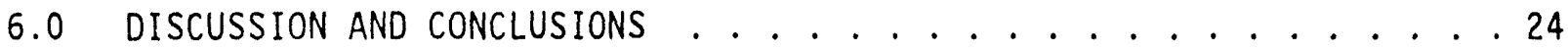

6.1 URANIUM ........................ 25

6.2 TECHNETIUM ......................... 25

6.3 BATCH TESTS . . . . . . . . . . . . . . . . . . . . . 25

6.3.1 Precipitation Methods . . . . . . . . . . . . . . 25

6.3.2 Anion Exchange Resins... . . . . . . . . . . . . 27

6.4 FERRIC CHLORIDE/COAGULANT AID TESTS . . . . . . . . . . . . . . . . . . 28

6.5 EQUILIBRIUM TESTS ..................... 28 
WHC-SD-ER-DTR-001, Rev. 0

CONTENTS (cont.)

6.6 BREAKTHROUGH TESTS ................... 29

6.7 CYCLING TESTS .......................... 29

6.8 RECOMMENDATIONS . . . . . . . . . . . . . . . . . . . . . . . . 29

7.0 REFERENCES ....................... 30

\section{APPENDIXES:}

A CONCENTRATION VALUES ANALYTICALL BLANK AND SAMPLE 199-H3-2C . . . A-1

B FILTER METHOD TEST DATA . . . . . . . . . . . . . . B-1

C RAW DATA FROM THE SODIUM SULFIDE-FERROUS SULPHATE PRECIPITATION

BATCH TEST AND THE SODIUM PHOSPHATE PRECIPITATION BATCH TEST . . . c c-1

D RAW DATA FROM ANION RESIN BATCH TESTS . . . . . . . . . . . . . . . . $D-1$

E REGRESSION COEFFICIENT VALUES FOR ANION EXCHANGE METHODS . . . . . E-1

F EQUILIBRIUM EXPERIMENT DATA . . . . . . . . . . . . . . . . . . . . F-1

G RESULTS OF THE LOW FLOW RATE SPIKED GROUNDWATER (WELL 199-H3-2C)

BREAKTHROUGH TEST . . . . . . . . . . . . . . . G-1

H RESULTS OF THE HIGH FLOW RATE SPIKED GROUNDWATER (WELL 199-H3-2C)

BREAKTHROUGH TEST . . . . . . . . . . . . . . . . . . . H-1

I RESULTS OF THE UNSPIKED GROUNDWATER (WELL 199-H4-4)

BREAKTHROJGH TEST . . . . . . . . . . . . . . . . . . . . . . . I-1

J RESULTS OF THE UNSPIKED GROUNDWATER (WELL 199-D5-15)

BREAKTHROUGH TEST . . . . . . . . . . . . . . . . . . . J-1

$K$ RESULTS OF THE BIODENITRIFIED GROUNDWATER (WELLS 199-H4-4 AND

199-D5-15) BREAKTHROUGH TEST . . . . . . . . . . . . . . . . . . K-1

L RESULTS OF THE LOW FLOW RATE VERY HIGH SPIKED GROUNDWATER

(WELL 199-H3-2C) BREAKTHROUGH TEST . . . . . . . . . . . . . L-1

M CYCLING TEST

$M-1$

\section{TABLES:}

1. Performance Goals ........................ 1

2. Chemical Analyses...................... 3

3. Average Decontamination Factors for Precipitation Methods . . . . . . 5

4. Contaminant Levels . . . . . . . . . . . . . . . . 8

5. Physical Response Parameters . . . . . . . . . . . . . 10

6. Distance of Floc Line from Top of Water. . . . . . . . . . . . 10

7. Chemical Analysis...................... 10

8. Average Decontamination Factors--Anion Exchange Resin Methods

High Initial Concentration Decontamination Factors . . . . . . . . . 12

9. Values for Starting Solutions . . . . . . . . . . . . . . 20 
WHC-SD-ER-DTR-001, Rev. 0

\subsection{INTRODUCTION}

This report describes batch and anion exchange column laboratory-scale studies investigating ex situ methoc's to remove chromate (chromium [VI]), nitrate $\left(\mathrm{NO}_{3}^{-}\right)$, and uranium (present as uranyl (uranium [VI]) carbonato anionic species) from contaminated Hanford Site groundwaters. The technologies investigated include chemical precipitation or coprecipitation to remove chromate and uranium, and anion exchange to remove chromate, uranium, and nitrate. The technologies investigated were specified in the 100-HR-3 Groundwater Treatability Test Plan (DOE-RL 1993). The goal of these tests was to determine the best method to remove selected contaminants to below the concentration of the project performance goals (Table 1). The raw data and observations made during these tests can be found in the Westinghouse Hanford Company (WHC) laboratory notebooks (Beck 1992, Herting 1993).

The method recommended for future study is anion exchange with Dowex $21 \mathrm{~K}$ resin.

\subsection{BACKGROUND}

The 100-HR-3 Operable Unit is a groundwater unit near the 100-H Reactor. Due to past reactor operations, the groundwater has become contaminated with uranium, chromate, and nitrate. The uranium is most likely in the form of a uranyl carbonato anion complex $\left[\mathrm{UO}_{2}\left(\mathrm{CO}_{3}\right)_{3}\right]^{-2}$ (IT Corp. 1989, Appendix F). Chromium is present in the groundwater as chromate. Nitrate is also present in this groundwater. Analyses of an uncontaminated well (119-H3-2) from the 100-H Area are presented in Appendix A. The concentrations of selected contaminants for the wells selected for testing can be found in the data on breakthrough tests.

Table 1. Performance Goals (DOE-RL 1993).

\begin{tabular}{|l|c|}
\hline \multicolumn{1}{|c|}{ Contaminant } & Performance goal \\
\hline Total alpha, $\mathrm{pCi} / \mathrm{L}$ & $15^{\mathrm{a}}$ \\
Total beta, $\mathrm{pCi} / \mathrm{L}$ & $40^{\mathrm{b}}$ \\
Chromium (total), $\mu \mathrm{g} / \mathrm{L}$ & $100^{\mathrm{a}}$ \\
Nitrate (as NO & ) $\mu \mathrm{g} / \mathrm{L}$ \\
Uranium, $\mu \mathrm{g} / \mathrm{L}$ & $45,000^{\mathrm{a}}$ \\
\hline
\end{tabular}

a Maximum Contaminant Level (40 CFR 141).

balue is $0.04 \times$ Derived Concentration

Guide for radionuclides in water (WHC 1988).

'Derived from the total alpha

performance goal, assuming natural uranium isotopic composition. 
WHC-SD-ER-DTR-001, Rev. 0

The wells tested were selected in the Test Plan (DOE-RL 1993) to provide a wide range of contaminant levels and to be representative of the groundwater found in the 100-HR-3 Operable Unit. Well 199-H3-2C was used as an uncontaminated starting material for spiking. The spiking levels for nitrate and chromate were chosen to represent the upper bound on groundwater contamination in the 100-H Area. The uranium spiking level was chosen to be considerably above the upper bound of likely groundwater contamination, so that the efficacy of treatment could be ascertained. The uranium spike level was planned to be about $800 \mathrm{ppb}$; however, due to difficulties in spiking, the actual level was less and is reported along with each test.

The selection of analytes, contaminants for removal, and considerable background are topics discussed at length in the Test Plan (DOE-RL 1993) and the Test Procedures (Beck and Delegard 1993). To avoid duplication, those discussions will not be repeated here. The major thrust of this series of tests is to determine which of several treatment options will remove the contaminants of interest from ambient (not $\mathrm{pH}$ adjusted) groundwater from the 100-HR-3 Operable Unit.

The analytical methods used are presented in Table 2.

\subsection{PRECIPITATION METHODS}

\subsection{INTRODUCTION}

Two precipitation methods, sulfide precipitation and brushite coprecipitation, were tested for removal of contaminants. The ferrous sulfate/sodium sulfide method was specified in the Test Plan (DOE-RL 1993) as a likely method for chromate reduction and removal. The brushite coprecipitation method was specified by Beck and Delegard (1993) as a likely method of uranium removal. The goal of the precipitation tests was to determine if the uranium and/or chromium could be removed to less than the performance goals specified in the Test Plan (DOE-RL 1993) and Table 1 of this document .

The chemical rationale for the sulfide method was to use sodium sulfide $\left(\mathrm{Na}_{2} \mathrm{~S}\right)$ and ferrous sulfate $\left(\mathrm{FeSO}_{4}\right)$ to first reduce $\mathrm{Cr}$ (VI) to $\mathrm{Cr}$ (III) and then to coprecipitate the reduced chromium with the resulting ferric hydroxide $\left(\mathrm{Fe}(\mathrm{OH})_{3}\right)$ and/or ferric sulfide $\left(\mathrm{Fe}_{x} \mathrm{~S}_{y}\right)$. The possible reduction and/or precipitation and retention of uranium (VI) by this technique was also tested. Refer to the Test Procedures (Beck and Delegard 1993) for a more complete discussion and references to the literature. 
WHC-SD-ER-DTR-001, Rev. 0

Table 2. Chemical Analyses.

\begin{tabular}{|c|c|c|c|}
\hline Analyte(s) & Method \# & Title & $\begin{array}{l}\text { Minimum } \\
\text { detection } \\
\text { limit }\end{array}$ \\
\hline $\begin{array}{l}\text { Cations } \\
\text { (ICP) }\end{array}$ & $L A-505-241$ & $\begin{array}{l}\text { ICP Emission Spectrometer } \\
\text { Method for Trace Element } \\
\text { Analysis of water and } \\
\text { waste }\end{array}$ & $50 \mathrm{ppb}$ \\
\hline $\begin{array}{l}\text { Total } \\
\text { chromium }\end{array}$ & $\begin{array}{l}\text { LA-505-151 } \\
\text { LA-505-241 }\end{array}$ & $\begin{array}{l}\text { ICP Emission Spectrometer } \\
\text { Method for Trace Element } \\
\text { Analysis of water and } \\
\text { waste }\end{array}$ & $29 \mathrm{ppb}$ \\
\hline Chromium(VI) & $L A-265-101$ & $\begin{array}{l}\text { Spectrophotometric } \\
\text { determination of } \mathrm{Cr} \text { (VI) }\end{array}$ & $19 \mathrm{ppb}$ \\
\hline Anion (IC) & $\begin{array}{l}\text { LA-533- }-3 \\
\text { LA-533-201 }\end{array}$ & $\begin{array}{l}\text { Anion analysis on Dionex } \\
\text { Model } 4000 i\end{array}$ & $\begin{array}{l}10,000 \\
\mathrm{ppb}\end{array}$ \\
\hline Nitrate & $\begin{array}{l}L A-533-105 \\
\text { LA-533-201 }\end{array}$ & $\begin{array}{l}\text { Anion analysis on Dionex } \\
\text { Model } 4000 i\end{array}$ & $\begin{array}{l}10,000 \\
\mathrm{ppb}\end{array}$ \\
\hline Uranium & $\angle A-925-007$ & $\begin{array}{l}\text { Uranium by laser induced } \\
\text { kinetic phosphorescence }\end{array}$ & $1 \mathrm{ppb} U$ \\
\hline $\begin{array}{l}\text { Total } \\
\text { organic } \\
\text { carbon }\end{array}$ & $L A-344-105$ & $\begin{array}{l}\text { Determination of carbon } \\
\text { in solutions by } \\
\text { combustion and coulometry }\end{array}$ & $N / A$ \\
\hline $\begin{array}{l}\text { Total } \\
\text { inorganic } \\
\text { carbon }\end{array}$ & $L A-622-102$ & $\begin{array}{l}\text { Determination of } \\
\text { carbonate/carbon or TIC } \\
\text { in solutions by } \\
\text { coulometry }\end{array}$ & $N / A$ \\
\hline $\begin{array}{l}\text { Total alpha } \\
\text { and total } \\
\text { beta }\end{array}$ & $L A-548-203$ & $\begin{array}{l}\text { Alpha and beta in liquid } \\
\text { sample }\end{array}$ & \\
\hline $\mathrm{pH}$ & $L A-212-102$ & $\begin{array}{l}\text { Determination of } \mathrm{pH} \\
\text { direct measurement }\end{array}$ & $N / A$ \\
\hline
\end{tabular}

N/A - The actual detection limit is determined by the amount of sample available and the count.

Simple addition of disodium hydrogen phosphate $\left(\mathrm{Na}_{2} \mathrm{HPO}_{4}\right)$ to precipitate brushite $\left(\mathrm{CaHPO}_{4}\right)$ from the contained calcium ion naturalfy present in the Hanford site groundwater was tested for its efficacy in removing U(VI). Scouting experiments showed that additional calcium ion, introduced as calcium chloride $\left(\mathrm{CaCl}_{2}\right)$ solution to the groundwater, was required to provide sufficient precipitate to carry uranium. The incidental removal of chromate from solution by coprecipitation with brushite was also investigated.

Neither of these methods was expected to provide nitrate removal. 


\subsection{EXPERIMENTAL}

The precipitation tests were conducted by adding the precipitating agents to $30 \mathrm{~mL}$ of spiked groundwater solution, then stirring via a magnetic stir bar for 30 minutes, followed by 3 minutes of centrifugation. A setting of " 5 " on an International Equipment Company clinical centrifuge was used, yielding a "g" force of $320 \pm 130 \mathrm{~g}$ (at 9u\% confidence) at the top of the $30 \mathrm{~mL}$ of water and $600 \pm 250 \mathrm{~g}$ at the bottom of the centrifuge cone. The samples were then filtered, using a $0.45-\mu \mathrm{m}$ cellulose acetate filter. The sodium sulfide/ferrous sulfate treatment was accomplished by adding a dilute stock solution of sodium sulfide to produce $12 \mathrm{mg} \mathrm{s}^{-2} / \mathrm{L}$ in the final test solution, and then adding ferrous sulfate stock solution to produce $9.9 \mathrm{mg} \mathrm{Fe} / \mathrm{L}$ in the final test solution. The phosphate treatment was accomplished by adding sodium hydrogen phosphate stock solution to produce $5,550 \mathrm{mg} \mathrm{HPO}_{4}^{-2} / \mathrm{L}$ in the final solution and calcium chloride stock solution sufficient to produce (in conjunction with natural calcium) $92 \mathrm{mg} \mathrm{Ca} / \mathrm{L}$. The levels of $\mathrm{HPO}_{4}^{-2}$ and $\mathrm{Ca}^{+2}$ were determined in scouting experiments as those levels that gave the best precipitation, as determined by visual observation.

The test was a full factorial experiment, which means that all combinations of the variables of interest (uranium, nitrate, chromium) were explored. Each variable had two levels, which yields eight different solutions (to vary the concentrations of contaminants). Each test was performed in duplicate. Blanks and standards were shipped with each ratch of samples. Due to the small amounts of sample, no replicate analyses were done.

\subsubsection{Quality Control}

All precipitation tests were done in duplicate. Method blanks and standards were sent with each batch of samples. Analytical quality control (performed at PUREX Laboratory) included standards with every batch run for all the analyses. All standards fell within acceptable ( $\pm 20 \%$ relative standard deviation) limits. No contamination was detected in the method blanks. A test of the effect of the filtering process on the concentrations of contaminants was performed. No effect from filtering could be seen (Appendix B). Values of chromium were higher after treatment for some samples (EBPS1501, EBPD1501, EBPS1601, EBPD1601) than the starting concentrations. No apparent explanation for this discrepancy exists.

\subsection{RESULTS}

Table 3 summarizes the results of the batch tests for the precipitation tests. The data that Table 3 summarizes can be found in Appendix $C$. The decontamination factor (DF) is the original concentration of the contaminant, as determined by the laboratory, divided by the amount found after treatment.

$$
D F=C_{0} / C_{f i n a t}
$$


Tabie 3. Average Decontamination Factors for Precipitation Methods.

\begin{tabular}{|l|c|c|c|c|}
\hline \multicolumn{1}{|c|}{ Method } & Uranium & Nitrate & $\begin{array}{c}\text { Total } \\
\text { chromium } \\
\text { by ICP }\end{array}$ & $\begin{array}{c}\text { Chromium } \\
\text { (VI) }\end{array}$ \\
\hline $\begin{array}{l}\text { Sodium sulfide/ } \\
\text { ferrous sulfate }\end{array}$ & $1.3^{\mathrm{a}}$ & 0.9 & 9.6 & 64 \\
\hline $\begin{array}{l}\text { Sodium hydrogen } \\
\text { phosphate without } \\
\text { added calcium } \\
\text { chloride }\end{array}$ & 0.9 & 1.0 & 1.2 & 1.2 \\
\hline $\begin{array}{l}\text { Sodium hydrogen } \\
\text { phusphate with added } \\
\text { calcium chloride }\end{array}$ & 32 & 1.1 & 0.9 & 1.6 \\
\hline Filter alone & 0.9 & 1.0 & 1.3 & 0.9 \\
\hline $\begin{array}{l}\text { Standard, no } \\
\text { treatment }\end{array}$ & 1.5 & 1.0 & 1.3 & 1.9 \\
\hline
\end{tabular}

${ }^{a}$ The data do not support more significant figures than shown in this table.

Higher numbers denote more complete removal of the contaminant from the groundwater. The approximate initial concentrations for the high-level spike are $2,000 \mathrm{ppb}$ for total chromium [chromium by inductively coupled plasmaatomic emission spectroscopy (also referred to as $\mathrm{Cr}$-ICP)] and $\mathrm{Cr}(\mathrm{VI}), 600 \mathrm{ppb}$ for uranium, and $200,000 \mathrm{ppb}$ for nitrate. In this report concentrations are given in terms of parts per billion, which is equivalent to micrograms per liter. Because of experimental errors and the fact that the DF is a ratio, the DFs can be skewed. DF values less than about 2 are not significant, because the standard has DF values not equal to 1 (no apparent change in concentration). The change in concentration could be caused by adsorption of the contaminants (which are at very low levels) onto the wall of the sample container.

The sulfide/ferrous sulfate treatment resulted in a very dark colloidal suspension that was not removed upon centrifugation. This colloidal suspension was, however, removed upon filtration. The volume of material on the filter following was smaller than $1 \mathrm{~mL}$ but, due to the small amount of solution treated per test and the corresponding small amount of residue, no measurement of the exact mass or volume was performed. The phosphate-calcium chloride treatment resulted in a fluffy white precipitate that was removed by centrifugation but settled very slowly in gravity settling tests. The phosphate-calcium chloride process precipitate was about one-tenth of the original solution volume before centrifuging and one one-hundredth of the original solution volume after centrifuging. All steps in the process, save the addition of the reagents, were shown to have no significant effect on the concentration of the contaminants.

The high DFs shown in Table 3 may, in fact, be lower than the actual DFs. This is because the limit of detection of the chemical analys is methods 
WHC-SD-ER-DTR-001, Rev. 0

as often reached. The limit of detection was used as a final concentration value for those tests in which the final concentration is reported as less than the detection limit. The DFs produced by experimental method (centrifugation and filtration) used are likely to be higher than the DFs produced by a gravity settling and decanting technique, as the method used removed all of the suspension by filtering.

Two conclusions can be drawn: (1) the sodium sulfide, ferrous sulfate treatment removes chromium, especially hexavalent chromium, and (2) the phosphate-calcium chloride treatment produces significant DFs with uranium. Both conclusions are those expected from the literature review. The sulfide treatment fails to remove uranium and the phosphate treatment does not produce significant DFs with chromium. Both treatment methods have little effect on the nitrate concentration.

The authors are unable to distinguish any effect the other contaminants had on uranium removal by the phosphate method. The apparent effect of nitrate on uranium removal by the phosphate-calcium chloride method may be an artifact of high limits of detections due to insufficient sample. Higher DFs are found in solutions with a high original amount of uranium, probably due to the above-mentioned effect of the limit of detection on the DF. No effect of $\mathrm{pH}$ on any batch test (precipitation or anion exchange) could be determined because the experimental procedure did not supply the laboratory with enough sample to perform $\mathrm{pH}$ measurements.

The sulfide/ferrous sulfate method removes the chromium (both total chromium and hexavalent chromium). It can be shown that a higher nitrate concentration increased the DF of total chromium ( $\mathrm{Cr}-\mathrm{ICP})$. The uranium concentration has no effect on the chromium DF. The effect of the limit of detection on the DF is the same as for uranium removal. No effect of other contaminants could be determined, since the detection limit became the lower bound for all final concentrations, thereby yielding the same DF for the same original concentration.

Neither method, as performed in these batch tests, produced easily gravity-settled flocculant. The sulfide tests were especially prone to producing a flocculant that could not be centrifuged. The DFs found may be an effect of the filtering process, instead of centrifugation. Filtering may have removed colloidal particles (which were not removed by centrifuging).

Because neither precipitation method removed both chromium and uranium from solution and each method generated significant quantities of sludge or flocculant, further tests were considered to be superfluous. No concentration-versus-time kinetic study was done as proposed in the Test Procedures (Beck and Delegard 1993).

\subsection{FERRIC CHLORIDE/COAGULANT AID TESTS}

The removal of colloids and colloidal flocs (due to incomplete agglomeration and relatively small nucleation) has been a part of water and wastewater treatment for decades.

The solid-liquid separation involves two stages: coagulation (charge neutralization and microfloc formation) and flocculation (Raman 1981). 
WHC-SD-ER-DTR-001, Rev. 0

Coagulation (which may be accomplished with iron salts $\mathrm{FeSO}_{4}, \mathrm{Fe}_{2}\left(\mathrm{SO}_{4}\right)_{3}$, and $\mathrm{FeCl}_{3}$ ) is merely the negation of influence of the diffuse layer of counterions around the negatively chairged colloid (Sawyer and McCarty 1978).

The action of a polymer in flocculation is to accelerate the gravitational forces overcoming inertial forces by adsorption and interparticle bridging (Weber 1972).

The polymer selected for this study was CAT-FLOC L (a trademark of the Calgon Corporation), a medium molecular weight low monomer cationic polyelectrolyte. The polymer is used as a coagulant aid in water clarification in conjunction with ferric salts. CAT-FLOC is a chlorine-resistant polymer and effective over a broad $\mathrm{pH}$ range.

\subsubsection{Experimental}

A solution of ferric chloride was made up to $30 \mathrm{mg} / \mathrm{L}$ iron in deionized, 18 megaohm water. A solution of CAT-FLOC L was made up to $5 \mathrm{mg} / \mathrm{L}$ ( $\mathrm{sp} \mathrm{gr}$ $1.032 \mathrm{~g} / \mathrm{mL}$ ) in deionized, 18 megaohm water.

Water from the 100-HR-3 Area we11s, 199-H4-4 and 199-D5-15, was used as the test matrix. Changes were made to the well numbers. The choice of the wells was explained in 100-HR-3 Groundwater Treatability Test Plan (DOE-RL 1993). The contaminants of concern were chromate as chrome (VI), nitrate, and uranium [as uranium (VI) due to the contribution to total alpha and total beta]. Table 4 lists the values as reported in the Hanford Environmental Information System Analys is for 100-HR-3 Groundwater, sampled during the 1992 sampling campaign; this table is also contained in DOE-RL (1993) as Table 1-1.

Table 1 listed the performance goals for each of the contaminants. This table is also contained in 100-HR-3 Groundwater Treatability Test Plan (DOE-RL 1993, Table 1-1).

To obtain a high turbulence during the initial mixing (rapid mix) phase and ensure complete mixing, a Phipps-Bird paddle stirrer was used. According to Hudson (1981), the jar test (using a Phipps-Bird or equivalent paddle mixer) is the most widely used method to evaluate coagulation-flocculation processes.

Turbidity measurements-were made with a HACH Model $2100 \mathrm{~A}$ Turbidimeter and standardized against HACH turbidity standards supplied with the instrument.

Before any $\mathrm{pH}$ measurements were made, the instrument was standardized with the appropriate buffers.

Total solids were measured by evaporating a known volume of sample in a tared evaporating dish at $110^{\circ} \mathrm{C}$. 
Table 4. Contaminant Levels (DOE-RL 1993).

\begin{tabular}{|l|c|c|}
\hline \multicolumn{1}{|c|}{ Contaminant } & Wel1 199-H4-4 & Well 199-D5-15 \\
\hline Gross alpha, $\mathrm{pC} \mathrm{i} / \mathrm{L}$ & 28.2 & 1.3 \\
Gross beta, $\mathrm{pC} \mathrm{i} / \mathrm{L}$ & 49 & 11 \\
Chromium (total), ug/L & 110 & 1,740 \\
Nitrate (as $\mathrm{NO}_{3}$ ), ug/L & 100,000 & 10,000 \\
\hline
\end{tabular}

The PUREX laboratory analyzed the chromium, gross alpha, gross beta, nitrates, and uranium from the samples with the lowest turbidity after treatment.

Aliquots (400 mL) of water samples from wells 199-H4-4 and 199-D5-15 were placed in $1-L$ beakers. Due to the paucity of sample volume, $400 \mathrm{~mL}$ was used as a test. The solution additions were adjusted accordingly.

The $1-L$ beaker containing $400 \mathrm{~mL}$ of water was placed in the paddle stirrer and the paddle lowered into the water. The speed was adjusted to the maximum rpm available to induce as high a Reynolds number $\left(N_{R}\right)$ as possible.

The ferric chloride was introduced at a concentration of $30 \mathrm{mg} \mathrm{Fe}$ (III)/L via a pipette just under the water surface. (The stock solution was prepared to contain $30 \mathrm{mg}$ of $\mathrm{Fe}$ (III)/mL. Therefore, $1 \mathrm{~mL}$ of stock solution would be added to $1 \mathrm{~L}$ of well water. If less well water was used, the appropriate adjustment to the amount of the stock solution was made.) This aspect of the test represents the rapid mix tank in a physicochemical water treatment system. The ferric chloride was allowed to mix for 2 minutes.

After 2 minutes, the paddles were slowed to $20 \mathrm{rpm}$ and the CAT-FLOC L was introduced just under the water surface. To ascertain the treatment regime that allowed the lowest turbidity to be obtained, the CAT-FLOC was varied from $1 \%$ to $4 \%$ against $30 \mathrm{mg} \mathrm{Fe}$ (III)/L. The CAT-FLOC was allowed to contact the ferric chloride induced pin-floc for 2 minutes. This aspect of the test represents the flocculation basin in a physicochemical water treatment system.

After 2 minutes of contact, the paddles were stopped and removed from the water. The floc was allowed to settle, and turbidity, $\mathrm{pH}$, and solids measurements were made.

The test water was also filtered through a 0.2 -micron filter to retain all flocculated material. The samples sent to the PUREX laboratory consisted of the well water without treatment, the flocculated material, and the filtrate.

The test and sample preparation data are recorded in laboratory notebook WHC-N-321 1 (Herting 1993). 


\subsubsection{Quality Control}

These tests were not done in duplicate, nor were replicate analyses performed. Analytical standards were run, and all standards were within acceptable limits.

\subsubsection{Results} samples.

Table 5 contains the results of the physical measurements from the water

The floc generated, settled within 10 to 15 minutes and exhibited compression settling. By visual observation, the floc appeared to dewater easily when filtered.

The settleability of the floc was determined in a $1-L$ graduated cylinder under the ferric chloride and CAT-FLOC conditions that gave the best response to the turbidity measurement.

A liter of well water sample was introduced into a liter-graduated cylinder (approximately 14- by $2.25-$ in. ID) with a magnetic stir bar and placed on a magnetic stirrer. The ferric chloride and CAT-FLOC was introduced into the sample with the appropriate mixing times as described above. After the CAT-FLOC had contacted the pin-floc for 2 minutes, the stirrer was turned off and the floc was allowed to settle. Measurements were taken of the heavy floc line at 1-minute intervals (Table 6). The measurements were stopped at 10 minutes as the resident time in a clarification basin is usually 15 minutes or more. By 10 minutes, the floc would have cleared the outflow weir inlets in the clarification tank.

As stated above, the chemical analysis was conducted at PUREX laboratory. Table 7 gives the results.

\subsection{ANION EXCHANGE METHODS}

Strong-base anion exchange has been used in a number of applications to remove chromate from corrosion inhibition solutions used in water-cooled heat exchange equipment and to remove nitrate from nitrate-polluted waters.

Strong-base anion exchange also has been used successfully in uranium milling operations, as well as to remove U(VI) from contaminated Hanford Site groundwater. Therefore, three strong-base anion exchange resins were tested for their efficiency and capacity in removing the three contaminants (chromate, uranium, and nitrate) from Hanford Site groundwater. The three resins were selected for these applications on the recommendations of the resin manufacturers, Rohm and Haas Company and Dow Chemical Company. 
Table 5. Physical Response Parameters.

\begin{tabular}{|c|c|c|c|c|c|}
\hline $\begin{array}{c}\text { Wel1 } \\
\text { sample }\end{array}$ & $\begin{array}{c}\text { Turbidity } \\
\text { before } \\
\text { treatment } \\
\text { (NTU) }\end{array}$ & $\begin{array}{c}\text { Turbidity } \\
\text { after } \\
\text { treatment } \\
\text { (NTU) }\end{array}$ & $\begin{array}{c}\mathrm{pH} \text { before } \\
\text { treatment }\end{array}$ & $\begin{array}{c}\mathrm{pH} \text { after } \\
\text { treatment }\end{array}$ & $\begin{array}{c}\text { Solids } \\
\text { generated } \\
(\mathrm{g} / \mathrm{L})\end{array}$ \\
\hline H4-4 & 3.2 & 1.1 & 7.4 & 6.5 & 0.821 \\
D5-15 & 1.0 & 1.0 & 7.1 & 5.8 & 0.660 \\
\hline
\end{tabular}

Table 6. Distance of Floc Line from Top of Water.

\begin{tabular}{|c|c|c|}
\hline Time (minutes) & We11 D5-15 (in.) & We11 H4-4 (in.) \\
\hline 1 & 0.5 & 0.5 \\
2 & 1.25 & 1.0 \\
3 & 2.0 & 2.25 \\
4 & 3.0 & 3.25 \\
5 & 3.75 & 4.25 \\
6 & 4.25 & 5.5 \\
7 & 5.75 & 6.75 \\
8 & 7.0 & 7.5 \\
9 & 8.0 & 8.25 \\
10 & 9.25 & 9.75 \\
\hline
\end{tabular}

Table 7. Chemical Analysis.

\begin{tabular}{|c|c|c|c|c|c|}
\hline We $11^{a}$ & $\begin{array}{c}\text { Gross } \\
\text { alpha } \\
(\mathrm{pC} \mathrm{i} / \mathrm{L})\end{array}$ & $\begin{array}{c}\text { Gross } \\
\text { beta } \\
(\mathrm{pC} \mathrm{i} / \mathrm{L})\end{array}$ & $\begin{array}{c}\text { Total } \\
\text { chromium } \\
(\mathrm{ppb})\end{array}$ & $\begin{array}{c}\text { Uranium } \\
(\mathrm{ppb})\end{array}$ & $\begin{array}{c}\text { Nitrate } \\
(\mathrm{ppb})\end{array}$ \\
\hline $\mathrm{H} 4-4 \mathrm{C}$ & $<48$ & $<1,900$ & 67 & 35 & 61,000 \\
$\mathrm{H} 4-4 \mathrm{~F}$ & 57 & 270 & 30 & $<0.97$ & 61,000 \\
$\mathrm{H} 4-4 \mathrm{Pl}$ & $<936$ & $<2,800$ & 510 & 207 & $b$ \\
$\mathrm{D} 5-15 \mathrm{C}$ & 56 & 75 & 2,250 & 4 & 5,030 \\
$\mathrm{D} 5-15 \mathrm{~F}$ & $<61$ & $<401$ & 1,340 & $<0.97$ & 5,060 \\
$\mathrm{D} 5-15 \mathrm{P}$ & $<1,500$ & 23,100 & 55,500 & $<0.97$ & $\mathrm{~b}$ \\
\hline
\end{tabular}

$P=$ floc.

'The precipitate was dissolved in nitric acid and rendered unusable for nitrate analysis. 
WHC-SD-ER-DTR-001, Rev. 0

\subsection{BATCH TESTS}

\subsubsection{Experimental}

The anion exchange tests were conducted in much the same manner as the precipitation tests previously mentioned, to facilitate comparisons between the precipitation and anion exchange methods. The levels of resin used in all batch tests were approximately $6 \mathrm{~g} / 30 \mathrm{~mL}$ and $1.2 \mathrm{~g} / 30 \mathrm{~mL}$ of solution. The centrifugation step was deleted, the resin beads did not pack, and a filtration step was sufficient to remove all the beads. The resins were approximately 16-30 mesh in size.

The test was a full factorial experiment, which means that all combinations of the variables of interest (uranium, nitrate, chromium, and resin concentration) were explored. Each variable had two levels, which yield eight different solution compositions and two different levels of rasin, for a total of 16 tests per resin. Blanks and standards were shipped witn each batch of samples. Because of the small amount of sample per test, no replicate analyses were done.

\subsubsection{Quality Control}

All anion exchange batch tests were done in duplicate. Method blanks and standards were sent with each batch of samples. Analytical quality control (performed at PUREX Laboratory) included standards with every batch run, for all the analyses. All standards fell within acceptable $( \pm 20 \%$ relative standard deviation) limits. No contamination was detected in the method blanks.

\subsubsection{Results}

All of the DFs presented in Table 8 (which summarizes Appendix D) should be considered to be : ow estimates, as the limit of detection is the limiting factor in the DFs. The effects of the limit of detection on the DF are discussed in the previcus section. This effect is pronounced for the uranium DF of Dowex $21 \mathrm{~K}$, as the data for a high initial uranium concentration test are not available and TWO other high initial uranium concentration data points have inflated "less-than" values due to insufficient sample. Reruns for the several different analyses often exhausted the small amount of sample available. The data for low initial amounts of contaminants fail to show any differences among the resins and demonstrate that a limit of detection comparable with the initial concentration yields a low DF.

Jowex $21 \mathrm{~K}$ has a much higher DF for nitrate than the other two resins and comparable chromium DFs. Given the uncertainties in the data (shown as confidence limits), the uranium DF for Dowex $21 \mathrm{~K}$ is comparable with the other two resins. All the resins show excellent DFs for uranium and chromate.

The data do not support more significant figures than shown in Table 8. The data are reported as the mean \pm one standard deviation. 
WHC-SD-ER-DTR-001, Rev. 0

Table 8. Average Decontamination Factors--Anion Exchange Resin Methods High Initial Concentration Decontamination Factors.

\begin{tabular}{|c|c|c|c|c|}
\hline & Uranium & Nitrate & $\begin{array}{c}\text { Total } \\
\text { chromium } \\
\text { by ICP }\end{array}$ & $\begin{array}{c}\text { Chromium } \\
\text { (VI) }\end{array}$ \\
\hline Dowex 21K & $\begin{array}{c}90 \pm 70 \\
(7)^{\mathrm{a}}\end{array}$ & $\begin{array}{c}40 \pm 20 \\
(7)\end{array}$ & $\begin{array}{c}100 \pm 46 \\
(6)\end{array}$ & $\begin{array}{c}90 \pm 12 \\
(4)\end{array}$ \\
\hline Amberlite 410 & $\begin{array}{c}120 \pm 46 \\
(15)\end{array}$ & $\begin{array}{c}12 \pm 2 \\
(7)\end{array}$ & $\begin{array}{c}60 \pm 23 \\
(6)\end{array}$ & $\begin{array}{c}86 \pm 3 \\
(4)\end{array}$ \\
\hline Amberlite 402 & $\begin{array}{c}110 \pm 70 \\
(14)\end{array}$ & $\begin{array}{c}6 \pm 1 \\
(4)\end{array}$ & $\begin{array}{c}40 \pm 23 \\
(6)\end{array}$ & $\begin{array}{c}60 \pm 46 \\
(4)\end{array}$ \\
\hline
\end{tabular}

${ }^{a}$ The numbers in parentheses are the decontamination

factors for low initial amount of contaminants.

Freundlich analysis (a plot of the logarithm of mass of solute adsorbed versus $10 \mathrm{~g}$ effluent concentration) planned in the test procedures (Beck and Delegard 1993) was performed. Regressions showed the data to be inconclusive; therefore, the analysis yielded no useful information. The goal of a Freundlich analys is is to predict the resin loading at $100 \%$ breakthrough (the effluent and initial concentrations are equal) and determine the capacity of the resin in terms of throughput column volumes.

The effect of interactions among the contaminants on the final concentration of the contaminants has been explored using the statistical package Statgraphics (a trademark of Statistical Graphics Corporation). To determine the interactions among the contaminants, Equation 1 was used in a stepwise regression procedure.

The final concentration of contaminant, $C_{f i n a l}$, was modeled using an equation in the form of Equation 1.

$$
\begin{aligned}
C_{\text {final }} & =\text { constant }+B_{1}[\mathrm{U}]+B_{2}[\mathrm{Cr}]+B_{3}\left[\mathrm{NO}_{3}\right]+B_{4}[\text { Resin }] \\
& +B_{12}[\mathrm{U}] *[\mathrm{Cr}]+B_{13}[\mathrm{U}] *\left[\mathrm{NO}_{3}\right]+B_{14}[\mathrm{U}] *[\text { Resin }] \\
& +B_{23}[\mathrm{Cr}] *\left[\mathrm{NO}_{3}\right]+B_{24}[\mathrm{Cr}] *[\text { Resin }]+B_{34}\left[\mathrm{NO}_{3}\right] *[\text { Resin }]
\end{aligned}
$$

The stepwise regression procedure was used to estimate and test the significance of the regression coefficients $B_{1}, B_{2}, \ldots B_{34}$. Appendix $E$ gives the regression coefficients for each of the variables in Equation 1.

The concentrations (e.g., [U]) used in Equation 1 are the initial concentration of each of the contaminants. The interaction terms (e.g., $[\mathrm{U}] *[\mathrm{Cr}])$ are the product of the initial concentrations of the contaminants. In the example used, this is the concentration of uranium multiplied by the concentration of chromium. This equation does not take into account the $\mathrm{Cr}$ (VI) initial concentration as it is essentially identical to the $\mathrm{Cr}$ (Cr-ICP) value. The use of two identical values like the original concentrations of $\mathrm{Cr}$ and $\mathrm{Cr}(V I)$ in the equation would have created computational difficulties. 
WHC-SD-ER-DTR-001, Rev. 0

A positive coefficient denotes a term that increases $C_{\text {final }}$ (decreasing DF) with increasing initial concentration of the interferant. A negative coefficient denotes a term that decreases $C_{\text {final }}$ (increasing DF) with increasing initial concentration of the interferant.

One notable result of the regression analysis is that the final uranium concentration model is free from any interactions with any of the resins, indicating that it is probably the specie most tightly bound to the resin and therefore least likely to break through and most likely to be eluted last. Nitrate has significant interactions with chromium (with Amberlite 402) and with the product of the nitrate and chromium concentrations, with Amberlite 402 and 410 . This indicates that nitrate and chromate may be competing for the same binding sites on Amberlite 402 and 410 . Nitrate and chromium do not interact on Dowex $21 \mathrm{~K}$. A very small coefficient in the nitrate equation for the product of the concentrations of uranium and chromium also exists for Dowex 21k. Nitrate is interfered with by uranium on Amberlite 402 and 410 .

\subsection{EQUILIBRIUM TESTS}

\subsubsection{Introduction}

The Freundlich analyses failed to yield usable information. Therefore, an alternative method was needed to estimate the amount of solution needed to enable the contaminants to reach breakthrough. The removal efficiency $\epsilon$ (given as milliliters of solution treated per milliliters of resin) is the amount of solution that the resin has treated, such that the effluent concentration is $50 \%$ of the original (feed) concentration, per milliliters of resin (Bray 1989).

$$
\begin{aligned}
\epsilon= & (C 0-C f / C f) * \text { sample volume } / \text { resin mass } \\
& \star \text { resin bed density }
\end{aligned}
$$

where $C_{0}$ is the original concentration and $C f$ is the concentration of the contaminant after equilibrium treatment. Sample volume is in units of milliliters, the resin mass in units of grams, and the resin bed density in units of grams per milliliter.

This equation holds true for all reasonable column flow rates (where equilibrium is approximated) (Daniels et a1. 1962).

\subsubsection{Experimental}

The equilibrium tests were conducted similarly to the aforementioned anion exchange batch tests, but included only the solution that had high $U$ $(\sim 500 \mathrm{ppb}), \mathrm{NO}_{3}{ }^{-}(\sim 200,000 \mathrm{npb})$, and $\mathrm{Cr}(\sim 2,000 \mathrm{ppb})$ concentration. The amount of resin used was $0.1 \mathrm{~g} / 30 \mathrm{~mL}$ of solution and $0.05 \mathrm{~g} / 30 \mathrm{~mL}$ solution, 
which is far less than that used in the batch contact tests. The solution was stirred overnight and then treated identically to the batch tests.

\subsubsection{Quality Control}

All tests were done in duplicate. Method blanks and standards were sent with each batch of samples. Analytical quality control (performed at PUREX laboratory) included standards with every batch run, for all the analyses. A11 standards fell within acceptable ( $\pm 20 \%$ relative standard deviation) limits. No contamination was detected in the method blanks.

\subsubsection{Results}

The equilibrium tests showed that an enormous quantity of spiked groundwater would be required to reach breakthrough (a point where the concentration equals $50 \%$ of original concentration, i.e., $C / C 0=0.5)$ for uranium and chromium. The least amount of groundwater needed to achieve breakthrough for chromium is approximately $15 \mathrm{~L}$ of spiked groundwater per milliliter of resin. Because the minimum amount of resin is $4.6 \mathrm{~mL}$, due to constraints on column size, this would require about $70 \mathrm{~L}$ of spiked groundwater. This amount of groundwater was not available and, even if it were, it would exceed the physical limits of the fume hood where the tests were conducted. The value given for the volume required for the effluent concentration to reach $50 \%$ of the influent concentration is in fact a minimum, as this equilibrium test, like the batch tests, was limited by the limit of detection of the chemical analysis for both chromium and uranium.

The raw data and some calculated values are presented in Appendix F.

\subsection{BREAKTHROUGH TESTS}

The four main objectives of performing breakthrough tests are as follows.

- Determine whether the resin will adsorb the contaminants sufficiently in a column with a realistic flow rate.

- Determine the effect, if any, flow rate has on the column retention of contaminants. This is done by running the column at both the low and high end of the manufacturer's suggested flow rates.

- Determine the number of column volumes of groundwater the column can retain, without breakthrough, of each of the contaminants.

- Determine, using actual groundwater from the $100-\mathrm{H}$ and 100-D Areas, the behavior of the contaminants on the column. 


\subsection{EXPERIMENTAL}

The breakthrough tests on the spiked groundwater (from well 199-H3-2C and spiked to approximately $800 \mathrm{ppb} \mathrm{U}, 2,000 \mathrm{ppb} \mathrm{Cr}$, and $200,000 \mathrm{ppb} \mathrm{NO}_{3}$ ) were run to approximately 2,000 column volumes, instead of the test procedure plan of running to breakthrough. The change from the test procedures (Beck and Delegard 1993) was due to the fact that the Freundlich analyses were not usable. An alternative method ("equilibrium tests" suggested by Lane Bray) used to determine the breakthrough capacity of the column suggested that the number of required column volumes to achieve uranium or chromium breakthrough would exceed the amount of groundwater available for spiking. Two thousand column volumes is sufficient to demonstrate whether the estimates for breakthrough are realistic and, in any case, there is insufficient sample to run a larger number of column volumes through the column. The "confirmatory" tests on the unspiked samples were run by running all available samples (wells 199-H4-4, 199-D5-15, and biodenitrified 199-H4-4, 199-D5-15 mix) through the column and measuring the effluent for contaminants. The unspiked groundwaters were not expected to show breakthrough for uranium, due to the limited amount of sample (several liters for each), the low concentration of uranium, and the very high DFs of the resin for uranium.

The column volume for all breakthrough tests was approximately $4.85 \mathrm{~mL}$, which corresponds to $4.18 \mathrm{~g}$ of damp, conditioned resin. The term "column volume" as used in this report denotes the volume of the resin bed, including interstitial water, but does not include the headspace in the column above the resin bed. The column volume of $4.85 \mathrm{~mL}$ was chosen to give the column a height-to-diameter ratio of $5 \mathrm{~cm}$ to $1 \mathrm{~cm}$, while maintaining a diameter wide enough to avoid wall effects (i.e., channeling at the wall). The tests on spiked groundwater were run at two different flow rates: $\sim 16$ column volumes per hour $(\sim 80 \mathrm{~mL} / \mathrm{h})$ and 27 column volumes per hour $(\sim 160 \mathrm{~mL} / \mathrm{h})$. The approximate value of the flow rate is due to the inaccuracies of the pumps used, as these flow rates were very close to the minimum flow rates of which the pumps were capable. The flow rates were chosen to bracket the manufacturer's recommended flow rate for Dowex $21 \mathrm{~K}$ resin. The column was loaded downflow for all breakthrough tests.

The "confirmatory" tests on the unspiked samples were run by feeding all available samples through the column at the "low" (16 column volumes per hour) flow rate and measuring the effluent for contaminants. The unspiked groundwaters were not expected to show breakthrough for uranium, due to the limited amount of sample (several liters for each) and the very high DFs of the resin for uranium. Also included in the "confirmatory" category is groundwater from wel1s 199-H4-4 and 199-D5-15 that had been biodenitrified by using native Hanford microbial populations at Pacific Northwest Laboratory.

To determine actual breakthrough volumes, a very highly spiked solution (199-H3-2C spiked to 6,580 ppb chromium, 5,920 ppb chromate, 2,840 ppb uranium, and $194,200 \mathrm{ppb} \mathrm{NO}{ }_{3}^{-}$) test was run. This test was run with approximately $11 \mathrm{~L}$ of solution and a flow rate of about 16 column volumes per hour.

The flow rate for the later tests is quite variable because the metering pump used originally quit permanently and the replacement peristaltic pump was set at its lowest setting. No attempt was made to control the effluent $\mathrm{pH}$ or 
WHC-SD-ER-DTR-001, Rev. 0

the temperature, although the temperature was moderated by building heating and ventilation controls.

To ensure that each actual groundwater (either 199-D5-15 or 199-H4-4) sample was homogeneous throughout the test, the groundwater which was contained in several bottles was mixed in the original (as-recieved) containers.

\subsection{QUALITY CONTROL}

Method blanks and standards were sent with each batch of samples for the breakthrough tests. Analytical quality control (performed at PUREX laboratory) included standards with every batch run, for all the analyses. All standards fell within acceptable ( $\pm 20 \%$ relative standard deviation) limits. No contamination was detected in the method blanks.

\subsection{RESULTS AND DISCUSSION}

The value $\mathrm{C} / \mathrm{C}_{0}$ is a measure of the efficiency of the column in removing the contaminant (Table 8 ). The plot of $C / C_{0}$ versus column volume is most useful for the high spiked solution, showing that Dowex $21 \mathrm{~K}$ removes the high concentration of contaminants down to the level of detection for several hundred column volumes. For the unspiked solutions, the plot of concentration versus column volumes is the most informative; it shows directly the effect of the actual groundwater on the column's ability to remove the contaminants to below the performance goals. The plot of $\mathrm{C} / \mathrm{Co}$ versus column volumes for unspiked groundwater can be confusing, due to the fact that if the original concentration ( $\mathrm{CO}$ ) is small, the value of $\mathrm{C} / \mathrm{Co}_{0}$ becomes highly scattered because of analytical uncertainties near the limit of detection. The plot $\mathrm{C} / \mathrm{Co}$ versus column volumes is included for comparison purposes only. A log scale on the $y$ axis ( $C / C o$ or concentration) is used to ensure that all data points are seen clearly, as the concentrations of nitrate and the other contaminants often differ by several orders of magnitude.

\subsubsection{Low Flow Rate, Spiked Groundwater}

The low flow rate, spiked groundwater $[199-\mathrm{H} 3-2 \mathrm{C}$, spiked to $\mathrm{Co}=700 \mathrm{ppb}$ uranium, 1,770 ppb chromium(VI), 2,020 ppb total chromium (chromium by ICP), and $192,300 \mathrm{ppb} \mathrm{NO}{ }_{3}^{-}$] results are presented in Appendix G.

The data show that even 1,800 column volumes are insufficient to show breakthrough for uranium. The data appear scattered because of the neardetection level concentrations and the log scale on the $C / C_{0}(y)$ axis.

Chromium concentrations at 1,800 column volumes are near the performance level and are only about $3 \%$ to $4 \%$ of the original concentration. The slight increase (from the detection level) in chromium concentration at high column volumes is consistent with a gradual slope to the breakthrough curve.

Nitrate shows $50 \%$ breakthrough at approximately 350 column volumes (about $1,700 \mathrm{~mL}$ ), which corresponds to a resin loading of $1.1 \mathrm{meg} / \mathrm{mL}$ of wet conditioned resin. This loading is very close to the theoretical capacity of $1.2 \mathrm{meq} / \mathrm{mL}$ for the resin Dowex $21 \mathrm{~K}$. The number of column volumes treated at 
breakthrough is consistent with that value calculated from the equilibrium test data.

The carbonate concentration in this test solution was approximately $115 \mathrm{ppm}$, assuming that this test solution was identical to a different sample of low spiked groundwater (with the same contaminant spike level).

\subsubsection{High Flow Rate Spiked Groundwater}

The fast flow test was performed on water from well 199-H3-2C that was spiked to initial concentrations of $820 \mathrm{ppb}$ uranium, 2,100 ppb chromium, $1,990 \mathrm{ppb}$ chromate, and $212,700 \mathrm{ppb} \mathrm{NO}_{3}^{-}$.

The flow rate averaged roughly two times that of the slow flow test, while roughly the same concentration of contaminants was spiked into the well water as for the slow flow tests. The pump essentially destroyed itself during the course of the test, ending it prematurely. The flow rate inconsistencies can be seen in Appendix $H$.

Chromium showed no breakthrough tendencies during this abbreviated test.

Uranium data show a slightly higher concentration of uranium in the effluent than the slow flow test demonstrated. This may indicate that the kinetics of uranium adsorption are slow. However, the uranium concentration was always below the project performance goal for uranium.

The carbonate concentration in this test solution was approximately $115 \mathrm{ppm}$ [assuming that this test solution was identical to a different sample of low spiked groundwater (with the same contaminant spike level)].

\subsubsection{Well 199-H4-4 Unspiked Groundwater}

This (199-H4-4) well water had an original (before treatment) concentration of $49 \mathrm{ppb}$ uranium, $65.5 \mathrm{ppb}$ chromate, $79.4 \mathrm{ppb}$ total chromium, and $84,600 \mathrm{ppb} \mathrm{NO}{ }^{\circ}$.

Neither uranium, chromium, nor chromate showed any signs of breakthrough.

Nitrate broke through (defined as $C=0.5^{*}$ Co) at 390 or 445 column volumes, depending on how the breakthrough curve is interpreted. The spike at 390 column volumes could be an analytical outlier or could reflect the actual concentration of nitrate. $169 \mathrm{ppm}$.

The carbonate concentration in this test solution was approximately

The graphs and data can be found in Appendix $H$. 
WHC-SD-ER-DTR-001, Rev. 0

\subsubsection{Well 199-D5-15 Unspiked Groundwater}

The results of the breakthrough tests with unspikeu groundwater D5-15 [with an original concentration of $12 \mathrm{ppb}$ uranium, 1,930 ppb chromium(VI), $2,025 \mathrm{ppb}$ total chromium, and $49,700 \mathrm{ppb} \mathrm{NO}{ }_{3}^{-}$] are presented below. The data and graphical representations of the data for this test can be found in Appendix $\mathrm{J}$.

The nitrate is initially adsorbed onto the column and reaches breakthrough at about 450 column volumes.

Both uranium and chromium show good retention. Chromium rises above the performance goal ( $100 \mathrm{ppb}$ ) much sooner (about 1,100 column volumes) than expected from the 199-H3-2C spiked groundwater results, indicating some interference from components in the groundwater. However, $4 \%$ is a minimal (within experimental error) difference in the chromium concentration. The decontamination levels are essentially identical, as most of the variation in the D5-15 test comes from concentrations barely above the method detection limit (29 ppb total chromium, $19 \mathrm{ppb}$ chromium +6 ). Uranium values are highly scattered, probably because they (and the initial uranium concentration) are very close to the detection level. The carbonate concentration of this test solution is approximately $100 \mathrm{ppm}$.

\subsubsection{Biodenitrified Groundwater}

Biodenitrified water, a treated mix (approximately $50 \% / 50 \%$ from wells H4-4 and D5-15), had a concentration prior to treatment, of $1,000 \mathrm{ppb}$ total chromium, $735 \mathrm{ppb}$ chromate, $10 \mathrm{ppb}$ uranium, and $10,900 \mathrm{ppb} \mathrm{NO}_{3}{ }^{-}$. As shown in Appendix $K$, Figures $K-1$ and $K-2$, this sample is unusual in that nitrate breakthrough occurs at 740 column volumes. Note that the breakthrough volume is only about twice the breakthrough volume of the other tests, which typically had an initial concentration of nitrate over 15 times that of the biodenitrified groundwater. Uranium and chromium show no signs of breakthrough, the effluent concentrations being at the detection level throughou the test. The behavior of the contaminants was consistent with the other tests, given the initial contaminant levels. The flow rate for this test was quite variable.

The carbonate concentration of th:s test solution is approximately $166 \mathrm{ppm}$. The biodenitrified water also had a slightly above-background reading of total organic carbon, which is consistent with the biodenitrification process.

\subsubsection{Very High Spiked Groundwater, Low Flow Rate}

The highly spiked groundwater consisted of water from well 199-H3-2C, spiked to $6,580 \mathrm{ppb}$ chromium, 5,920 ppb chromate, 2,840 ppb uranium, and $194,200 \mathrm{ppb} \mathrm{NO}_{3}^{-}$. The chromium values are significantly higher than the values reported for chromate. The high concentration of chromium on the anion exchange resin may be leading to a partial reduction in valance state of chromate. The chromate never reaches breakthrough $\left(C / C_{0}=0.5\right)$ but does exceed the performance goals in a relatively small number of column volumes. 
The initial concentration of chromium is three times higher than the highest expected in 100 Area wells.

Uranium does exceed the performance goals for several samples scattered throughout the latter half of the test. No discernable breakthrough trend can be observed. The higher flow rate seems to coincide with the higher uranium concentrations in the treated effluent. It should be noted that the flow rate is a 5-h average; therefore, the actual maximum or minimum flow rates could be much higher or lower.

This test demonstrates that Dowex $21 \mathrm{~K}$ has a very high affinity for uranium. The initial uranium concentration of the test solution was about 10 times higher than that expected for actual groundwater. The concentration of carbonate in the test solution is approximately $115 \mathrm{ppm}$ (assuming that the carbonate concentration is similar to that of the low spiked groundwater). Graphs and tables of the data for this test can be found in Appendix $L$.

\subsubsection{Total Alpha and Total Beta Analyses}

Total alpha and total beta analyses were performed on a select few samples, due to the large effort involved in performing these analyses. Total alpha and total beta are the regulatory analyses of concern (DOE-RL 1993). Samples were generated by compositing. The two samples of starting solution were composited together, while the treated effluent samples were generated by compositing the first half of the same breakthrough run together and compositing the second half of the same breakthrough run together.

The total alpha and total beta results can be compared to uranium values in the appendices for the corresponding breakthrough run. Assumptions can be made that all the alpha activity is due to uranium, while the total beta is due to the immediate daughter products of ${ }^{238} \mathrm{U}\left({ }^{234} \mathrm{Th}\right.$ and $\left.{ }^{234} \mathrm{~Pa}\right)$. The uranium (as determined by fluorescence spectrophotometry) agrees reasonably well with the value of uranium derived frim the total alpha content.

The most noteworthy item is that all the treated samples were below the method limits of detection. Because of the very low values of these samples and counting statistics, the limits of detection ranged from $36 \mathrm{pC} i / \mathrm{L}-27 \mathrm{ppb}$ uranium to $258 \mathrm{pCi} / \mathrm{L}-188 \mathrm{ppb}$ uranium for total beta and $14 \mathrm{pCi} / \mathrm{L}-20 \mathrm{ppb}$ uranium to $227 \mathrm{pCi} / \mathrm{L}-330 \mathrm{ppb}$ uranium. The values for the starting solutions are given in Table 9.

The fact that the total beta levels for several starting solution samples do not match the uranium levels may be due to the daughters $\left({ }^{234} \mathrm{Th}\right.$ and ${ }^{234} \mathrm{~Pa}$ ) plating out on the sides of the container, or perhaps the assumption of secular equilibrium is invalid. 
WHC-SD-ER-DTR-001, Rev. 0

Table 9. Values for Starting Solutions.

\begin{tabular}{|l|l|c|c|c|c|}
\hline $\begin{array}{c}\text { Sample } \\
\#\end{array}$ & \multicolumn{1}{|c|}{ Sample description } & $\begin{array}{c}\text { Total } \\
\text { alpha } \\
(\mathrm{pC} \mathrm{i} / \mathrm{L})\end{array}$ & $\begin{array}{c}\text { Uraniuma } \\
(\mathrm{ppb})\end{array}$ & $\begin{array}{c}\text { Total } \\
\text { beta } \\
(\mathrm{pC} \mathrm{i} / \mathrm{L})\end{array}$ & $\begin{array}{c}\text { Uraniumb } \\
(\mathrm{ppb})\end{array}$ \\
\hline ERK29B1 & H4-4 breakthrough test & $<73$ & $<110$ & 424 & 308 \\
\hline ERK19B1 & D5-15 breakthrough test & $<90$ & $<65$ & $<145$ & $<105$ \\
\hline ERK31F1 & $\begin{array}{l}\text { Hiah flow rate spiked } \\
\text { H3-2C breakthrough test }\end{array}$ & 320 & 470 & 380 & 280 \\
\hline ERK31L1 & $\begin{array}{l}\text { Low flow rate spiked } \\
\text { H3-2C breakthrough test }\end{array}$ & 360 & 530 & 430 & 320 \\
\hline ERK30B1 & $\begin{array}{l}\text { Biodenitrified (H4-4, } \\
\text { D5-15) breakthrough test }\end{array}$ & $<165$ & $<240$ & $<230$ & $<110$ \\
\hline ERK41B1 & $\begin{array}{l}\text { High spiked H3-2C } \\
\text { breakthrough tests }\end{array}$ & 1630 & 2370 & 1905 & 1390 \\
\hline CK31Z1 & Cycling test & 360 & 530 & $<308$ & $<224$ \\
\hline
\end{tabular}

${ }^{a}$ Assuming all alpha is natural uranium.

${ }^{b}$ Assuming that the total beta is due solely to ${ }^{234} \mathrm{Th}$ and ${ }^{234} \mathrm{~Pa}$ in secular equilibrium with uranium.

The total beta for sample ERK29B1 (199-H4-4) is greater than expected, given the less-than level of total alpha (and therefore of uranium). This implies that the total beta value is the result of some beta emitter not associated with the uranium decay chain. This beta emitter could be technetium, which is known to be in 100-HR-3 groundwater (DOE-RL 1993). Regardless of the identity of the beta emitter(s), the ion exchange treatment removes it, as the treated water samples for the H4-4 breakthrough test are below the limit of detection ( $<90 \mathrm{pC} i / L$ is the highest limit of detection for these samples).

\subsubsection{Common Themes in the Breakthrough Results}

The nitrate breakthrough was remarkably constant, given the amount of variance in the initial concentrations of the various anions. A correlation matrix was developed that showed no strong correlations (given uncertainties in the data) between the nitrate breakthrough volume and any independent variable. The independent variables included the initial concentrations of chloride, sulfate, nitrate, and carbonate (as total inorganic carbon). Other independent variables included the flow rate; the range of the flow rate; the average temperature; the range of the temperature; the average $\mathrm{pH}$; the range of the $\mathrm{pH}$; and the products of the concentrations of carbonate and sulfate, carbonate and chloride, carbonate and nitrate, and the sum of the concentrations of carbonate, chloride, nitrate, and sulfate. The chloride and sulfate concentration values were taken from the raw data for ion chromatography (the method for nitrate). The chloride and sulfate data do not have standards associated with them because these analyses were not originally requested. The strongest correlation that does exist is the negative $\left(R=-0.73, R^{2}=0.53\right)$ 
WHC-SD-ER-DTR-001, Rev. 0

correlation between the initial nitrate concentration and nitrate breakthrough.

An interesting feature of the nitrate breakthrough curve is that the nitrate concentration in the effluent from the column after breakthrough is higher than the original concentration. The spike in the nitrate breakthrough curve, where the nitrate concentration exceeds that of the initial concentration, implies that some mechanism other than simple breakthrough is taking place. An explanation of this phenomenon could be that another anion could be "pushing" the nitrate off the resin, so that the nitrate eluted by the other anion is added to the nitrate passing right through the column, thus producing the hump in the breakthrough curve. Uranyl tricarbonate anion is not a likely candidate for the "nitrate pushing" anion, since the extremely low amount of uranium in the groundwater precludes it from binding all active sites on the resin and thereby affecting the other anions. Chromate's concentration compared to nitrate is so low that chromate probably is not the responsible anion for the nitrate elution. It is interesting that, despite the fact that the nitrate concentration in the test solutions varies by a factor of 20 , the nitrate elution varies by only a factor of 2 . Carbonate (as bicarbonate at the $\mathrm{pH}$ of these groundwaters) is probably the specie responsible for the nitrate elution and the odd shape of the elution curve. Nonetheless, the carbonate hypothes is is not supported by the previously discussed statistical analysis of the data. A possible reason for this is that the carbonate concentration in all the test solutions (spiked and unspiked well water) is very similar, destroying any correlation.

\subsection{CYCLING TEST}

The primary purpose of the cycling tests is to determine the frequency and amounts of eluant and wash solutions needed. These parameters are determined by examining the elution curve (concentration of eluate versus column volume). The efficiency of washing will also be ascertained. A secondary goal was to determine if the resin can undergo many cycles of use. To accomplish this, the column underwent 10 cycles of loading, elution, and washing.

\subsection{EXPERIMENTAL}

The general method used was that of the test procedures (Beck and Delegard 1993), except that the sample was loaded downflow and eluted and washed upflow. This change was made to ensure that channeling did not occur in the small resin bed that was used. The test was run for 10 cycles. Elution and washing for the cycling tests was performed after $19 \mathrm{~h}$ of loading at approximately $1.2 \mathrm{~mL} / \mathrm{min}(15$ bed vol $/ \mathrm{h})$, a treated water sample volume of approximately 300 column volumes. Three hundred column volumes was chosen as the duration of the loading cycle, since this is a point prior to nitrate breakthrough. The solution used is approximately the same concentration as used for the slow and fast spiked 199-H3-2C tests [676 ppb U, 2,225 ppb total chromium, 1,780 ppb chromium (VI), 203,000 ppb N03', and 3,000 $\mathrm{ppb} \mathrm{Cl}^{-}$]. 
WHC-SD-ER-DTR-001, Rev. 0

The first elution was done at a flow rate that the authors thought was too high, as the eluant stirred the column and had a broad elution front. The experimental apparatus was also thought to be inadequate, because there was about $14 \mathrm{~mL}$ of deadspace from the top of the resin bed to the eluate catch bottle. The tubing that exited the column was changed from $1 / 8$-in.-ID to 1/16-in.-ID tubing to eliminate $10 \mathrm{~mL}$ of deadspace. The elution flow rate was decreased by a factor of 4 (to $1.25 \mathrm{~mL} / \mathrm{min}$ ) to eliminate the disruptive effect of the higher flow rate and allow time for the contaminants to be removed from the column into the eluate.

An additional step was added to the wash procedure. The pump was stopped about halfway through the wash and the beads were allowed to settle. The pump was then restarted and the beads circulated throughout the column. At the end of washing, some density gradients (indicating concentrated sodium chloride solutions) were noted for each cycle. Washing does not seem to have been complete, and some excess chloride appears to have remained on the column. The final wash fractions were observed to be colorless, or very lightly colored. The wash flow rate for all cycles through 10 was approximately $9 \mathrm{~mL} / \mathrm{min}$ (upflow).

Cycles 2 through 10 were run with the changed apparatus and flow rate.

The eluate was gathered as one sample $(\sim 22 \mathrm{~mL})$ for cycles 2 through 9. The wash was also gathered as one sample $(\sim 20 \mathrm{~mL})$ for cycles 2 through 9. This is in contrast to the first and tenth cycles, in which the eluate was split into $10(\sim 2 \mathrm{~mL})$ samples and the wash was split into $4(\sim 5 \mathrm{~mL})$ samples. This was done to minimize the number of samples submitted, maximizing analytical turnaround time.

\subsection{RESULTS}

The results of the cycling tests (see Appendix $M$ for tables and graphs) are broken up by type of sample, i.e., treated effluent or eluate or wash. The reason for this is the widely different concentrations for the different types of samples. It should be remembered, however, that the chronological order of the samples is "effluent," "eluate," and "wash," followed by the next "effluent" sample for the next cycle. The eluate and wash graphs are presented as a line graph, so each point is one analysis (of duplicates). The eluate and wash data points are in the order generated. The XY method of plotting versus column volumes would have bunched up the first and tenth cycle results, so a line graph was used. Because the effluent concentration graph is presented as an XY graph, some closely spaced duplicates may appear to be one point. The effluent data are plotted versus the total number of column volumes of spiked 199-H3-2C run through the column.

\subsubsection{Treated Effluent}

The contaminant concentrations in the test jolution after ion exchange treatment (hereafter referred to as "treated effluent") are below the performance goals, except for uranium for the last eight cycles. The spike seen in the total chromium data at about 600 column volumes is considered to be an analytical outlier, as the chromate data do not show this drastic increase in the concentration. The value of the outlier is one order of magnitude higher 
than the surrounding values, leading to the conclusion that these points are outliers. Nitrate concentrations are all below the performance goal. A small upward trend in nitrate concentrations may be evident in the last two treated effluent samples, but the data are not clear. Both total chromium and chromate are well below the performance goal, with a possible downward trend near the end of the test.

Uranium was not completely removed from the test solution for cycles 3 through 10. Some samples of treated effluent water contained as much as $100 \mathrm{ppb}$ uranium. This could be caused by either the wash being incomplete or uranium flowing directly into the effluent sample bottle upon the start of sample loading. This hypothesis is supported by the presence of significant quantities of uranium in the last wash samples.

The upflow wash method, which stirred the beads in the column, could have deposited beads incompletely stripped of uranium close to the bottom of the column. Beads at the bottom of the column could have released uranium into the treated effluent, without the benefit of beads below them to readsorb the uranium.

Alternatively, the column simply was not adsorbing a portion of the incoming uranium from the test solution bottle. A small fraction of the anion exchange sites could be those specific for uranium binding, and this small fraction could be overloaded, leaving sites more weakly binding for uranium. This hypothesis is not supported by the breakthrough tests, because the total amount of uranium adsorbed during the breakthrough tests was much greater than the amount run through during a few cycles of the cycling test. However, this hypothesis is supported by trending and consistency of the concentration, as the washing process would not likely be that consistent.

Another explanation would be the formation of $\mathrm{UO}_{2} \mathrm{Cl}_{2}$, a highly soluble neutral compound, during washing, by chloride displacement of carbonate from the uranyl triscarbonato anion.

Despite the above performance level concentrations of uranium, it should be noted that the method always removed six-sevenths of the uranium in $676 \mathrm{ppb}$ uranium spiked groundwater. Given the typical uranium concentrations in actual Hanford Site groundwater $(<100 \mathrm{ppb})$, a removal of six-sevenths of the uranium would meet the performance goal for uranium used in this report.

\subsubsection{Eluate}

The elution of chromium (total and chromate), uranium, and nitrate is accomplished by the introduction of a $4 \mathrm{M}$ sodium chloride solution onto the column bed.

Contaminant concentrations in the eluate are typically several hundred thousand $\mathrm{ppb}$ chromium, ten million ppb nitrate, and thirty thousand ppb uranium. The initial breakthrough of the contaminants is followed by the appearance of chloride in the eluate. This behavior of the chloride concentration is expected, as the chloride must displace the contaminants from the resin before the chloride itself dilutes. 
The average percent recovered (based on the amount loaded during each cycle and ignoring any residual) for the 10 elutions is $74 \pm 49 \%$ of the uranium, $99 \pm 66 \%$ total chromium, $94 \pm 37 \%$ chromium (VI), and $71 \pm 42 \%$ nitrate. The uncertainties are given as the $95 \%$ confidence limits. The high uncertainties in the percent recoveries are largely due to the low recovery during the first cycle.

\subsubsection{Wash}

The contaminant concentration in the wash was significantly lower than in the eluate. The contaminant concentration did not reach a level comparable to the original test solution, even during the final wash sample. This indicates that the elution was not complete. The chloride (the eluant) concentration was not reduced to near zero, indicating that the wash was not entirely successful. However, despite the incompleteness of the elution and wash, the contaminant level in the treated effluent is quite low, as previously discussed.

The average percent recovered (based on the amount loaded during each cycle and ignoring any residual) for the 10 washes is $18 \pm 32 \%$ of the uranium, $16 \pm 33 \%$ total chromium, $13 \pm 29 \%$ chromium (VI), and $20 \pm 31 \%$ nitrate. The uncertainties are given as the $95 \%$ confidence limits. The large uncertainties are probably due to the high recovery values for the first cycle, as the contaminants not removed with the eluate "bleed" over into the wash portion of the cycle.

\subsubsection{Common Themes}

Statistical analysis (a correlation matrix) of the whole cycling test data set revealed strong correlations between the concentrations of the contaminants. No strong correlation between the contaminant concentrations and chloride (the eluant) concentration is seen. The lack of correlation betweein the eluant and contaminant concentrations could be caused by a number of factors. The treated effluent concentrations of all the species of interest were steady throughout the tests. The chloride concentrations would be expected to lag behind the contaminant concentrations, as chloride would be adsorbed on the resin as it displaced the contaminant.

The average total (eluate and wash) percent recovered (based on the amount loaded during each cycle and ignoring any residual) for the 10 cycles is $92 \%$ of the uranium, $116 \%$ total chromium, $107 \%$ chromium (VI), and $85 \%$ nitrate. The uncertainty in these numbers is roughly equivalent to the uncertainty in the corresponding eluate and wash values.

\subsection{DISCUSSION AND CONCLUSIONS}

This section gives conclusions from the tests and presents suggestions for the groundwater treatment method. The reasons uranium was chosen as the radionuclide to be treated are discussed. Technetium removal (which was not included in the tests) is discussed, with references to the literature. 
WHC-SD-ER-DTR-001, Rev. 0

\subsection{URANIUM}

Uranium was chosen as the radionuclide(s) to be tested for removal from Hanford Site groundwaters. Although by itself it is not a contaminant of concern (DOE-RL 1993, Section 1.3), uranium is a contributor to both the gross alpha and the gross beta. The uranium contribution to the gross alpha activity is primarily by way of ${ }^{238} \mathrm{U}$ and ${ }^{234} \mathrm{U}$ (about $98 \%$ of the activity of natural uranium). Uranium contribution to the gross beta activity is by way of the ${ }^{238} \mathrm{U}$ daughter products, ${ }^{234} \mathrm{~Pa}$ and ${ }^{234} \mathrm{Th}$. The combined activity of these two daughters is twice that of the ${ }^{238} \mathrm{U}$ parent, which means that their beta activity is comparable (in the number of decay events) to the uranium alpha activity. Removing the uranium parent also removes the daughter product activity, after the daughter products already formed have decayed away (a process that takes about a half of a year) (Negin 1990). Therefore, decreasing the uranium concentration in the groundwater will have a significant impact on gross alpha and beta levels and will, in most probability, bring them within performance limits.

\subsection{TECHNETIUM}

Technetium was not chosen as a radionuclide to be tested for removal. Although it is present in the groundwater, technetium contributes approximately $6 \%$ its beta to the gross beta measurement. This is due to the low energy beta that it produces. The proposed limit from the U.S. Environmental Protection Agency, July 18, 1991, Federal Register (Vol. 56, No. 138, p. 33120) for ${ }^{99} \mathrm{TC}$ is $3,790 \mathrm{pCi} / \mathrm{L}$ (4 mrem/year exposure) for groundwater. However, the suggested anion exchange remediation technique may also work for this radionuclide, since technetium is in the form of pertechnetate $\left(\mathrm{TCO}_{4}^{-}\right)$in many groundwaters. This idea is supported by the 1iterature (Del Cul et al. 1993, Anders 1960). Both sources describe the adsorption of technetium (as pertechnetate) to strong base anion exchange resins of the quaternary ammonium type as being very tight. Elution of pertechnetate anion from these resins is only accomplished by high concentrations of powerful eluants (such as perchloric acid) (Anders 1960) and/or reductants (Korkish 1989, p. 19). Given these properties of technetium, it may prove possible to elute nitrate, chromium, and uranium from the resin while retaining technetium. The removal of technetium could be an added value to using the anion exchange method. Del Cul et al. (1993) also describe the use of iron fillings to reduce and precipitate technetium, but state that the speed of technetium removal is slow in very dilute- (groundwater) type solutions.

\subsection{BATCH TESTS}

\subsubsection{Precipitation Methods}

Neither precipitation method (sodium sulfide/ferrous sulfate, phosphate/calcium chloride) is suitable for the purposes of this project, since neither removes both metals (uranium and chromium). However, the test procedure (Beck and Delegard 1993) states that one of the precipitation methods will undergo confirmatory testing. Other researchers worked on optimizing (Duncan 1993) the use of cation flocculating agents with these 
precipitating agents and additional precipitating agents as well. Because the work specified by Duncan (1993) is a complementary effort to the work planned in Beck and Delegard (1993), no further work was done in this area by the principal investigator. This change in work scope was agreed to by the customer. The difficulty of removal of the precipitants and prelimary calculations of the cost of sludge disposal resulted in the decision to terminate further tests of the precipitation methods.

From the precipitation bench-scale tests, the following was determined.

- Physical Conditions-- The samples were tested at ambient temperature and $\mathrm{pH}$. The ferrous sulfate/sodium sulfide and the phosphate/calcium chloride tests had little effect on the final pH of the solution. The ferric chloride did change the $\mathrm{pH} 0.9$ units for well H4-4 and 1.3 units for well D5-15. This would be expected since the iron is in the plus three valance state and would attract three hydroxyl units and thus decrease the $\mathrm{pH}$ (see Section 2.4 and Appendix $(-1)$.

- What is the Optimum Removal Chemistry--

For the sodium sulfide and ferrous sulfate tests, the sodium sulfide was introduced to the test solution to obtain a final concentration of $12 \mathrm{mg} \mathrm{s} .2 / \mathrm{L}$. The ferrous sulfate was introduced to the test solution to obtain a final concentration of $9.9 \mathrm{mg}$ $\mathrm{Fe}^{+2} / \mathrm{L}$.

For the phosphate/calcium chloride tests, the sodium hydrogen phosphate was introduced to the test solution to obtain a final concentration of $5,550 \mathrm{mg} \mathrm{HPO}_{4}^{-2} / \mathrm{L}$. The calcium chloride was added to obcain a final concentration of $92 \mathrm{mg} \mathrm{Ca}^{+2} / \mathrm{L}$ (to include the amount of calcium present in the solution).

For the ferric chloride precipitation tests in conjunction with the polymeric flocculent aid, CAT-FLOC $L$, the ferric chloride was added to the test solution so that the final concentration of iron was $30 \mathrm{mg} \mathrm{Fe}+\mathrm{L}$ and the CAT-FLOC $\mathrm{L}$ introduced (see Sections 2.2, 2.3, and 2.4).

- Reaction Rates--The rates are reported in Table 6 . As may be determined from the data, a curvelinear response is given. However, the flocculent fell over 9 in. within 10 minutes. The resulting sludge was stable and easily dewaterable.

- Effects of Feed Variability and Presence of Other Contaminants (such as nitrates)--The feed of the chemicals followed standard water treatment practices (Hudson). Nitrates did not show any interference with the coagulation/precipitation tests (see Section 2.3).

- Biodentrification Process Interference--Due to the process of reduction/precipitation adding chemicals to a treatment train, biodenitrification would occur as the last step. 
WHC-SD-ER-DTR-001, Rev. 0

- Performance Levels for Chromium and Radionuclides--Removal did not demonstrate the efficacy that was required or that demonstrated by the ion exchange (see Sections 2.3 and 2.4).

\subsubsection{Anion Exchange Resins}

As the anion exchange resins were evaluated as a standalone treatment, Dowex $21 \mathrm{~K}$ was used for confirmatory testing and cycling tests. The lack of interaction of nitrate (except the product of the nitrate and resin concentrations; see Appendix ()) was an added attraction to the use of Dowex $21 \mathrm{~K}$.

From the anion exchange resin evaluation, the following was determined.

- Pretreatment Requirements--There were no pretreatment requirements identified in the treatability tests. In the field, it is recommended that a prefilter (such as a spiral wound, polypropylene, 5-micron nominal) be used before the ion exchange unit to filter out extraneous material (well casing material, etc.).

- Optimum Resin for Site Contaminants--From the results of the treatability tests, the resin that was found to be most efficacious was the Dowex $21 \mathrm{~K}$, a strong base anion exchange resin.

- Effect of Resin Loading on Contaminant Removal--A synopsis of results reported elsewhere (Sections 3.1.3, 4.3.3, and 4.3.4), indicate that

- No breakthrough was observed in well H4-4 (except for nitrates at $445 \mathrm{CV}$ ); the concentrations introduced were nitrate at $84,600 \mathrm{ppb}$, uranium (VI) at $49 \mathrm{ppb}$, chromate at $65.5 \mathrm{ppb}$, and total chromium at $79.4 \mathrm{ppb}$.

- For well D5-15, the concentrations introduced were nitrate at $49,700 \mathrm{ppb}$, uranium (VI) at $12 \mathrm{ppb}$, chromate at $1,930 \mathrm{ppb}$, and total chromium at 2,025 ppb. Breakthrough was observed at $450 \mathrm{CV}$ for nitrate and 1,100 CV for chromium. The chromium was introduced at 2,025 ppb and breakthrough occurred at $100 \mathrm{ppb}$. Therefore, 1,925 ppb was taken up by the ion exchange resin. The test ion exchange column was approximately $1 \mathrm{~mL}$ of Dowex $21 \mathrm{~K}$ resin. The density of the Dowex $21 \mathrm{~K}$ resin is $431 \mathrm{~b} / \mathrm{ft}^{3}$ or $689 \mathrm{mg} / \mathrm{mL}$. The capacity of the resin for 05-15 translates into $1925 \mu \mathrm{g} / \mathrm{mL}$ divided by the resin density, which yields $2.79 \mu \mathrm{g}$ chromium per milligram of resin.

- Effect of Multiple Cycles on Resin Life--No degradation of the resin was noted on the resin life (see Section 6.7).

- Quality of Effluent Produced--During the multiple cycles, the contaminant concentrations are below the performance goals, with the exception of uranium (VI) for the last eight cycles (see Section 5.2.1). 
- Composition of Regenerate (Including Rinse) Produced--The ion exchange is eluded by the introduction of $4 M$ sodium chloride onto the column bed. The contaminate concentrations in the eluate are typically several hundred thousand ppb chromium, ten million ppb nitrate, and thirty thousand ppb uranium. The rinse (wash) contained contaminant concentrations that were significantly lower than the values found in the eluate (see Sections 5.2 .2 and $5.2 .3)$.

- Volume of Regenerant (Including Rinse) Produced--The resin is eluted with 4 to $5 \mathrm{CVs}$ of $4 \mathrm{M}$ sodium chloride. The rinse (wash) produces one to two column volumes of liquid. It should be noted here that both the eluate and the rinse will contain uranium (VI) and is a mixed waste.

\subsection{FERRIC CHLORIDE/COAGULANT AID TESTS}

It was beyond the scope of this effort to optimize the parameters of ferric chloride/CAT-FLOC to the contaminants of concern. Rather, it was to demonstrate the efficacy of ferric chloride along with a polymeric flocculant aid in removing uranium (and to thereby reduce gross alpha and gross beta counts) and chromium.

The gross alpha and gross beta counts have shown an increase in the flocculant as opposed to the filtrate. The values were at detection limit; strong conclusions should not be readily arrived at, except that there appeared to be an effect.

The uranium showed mixed results between D5-15 and H4-4. On sample D5-15, the gross beta appears to have been concentrated (filtrate to flocculant), while the uranium does not appear to have been affected. However, on sample $\mathrm{H} 4-4$, the uranium appears to have been concentrated in the flocculant.

Overall, the ferric chloride appeared to have the effect of concentrating the uranium (chromium is yet to be determined). The CAT-FLOC enabled the ferric chloride pin-floc to precipitate and clarify the water. The sludge produced by the ferric chloride/CAT-FLOC combination appears to dewater effectively.

The combination of ferric chloride and a flocculant aid (such as the CAT-FLOC) is an efficacious methodology in the treatment and clarification of groundwater with similar matrices.

\subsection{EQUILIBRIUM TESTS}

These tests showed that the adsorption potential of Dowex 21K for uranium and chromate was far higher than the amount of groundwater available for spiking. The resin adsorbed uranium and chromium far more strongly than it did nitrate. These tests clearly showed that nitrate would be the limiting factor in the use of the resin. 
WHC-SD-ER-DTR-001, Rev. 0

\section{6 BREAKTHROUGH TESTS}

Dowex $21 \mathrm{~K}$ shows very high affinity for uranium and chromium and a substantial affinity for nitrate. The nitrate loading on the resin varies from close to the theoretical loading capacity of the resin to much less. Nitrate adsorption seems to be governed by the presence of other (non-chromium or uranium) anions. Regression analys is of the breakthrough volumes versus the initial concentration of nitrate, sulfate, chloride, the $\mathrm{pH}$, and the product of the concentrations of nitrate and sulfate was performed. No significant relationship between the breakthrough volume and the other variables could be determined. The anion most likely to be the cause of the nitrate breakthrough volume is bicarbonate, which is known to be the dominant anion in Hanford Site groundwater. The nitrate loading had no effect on the adsorption of chromium or uranium.

\subsection{CYCLING TESTS}

The cycling tests demonstrated that chloride partially elutes the contaminants of interest. No degradation of the resin or its performance was noted (except in the case of uranium removal). The amount of eluant solution and wash solution does not seem sufficient to completely strip the resin of contaminants. Performance goals were met for nitrate, total chromium, and chromium (VI). The performance goal for uranium was met for the first two cycles. The failure to meet the performance goal for the last eight cycles may not be that serious, because Hanford Site groundwater typically has less than one-eighth of the concentration of uranium in the test solution. The high number of column volumes $(<2,000$ for chromium and uranium) treated, which is a measure of cleanup efficiency, should also be noted.

\subsection{RECOMMENDATIONS}

The results of this series of tests suggest that the most efficacious method for removal of nitrate, chromium [as chromate, chromium (VI)], and uranium is anion exchange with a strong base ion exchange resin.

Loading of the contaminants onto the resin and disposing of the resin may be the most cost-effective means of removing chromate and uranium from the groundwater. This approach would also be the best method for technetium removal due to the difficulties in eluting technetium.

If nitrate removal is desired, loading of the contaminants onto the resin column followed by elution of the contaminants from the resin and reuse of the resin would be the best process.

From the resins tested, Dowex $21 \mathrm{~K}$ has been demonstrated to be a strong candidate for pilot-scale testing. The Dowex $21 \mathrm{~K}$ was orginally developed for the acid mine tailings associated with uranium mining. The concentrations encountered were much higher than that encountered in the Hanford groundwater. Therefore, much of the information that was obtained from Dow Chemical Company was directly related to the uranium mine tailings for uranium recovery. Experience with Dowex $21 \mathrm{~K}$ indicates a stable resin with a long service 1 ife for the uranium mining industry. 
A field pilot-scale ion exchange unit using Dowex $21 \mathrm{~K}$ resin is recommended. The suggested unit would entail the following:

Specific issues that should be studied during the pilot-scale operation would include confirmation of the amount of column volumes to attain the performance levels for chromium. Also, a total water analys is should be completed on both the influent and effluent (hydraulic residence time taken into consideration) on either a monthly or biweekly time table.

\subsection{REFERENCES}

Anders, E., 1960, The Radiochemistry of Technetium, NAS-NS-3021, U.S. Atomic Energy Commission, Washington, D.C.

Beck, M. A., 1992, Process Chemistry Support 4, Controlled Laboratory Notebook, WHC-N-120 8, Westinghouse Hanford Company, Richland, Washington.

Beck, M. A. and C. H. Delegard, 1993, Test Procedures - Treatment Tests for Ex Situ Removal of Chromate, Nitrate, and Uranium (VI) from Hanford Groundwater, WHC-SD-EN-TC-003, Rev. 1, Westinghouse Hanford Company, Richland, Washington.

Bray, L. A., 1989, PNL Test Procedure LAB-1, Rev. 0, Pacific Northwest Laboratory, Richland, Washington.

Daniels, F., J. W. Williams, P. Bender, R. A. Alberty, and C. D. Cornwell, 1962, Experimental Physical Chemistry, page 308, 6th edition, McGrawHill Book Company, New York, New York.

Del Cul, G. D., W. D. Bostick, D. R. Trotter, and P. E. Osborne, 1993, "Technetium-99 Removal from Process Solutions and Contaminated Groundwater", Separation Science and Technology, Vol. 28, No. 1-3, pp. 551-564, Marcel Dekker, New York.

DOE-RL, 1993, 100-HR-3 Groundwater Treatability Test Plan, DOE/RL-92-73, Rev. O, U.S. Department of Energy, Richland Operations Office, Richland, Washington.

Duncan, J. B., 1993, Internal memo to J. R. Jewett, Request for Laboratory Space and Support, Westinghouse Hanford Company, Richland, Washington.

Herting, D. L., 1993, Process Chemistry Support, Controlled Laboratory Notebook, WHC-N-321 1, Westinghouse Hanford Company, Richland, Washington.

Hudson, H., 1981, Water Clarification Processes -- Practical Design and Evaluation, Van Nostrand Reinhold Company, New York, New York.

IT Corp., 1989, Fernald Operable Unit \#6 Groundwater Treatability Test Results, Appendix F Project \#303317.26.05, August 29, 1989, Knoxville, Tennessee. 
Korkish, J., 1989, Handbook of Ion Exchange Resins and Their Applications to Inorganic Analytical Chemistry, Volume V, CRC Press, Boca Raton.

Negin, C, 1990, RADDECAY Version 3, Grove Engineering, Rockville, Maryland.

Raman, M., 1981, "Polymers to Clear Water," CHEMTECH, April 1981, pp. 252-255.

Sawyer, C. and P. McCarty, 1978, Chemistry for Environmental Engineering, McGraw-Hill Book Company, New York, New York.

Weber, W. J., 1972, Physicochemical Processes for Water Quality Control, John Wiley and Sons, New York, New York.

WHC, 1988, Environmental Compliance Manual, WHC-CM-7-5, Westinghouse Hanford Company, Richland, Washington. 


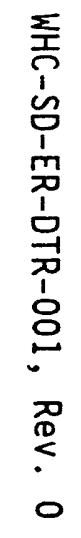


WHC-SD-ER-DTR-001, Rev. 0

APPENDIX A

CONCENTRATION VALUES ANALYTICAL BLANK AND SAMPLE 199-H3-2C 
WHC-SD-ER-DTR-001, Rev. 0

A-2 
WHC-SD-ER-DTR-001, Rev. 0

Table A-1. Analytical Blank Values.

\begin{tabular}{|c|c|}
\hline Analyte & $\begin{array}{l}\text { Concentration (in } \\
\text { ppb unless otherwise } \\
\text { specified) }\end{array}$ \\
\hline $\mathrm{cr} 6$ & $<56.7$ \\
\hline$U$ & $<4.73$ \\
\hline TIC & 48000 \\
\hline TOC & 6000 \\
\hline F- & $<100$ \\
\hline$C L-$ & $<100$ \\
\hline NO2- & $<1000$ \\
\hline NO3- & $<1000$ \\
\hline P04- & $<1000$ \\
\hline SO4- & $<1000$ \\
\hline Al & $<51$ \\
\hline As & 50 \\
\hline $\mathrm{Ca}$ & $<5$ \\
\hline $\mathrm{Cr}$ & $<15$ \\
\hline$K$ & $<275$ \\
\hline $\mathrm{Mg}$ & $<3$ \\
\hline $\mathrm{Na}$ & 44 \\
\hline$P$ & $<70$ \\
\hline$S$ & $<39$ \\
\hline $\mathrm{Si}$ & $<34$ \\
\hline Sr & $<3$ \\
\hline V & $<11$ \\
\hline$W$ & $<36$ \\
\hline
\end{tabular}


WHC-SD-ER-DTR-001, Rev. 0

Table A-2. Concentration Values for 199-H3-2C. (sheet 1 of 2)

\begin{tabular}{|c|c|}
\hline Analyte & $\begin{array}{l}\text { Concentrations (in } \\
\text { ppb unless otherwise } \\
\text { specified) }\end{array}$ \\
\hline $\mathrm{Cr}+6$ & 70.2 \\
\hline $\mathrm{Cr}+6$ & 70.2 \\
\hline $\mathrm{pH}$ & 8.3 \\
\hline $\mathrm{pH}$ & 8.25 \\
\hline TIC & 35000 \\
\hline TIC & 38000 \\
\hline TOC & $<5500$ \\
\hline TOC & $<5500$ \\
\hline TOT-ACT & $<50000 \mathrm{pCi} / \mathrm{L}$ \\
\hline$U$ & 5.59 \\
\hline$U$ & 5.59 \\
\hline F- & 319 \\
\hline F- & 306 \\
\hline $\mathrm{Cl}-$ & 2960 \\
\hline $\mathrm{Cl}-$ & 3058 \\
\hline NO2- & $<1000$ \\
\hline $\mathrm{NO2-}$ & $<1000$ \\
\hline NO3- & 3974 \\
\hline NO3- & 4040 \\
\hline PO4- & $<1000$ \\
\hline PO4- & $<1000$ \\
\hline SO4- & 20933 \\
\hline SO4- & 21169 \\
\hline$B$ & 10.9 \\
\hline $\mathrm{Ba}$ & 10.4 \\
\hline $\mathrm{Ca}$ & 24200 \\
\hline $\mathrm{Ca}$ & 23800 \\
\hline $\mathrm{Cr}$ & 27.2 \\
\hline$k$ & 4590 \\
\hline$k$ & 4650 \\
\hline
\end{tabular}




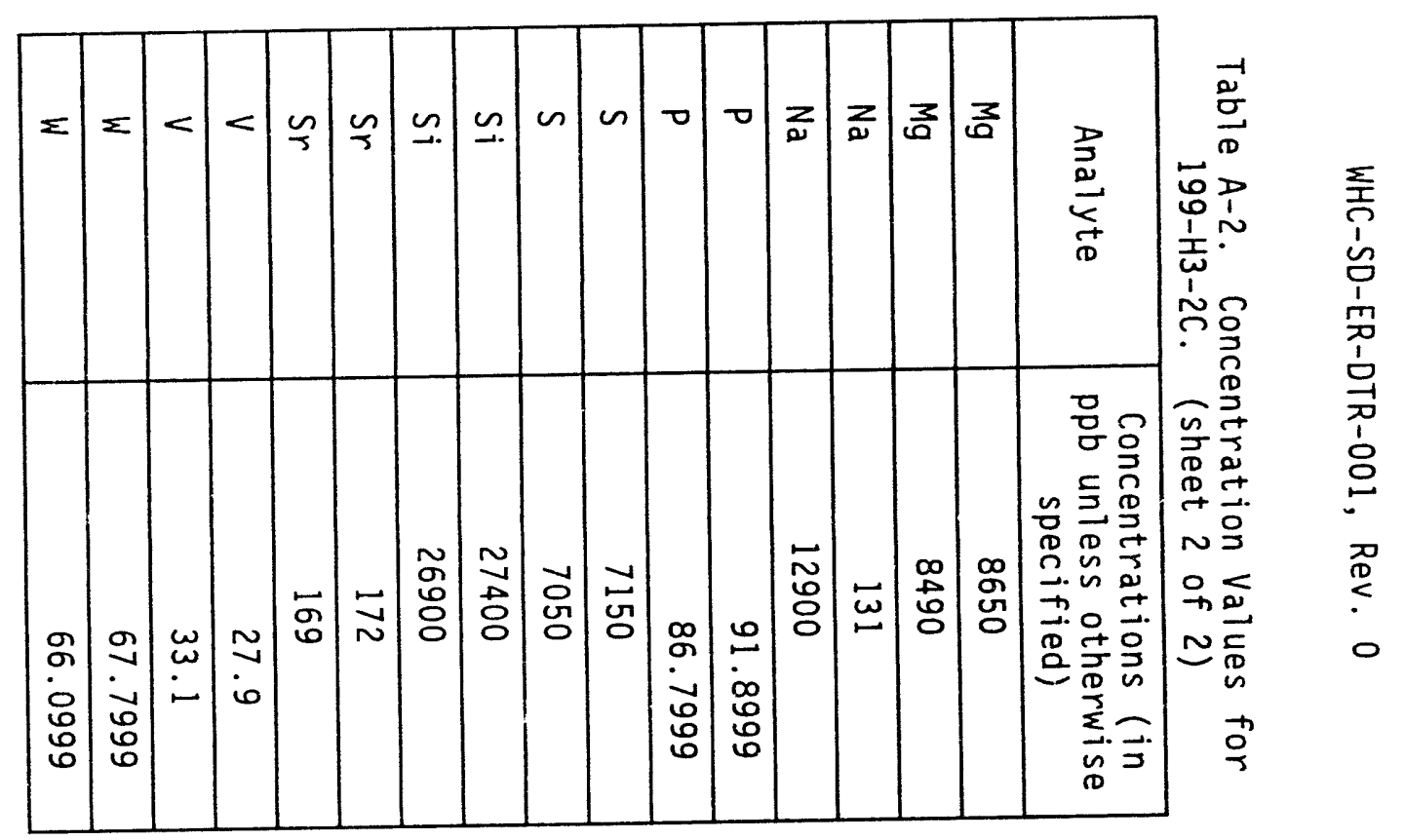


WHC-SD-ER-DTR-001, Rev. 0 
WHC-SD-ER-DTR-001, Rev. 0

APPENDIX B

FILTER METHOD TEST DATA

B-1 


\begin{tabular}{|l|c|c|c|c|c|c|c|c|c|c|}
\hline Sample \# & U & $\begin{array}{c}\text { U } \\
\text { after } \\
\text { test }\end{array}$ & $\begin{array}{c}\text { Total } \\
\text { chromium }\end{array}$ & $\begin{array}{c}\text { Total } \\
\text { chromium } \\
\text { after } \\
\text { test }\end{array}$ & $\mathrm{Cr}(\mathrm{VI})$ & $\begin{array}{c}\mathrm{Cr}(\mathrm{VI}) \\
\text { after } \\
\text { test }\end{array}$ & $\mathrm{N03}$ & $\begin{array}{c}\mathrm{N} 03 \\
\text { after } \\
\text { test }\end{array}$ & $\mathrm{pH}$ & $\begin{array}{c}\mathrm{pH} \\
\text { after } \\
\text { test }\end{array}$ \\
\hline EF0D1101 & 786 & 737 & 220 & 90 & 204 & 222 & 190 & 193 & 7.38 & 8.03 \\
\hline EFOS1101 & 524 & 714 & 222 & 242 & 204 & 224 & 197 & 190 & 7.29 & 8.05 \\
\hline
\end{tabular}

NOTE: All values are given in parts per billion and are not rounded. 
WHC-SD-ER-DTR-001, Rev. 0

\section{APPENDIX C}

RAW DATA FROM THE SODIUM SULFIDE-FERROUS SULPHATE PRECIPITATION BATCH TEST AND 
WHC-SD-ER-DTR-001, Rev. 0 


\begin{tabular}{|l|r|r|r|r|r|r|r|r|r|r|}
\hline SAMPLE \# & $U$ & $\begin{array}{c}\text { U after } \\
\text { test }\end{array}$ & $\begin{array}{c}\text { Total } \\
\text { chromium }\end{array}$ & $\begin{array}{c}\text { Total } \\
\text { crromium } \\
\text { after } \\
\text { test }\end{array}$ & Cr(VI) & $\begin{array}{c}\text { Cr(VI) } \\
\text { after } \\
\text { test }\end{array}$ & NO3 & $\begin{array}{c}\text { NO3 after } \\
\text { test }\end{array}$ & $\begin{array}{c}\text { pH } \\
\text { pH after } \\
\text { test }\end{array}$ \\
\hline EBSD2401 & 52 & ND & 2000 & 172 & 1925 & 19.4 & 6257 & 6068 & 8.41 & 8.74 \\
\hline EBSS2401 & 52 & ND & 2000 & 278 & 1925 & 19.4 & 6257 & 6115 & 8.39 & 8.77 \\
\hline EBSD2301 & 32.8 & 29.7 & 1895 & 44 & 1865 & 19.4 & 192800 & 188200 & 8.4 & 8.69 \\
\hline EBSS2301 & 32.8 & 40 & 1895 & 116 & 1865 & 19.4 & 192800 & 182200 & 8.4 & 8.32 \\
\hline EBSD2201 & 504 & ND & 1920 & 211 & 2050 & 19.4 & 6519 & 6305 & 8.33 & 8.32 \\
\hline EBSS2201 & 504 & 714 & 1920 & 246 & 2050 & ND & 6519 & 6317 & 8.5 & 8.35 \\
\hline EBSD2101 & 536 & 679 & 1895 & 176 & 2050 & 19.4 & 195750 & 193500 & 8.49 & 8.38 \\
\hline EBSS2102 & 536 & ND & 1895 & 35 & 2050 & 19.36 & 195750 & 189200 & 8.55 & 8.32 \\
\hline EBSD1801 & 37.45 & 43.3 & 75.99 & 22 & 81.6 & 19.4 & 70130 & 6890 & 8.35 & 8.44 \\
\hline EBSS1801 & 37.45 & 44.1 & 75.99 & 31 & 81.6 & 19.4 & 70130 & 6750 & 8.05 & 8.48 \\
\hline EBSD1701 & 126.2 & 47.4 & 79.49 & 22 & 82.29 & 20.7 & 187600 & 194100 & 7.81 & 8.29 \\
\hline EBSS1701 & 126.2 & 43.8 & 79.49 & 22 & 82.29 & 20.7 & 187600 & 195200 & 7.83 & 8.27 \\
\hline EBSD1601 & 613.5 & 412 & 80.5 & 22 & 79.5 & 22 & 6653 & 13290 & 8.16 & 8.63 \\
\hline EBSS1601 & 613.5 & 469 & 80.5 & 21 & 79.5 & 20.7 & 6653 & 6550 & 8.05 & 8.58 \\
\hline EBSD1501 & 536 & 526 & 73.99 & 16 & 83.65 & 20.7 & 185750 & 197700 & 7.81 & 8.51 \\
\hline EBSS1501 & 536 & 235 & 73.99 & 11 & 83.65 & 19.4 & 185750 & 207300 & 7.82 & 8.62 \\
\hline
\end{tabular}

1. All values are given in parts per billion and are not rounded.

2. All "0" values are due to insufficient sample and were not used in calculating DFs. 


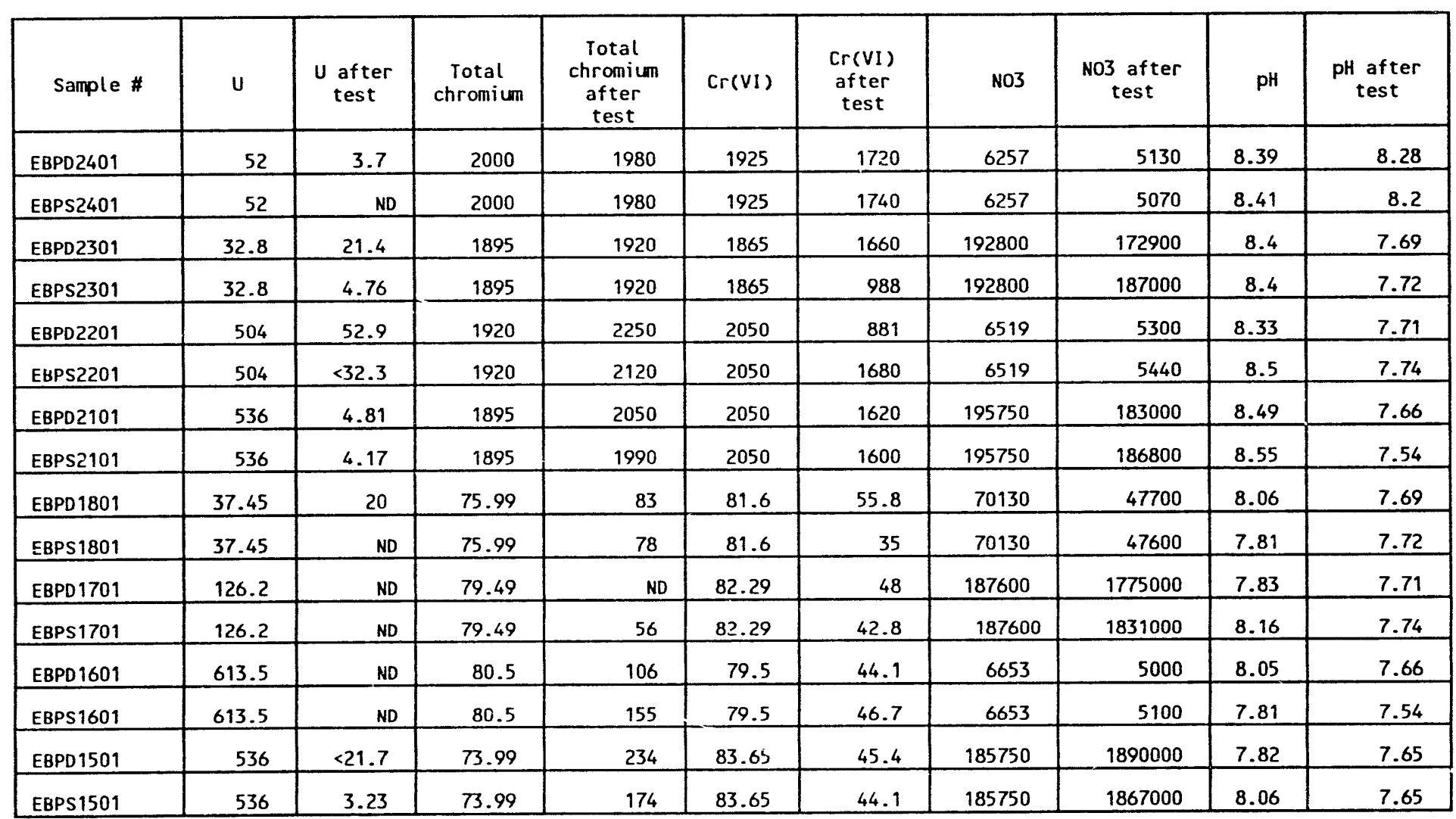

NOTES:

1. All values are given in parts per billion and are not rounded.

2. All "ND" (No Data) values are due to insufficient sample and were not used in calculating DFs. 
WHC-SD-ER-DTR-001, Rev. 0

Table C-3. Raw Data from the Phosphate Scoutiing Tests

(Phosphate Treatment Without Added Calcium Chloride).

\begin{tabular}{|l|c|c|c|c|c|c|}
\hline Sample \# & $\begin{array}{c}\text { U after } \\
\text { test }\end{array}$ & $\begin{array}{c}\text { Total } \\
\text { chromium } \\
\text { after } \\
\text { test }\end{array}$ & $\begin{array}{c}\text { Cr(VI) } \\
\text { after } \\
\text { test }\end{array}$ & $\begin{array}{c}\text { NO3 after } \\
\text { test }\end{array}$ & $\begin{array}{c}\text { PH } \\
\text { after } \\
\text { test }\end{array}$ & $\begin{array}{c}\text { Treatment (evel } \\
\text { (mg Na2HPO4/L } \\
\text { solution treated) }\end{array}$ \\
\hline EBT11010 & 716 & 189 & 186 & 186000 & 7.4 & $\begin{array}{l}\text { * Standard } \\
\text { No treatment }\end{array}$ \\
\hline EBT1102a & 1100 & 202 & 196 & 189000 & 7.3 & $\begin{array}{l}\text { * Standard } \\
\text { No treatment }\end{array}$ \\
\hline EBPS1101 & $108 C$ & 206 & 149 & 186400 & 7.8 & 423 \\
\hline EBPD1102 & 314 & 206 & 175 & 191000 & 7.8 & 423 \\
\hline EBPS1102 & 794 & 202 & 178 & 190000 & 7.6 & 84 \\
\hline EBPD1102 & 1210 & 198 & 170 & 188000 & 7.6 & 84 \\
\hline EPBS1103 & 857 & 198 & 169 & 189000 & 7.6 & 17 \\
\hline EPBD1103 & 722 & 203 & 171 & 188000 & 7.6 & 17 \\
\hline EBPS1104 & 1130 & 205 & 169 & 162000 & 7.6 & 3.4 \\
\hline EPBD1104 & 639 & 200 & 169 & 185000 & 7.6 & 3.4 \\
\hline
\end{tabular}

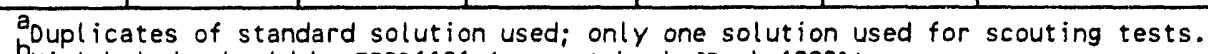

bislabeled; should be EBPD 1101 (per notebook [Beck 1992]). 


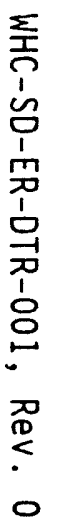


WHC-SD-ER-DTR-001, Rev. 0

\section{APPENDIX D}

RAW DATA FROM ANION RESIN BATCH TESTS 
WHC-SD-ER-DTR-001, Rev. 0

D-2 


\begin{tabular}{|l|r|r|r|r|r|r|r|r|r|}
\hline $\begin{array}{c}\text { Resin: } \\
\text { Dowex 21K }\end{array}$ & \multicolumn{2}{|c|}{ Concentrations (in ppb) of contaminants before and after treatment with Dowex 21K } \\
\hline Sample \# & $\begin{array}{c}\text { U } \\
\text { original }\end{array}$ & $\begin{array}{c}\text { U } \\
\text { after } \\
\text { test }\end{array}$ & $\begin{array}{c}\text { Total } \\
\text { chromium }\end{array}$ & $\begin{array}{c}\text { Total } \\
\text { chromium } \\
\text { after } \\
\text { test }\end{array}$ & Cr(VI) & $\begin{array}{c}\text { Cr(VI) } \\
\text { after } \\
\text { test }\end{array}$ & N03 & $\begin{array}{c}\text { N03 } \\
\text { after } \\
\text { test }\end{array}$ & $\begin{array}{c}\text { Grams } \\
\text { resin } \\
\text { per } \\
\text { solution }\end{array}$ \\
\hline EBKD1801 & $37.45^{\text {a }}$ & 4 & 75.99 & 12.7 & 81.6 & 19.4 & 70130 & 2881 & 1.2067 \\
\hline EBKS1801 & 37.45 & 6.67 & 75.99 & 12.7 & 81.6 & 19.4 & 70130 & 2881 & 6.0379 \\
\hline EBKD1701 & 126.2 & 26.3 & 79.49 & 12.7 & 82.29 & 19.4 & 187600 & 7246 & 1.2023 \\
\hline EBKS1701 & 126.2 & ND & 79.49 & 12.7 & 82.29 & 19.4 & 187600 & 3140 & 6.0043 \\
\hline EBKD1601 & 613.5 & 31.3 & 80.5 & 12.7 & 79.5 & 19.4 & 6653 & 2881 & 1.2144 \\
\hline EBKS1601 & 613.5 & 21.7 & 80.5 & 12.7 & 79.5 & 19.4 & 6653 & 2881 & 6.0387 \\
\hline EBKD1501 & 536 & ND & 73.99 & 12.7 & 83.65 & 19.4 & 185750 & 7741 & 1.2104 \\
\hline EBKS1501 & 536 & ND & 73.99 & 20 & 83.65 & 19.4 & 185750 & 2881 & 6.0008 \\
\hline EBKD2401 & 52 & 4 & 2000 & 12.7 & 1925 & 19.4 & 6257 & 2881 & 1.217 \\
\hline EBKS2401 & 52 & 7.14 & 2000 & 32 & 1925 & 28.5 & 6257 & 2881 & 6.021 \\
\hline EBKD2301 & 32.8 & 3.85 & 1895 & 12.7 & 1865 & 22 & 192800 & 7830 & 1.2076 \\
\hline EBKS2301 & 32.8 & 7.14 & 1895 & 30 & 1865 & 20.7 & 192800 & 3500 & 6.0495 \\
\hline EBKD2201 & 504 & 4 & 1920 & 12.7 & 2050 & 19.4 & 6519 & 2880 & 1.2142 \\
\hline EBKS2201 & 504 & 7.14 & 1920 & 31 & 2050 & 19.4 & 6519 & 2880 & 6.0143 \\
\hline EBKD2101 & 536 & 2.62 & 1895 & 18 & 2050 & 19.4 & 195750 & 7630 & 1.2084 \\
\hline EBKS2101 & 536 & 5.56 & 1895 & 40 & 2050 & 19.4 & 195750 & 3440 & 6.019 \\
\hline
\end{tabular}

NOTE: "0" values were used to determine the linear regression coefficients.

${ }^{a}$ All values are given in parts per billion and are not rounded.

"All "ND" (No Data) values are due to insufficient sample and were not used in calculating DFs. 


\begin{tabular}{|c|c|c|c|c|c|c|c|c|c|}
\hline \multicolumn{2}{|l|}{402 resin } & \multicolumn{8}{|c|}{$\begin{array}{c}\text { Concentrations (in ppb) of contaminants before and after treatment with } \\
\text { Amerlite } 402 \text { resin }\end{array}$} \\
\hline Sample \# & U & $\begin{array}{c}U \\
\text { after } \\
\text { test }\end{array}$ & $\begin{array}{l}\text { Total } \\
\text { chromium }\end{array}$ & $\begin{array}{l}\text { Total } \\
\text { chromium } \\
\text { after } \\
\text { test }\end{array}$ & $\operatorname{cr}(V I)$ & $\begin{array}{c}\operatorname{Cr}(V I) \\
\text { after } \\
\text { test }\end{array}$ & N03 & $\begin{array}{l}\mathrm{NO3} \\
\text { after } \\
\text { test }\end{array}$ & $\begin{array}{l}\text { grams } \\
\text { resin } \\
\text { per } 30 \mathrm{~mL} \\
\text { sclution }\end{array}$ \\
\hline EB2D1801 & 37.45 & $20^{\mathrm{a}}$ & 75.99 & 12.7 & 81.6 & 19.4 & 70130 & 2880 & 1.2012 \\
\hline EB2S1801 & 37.45 & 5.26 & 75.99 & 12.7 & 81.6 & 19.4 & 70130 & ND & 6.014 \\
\hline EB2D1701 & 126.2 & 3.57 & 79.49 & 12.7 & 82.29 & 19.4 & 187600 & 25780 & 1.204 \\
\hline EB2S1701 & 126.2 & 4.75 & 79.49 & 12.7 & 82.29 & 19.4 & 187600 & 21380 & 6.0254 \\
\hline EB2D1601 & 613.5 & 3.33 & 80.5 & 12.7 & 79.5 & 9.4 & 6653 & 2880 & 1.2067 \\
\hline EB2S1601 & 613.5 & 4.35 & 80.5 & 12.7 & 79.5 & 19.4 & 6653 & ND & 6.0228 \\
\hline EB2D1501 & 536 & 3.33 & 73.99 & 12.7 & 83.65 & 19.4 & 185750 & 30660 & 1.2071 \\
\hline EB2S1501 & 536 & 4 & 73.99 & 12.7 & 83.65 & 19.4 & 185750 & 27410 & 6.0184 \\
\hline EB2D2401 & 52 & $N D^{b}$ & 2000 & 23 & 1925 & 19.4 & 6257 & ND & 1.1999 \\
\hline EB2S2401 & 52 & ND & 2000 & 155 & 1925 & 101 & 6257 & ND & 6.0592 \\
\hline EB2D2301 & 32.8 & ND & 1895 & 39 & 1865 & 22 & 192800 & 37140 & 1.2101 \\
\hline EB2S2301 & 32.8 & 20 & 1895 & 173 & 1865 & 130 & 192800 & 30040 & 6.0055 \\
\hline EB2D2201 & 504 & 20 & 1920 & 38 & 2050 & 19.4 & 6519 & 2880 & 1.2024 \\
\hline EB2S2201 & 504 & ND & 1920 & 155 & 2050 & 109 & 6519 & ND & 6.0034 \\
\hline EB2D2101 & 536 & 22.7 & 1895 & 52 & 2050 & 23.3 & 195750 & 43780 & 1.2013 \\
\hline EB2S2101 & 536 & 3.91 & 1895 & 59 & 2050 & 122 & 195750 & 40050 & 6.018 \\
\hline
\end{tabular}

NOTE: "ND" values were assumed to be 0 in determining the linear regression coefficients.

${ }^{a} A l l$ values are given in parts per billion and are not rounded.

"All "ND" (No Data) values are due to insufficient sample and were not used in calculating DFs. 


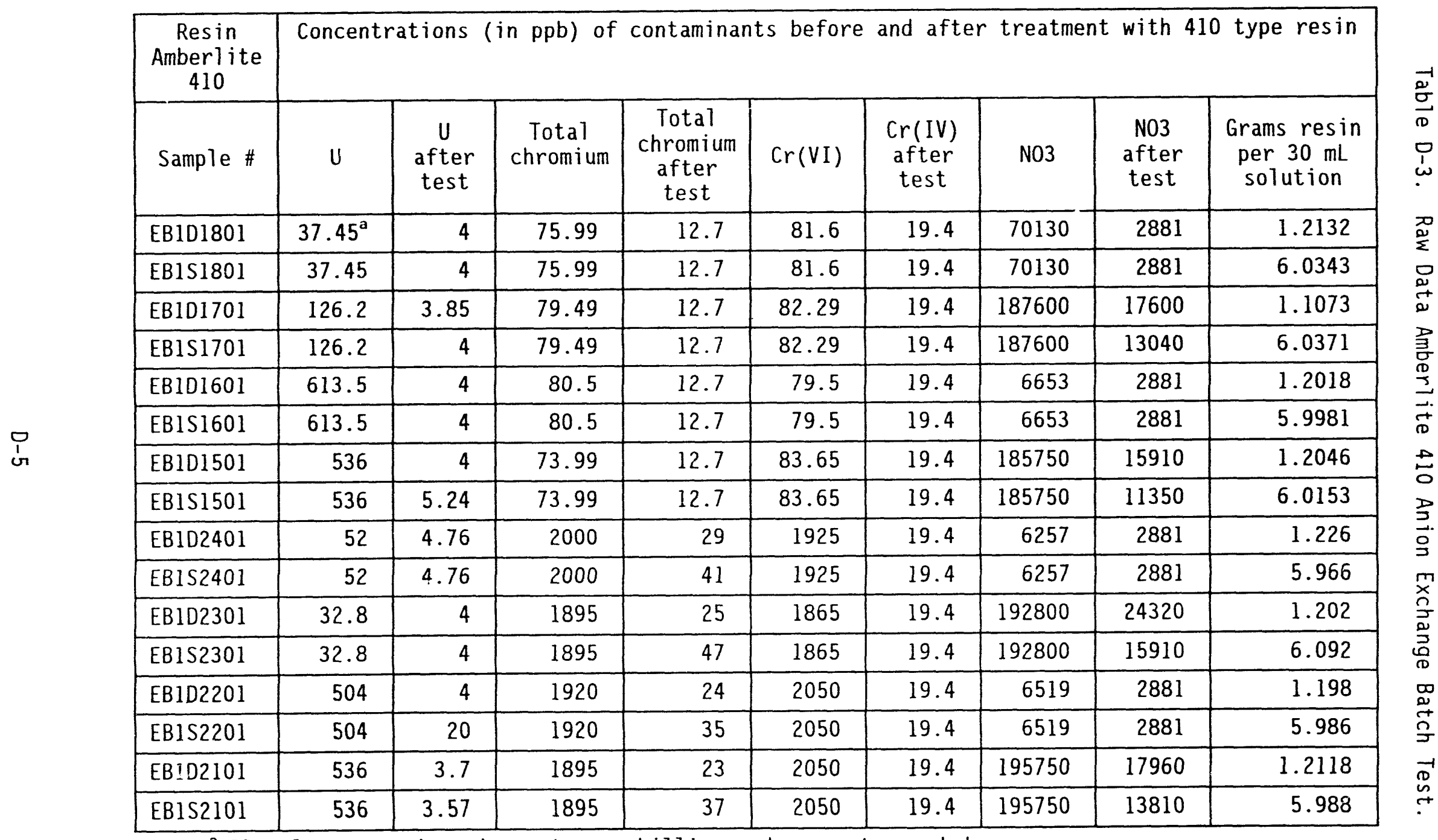

${ }^{\mathrm{a} A l l}$ values are given in parts per billion and are not rounded. 
WHC-SD-ER-DTR-001, Rev. 0 
WHC-SD-ER-DTR-001, Rev. 0

\section{APPENDIX E}

REGRESSION COEFFICIENT VALUES FOR ANION EXCHANGE METHODS 
WHC-SD-ER-DTR-001, Rev. 0

$E-2$ 


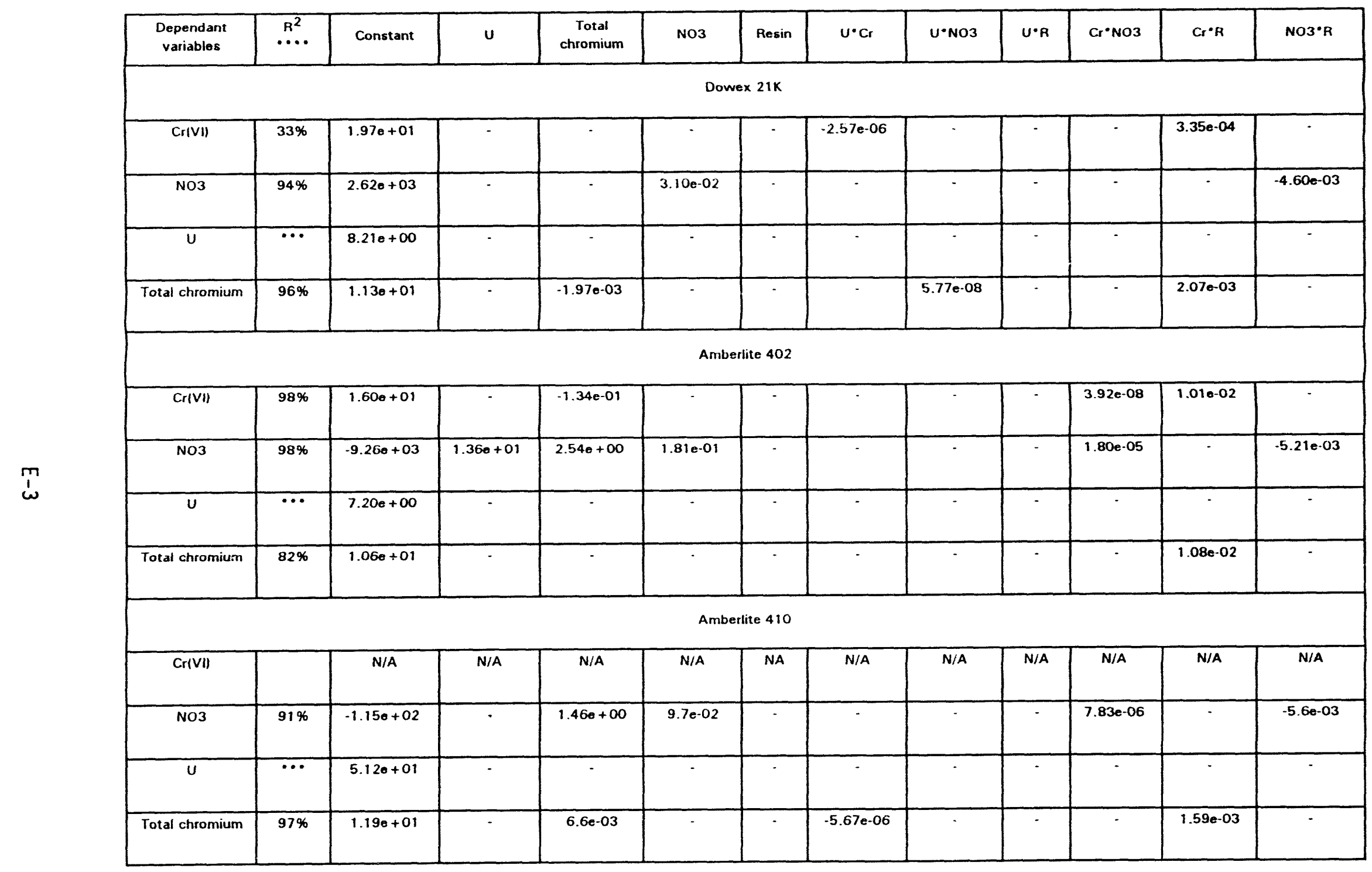

- A $(-)$ indicates that the term was not used in the final model to predict $C_{\text {finat }}$ i.e.. these regression coefficients are not significantly different from zero. -. N/A -- Not available, as the dependent variable was a constant (the analytical less than value).

$\cdots R^{2}$ is not applicable, as no regression equation (model) is used.

.... A dofinition of $R^{2}$ is the percent of total variability of the data explained by the regression equation. 
WHC-SD-ER-DTR-001, Rev. 0

$E-4$ 
WHC-SD-ER-DTR-001, Rev. 0

APPENDIX $F$

EQUILIBRIUM EXPERIMENT DATA 
WHC-SD-ER-DTR-001, Rev. 0

F-2 
WHC-SD-ER-DTR-001, Rev. 0

Table F-1. Equilibrium Experiment Raw Data.

\begin{tabular}{|l|r|r|r|r|r|}
\hline Sample \# & \multicolumn{1}{|c|}{$U$} & \multicolumn{1}{|c|}{ N03 } & $\begin{array}{r}\text { Total } \\
\text { chromium }\end{array}$ & Cr(VI) & $\begin{array}{c}\text { Mass of resin } \\
(\mathrm{g})\end{array}$ \\
\hline EBKT2111 & 534 & 196500 & 1870 & 1520 & $<--$ Standards \\
\hline EBKT2110 & 432 & 189000 & 1840 & 1540 & $<--$ Standards \\
\hline EBKS2111 & 4.5 & 119000 & 62 & 19.4 & 0.05 \\
\hline EBKS2110 & 21.1 & 69790 & 30 & 19.4 & 0.1071 \\
\hline EBKD2111 & 3.89 & 115000 & 29.8 & 19.4 & 0.0557 \\
\hline EBKD2110 & 5 & 71600 & 32 & 19.4 & 0.0986 \\
\hline EBKB0911 & 12.3 & 5955 & 29.8 & 19.4 & $<--$ Blanks \\
\hline EBKB0910 & 5.79 & 5030 & 29.8 & 19.4 & $<--$ Blanks \\
\hline Measured density of resin $0.86 \mathrm{~g} / \mathrm{mL}$ & & \\
\hline
\end{tabular}


WHC-SD-ER-DTR-001, Rev. 0

Table F-2. Liters of Solution 31 (Spiked 199-H3-2C) Treatable per Milliliter of Resin.

\begin{tabular}{|l|r|r|r|r|}
\hline \multicolumn{1}{|c|}{ Sample \# } & $U$ & Nitrate & $\begin{array}{c}\text { Total } \\
\text { chromium }\end{array}$ & $\operatorname{Cr}(\mathrm{VI})$ \\
\hline EBKS2111 & 54.9 & 0.3 & 14.9 & 40.2 \\
\hline EBKS2110 & 5.3 & 0.4 & 14.7 & 18.8 \\
\hline EBKD2111 & 57.0 & 0.3 & 28.4 & 36.1 \\
\hline EBKD2ij0 & 25.0 & 0.4 & 14.9 & 20.4 \\
\hline Average & 35.6 & 0.4 & 18.2 & 28.8 \\
\hline
\end{tabular}


WHC-SD-ER-DTR-001, Rev. 0

APPENDIX G

RESULTS OF THE LOW FLOW RATE SPIKED GROUNDWATER (WELL 199-H3-2C) BREAKTHROUGH TEST 
WHC-SD-ER-DTR-001, Rev. 0

G-2 


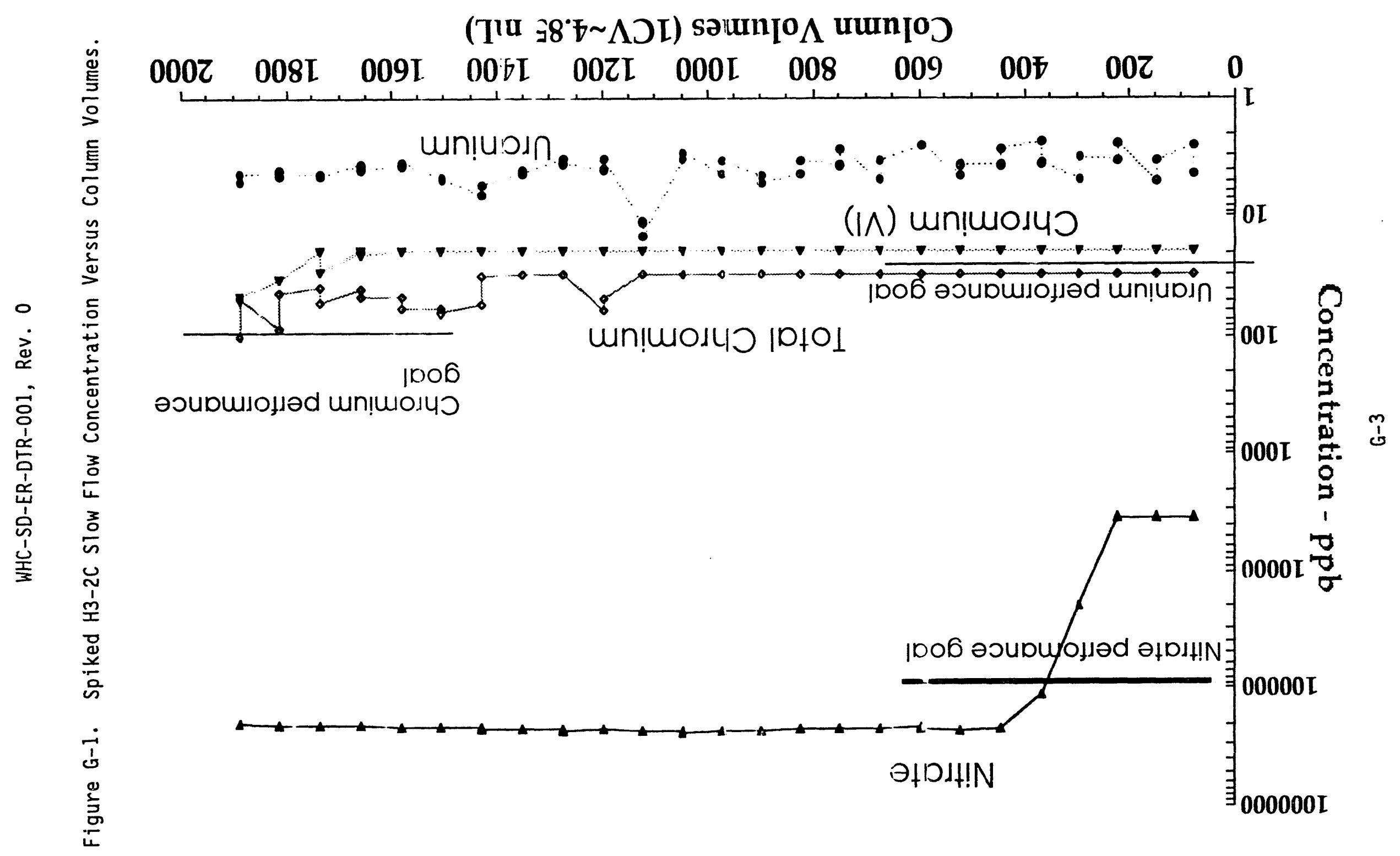




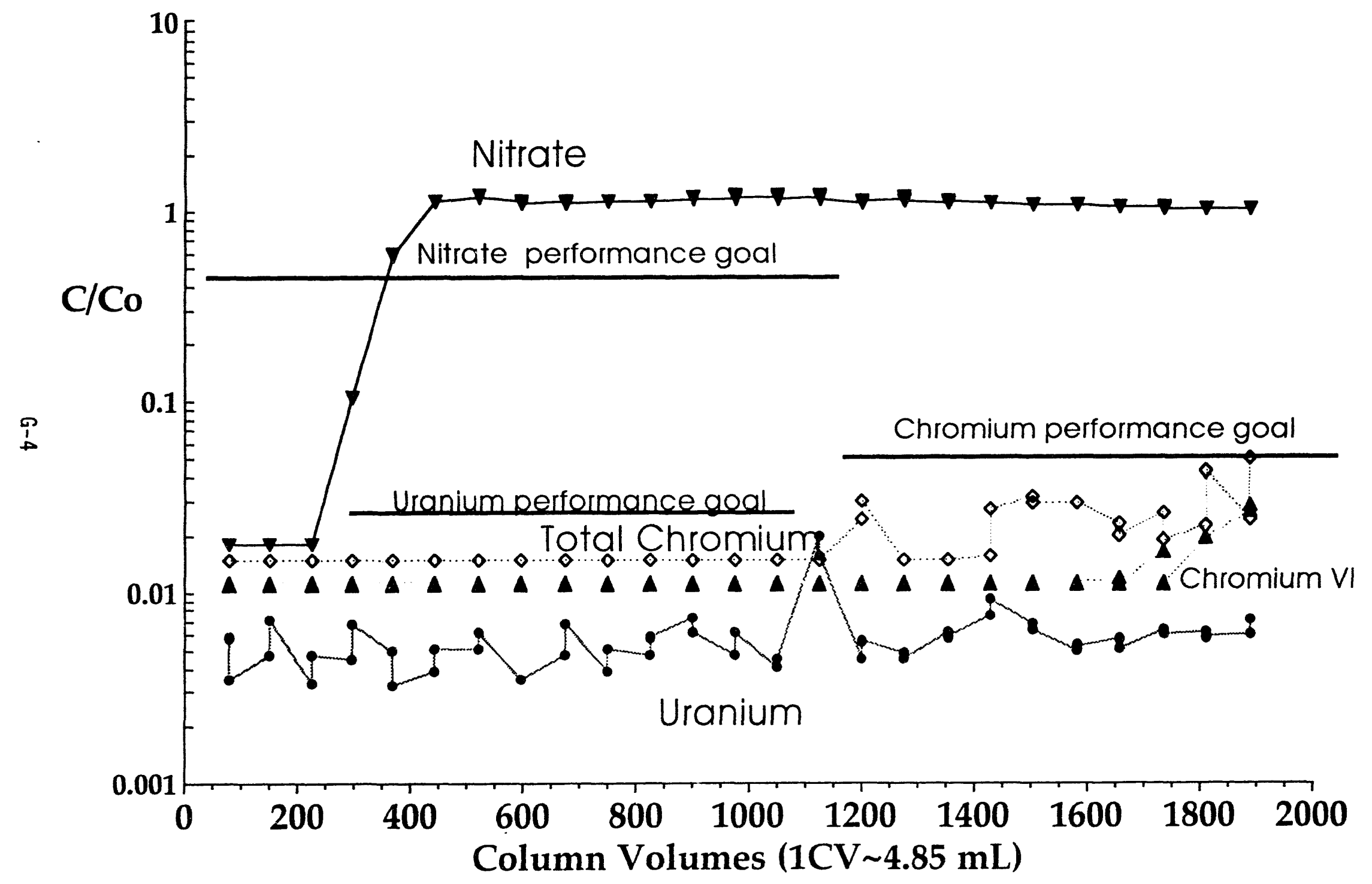

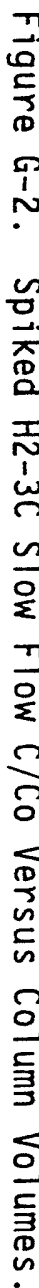




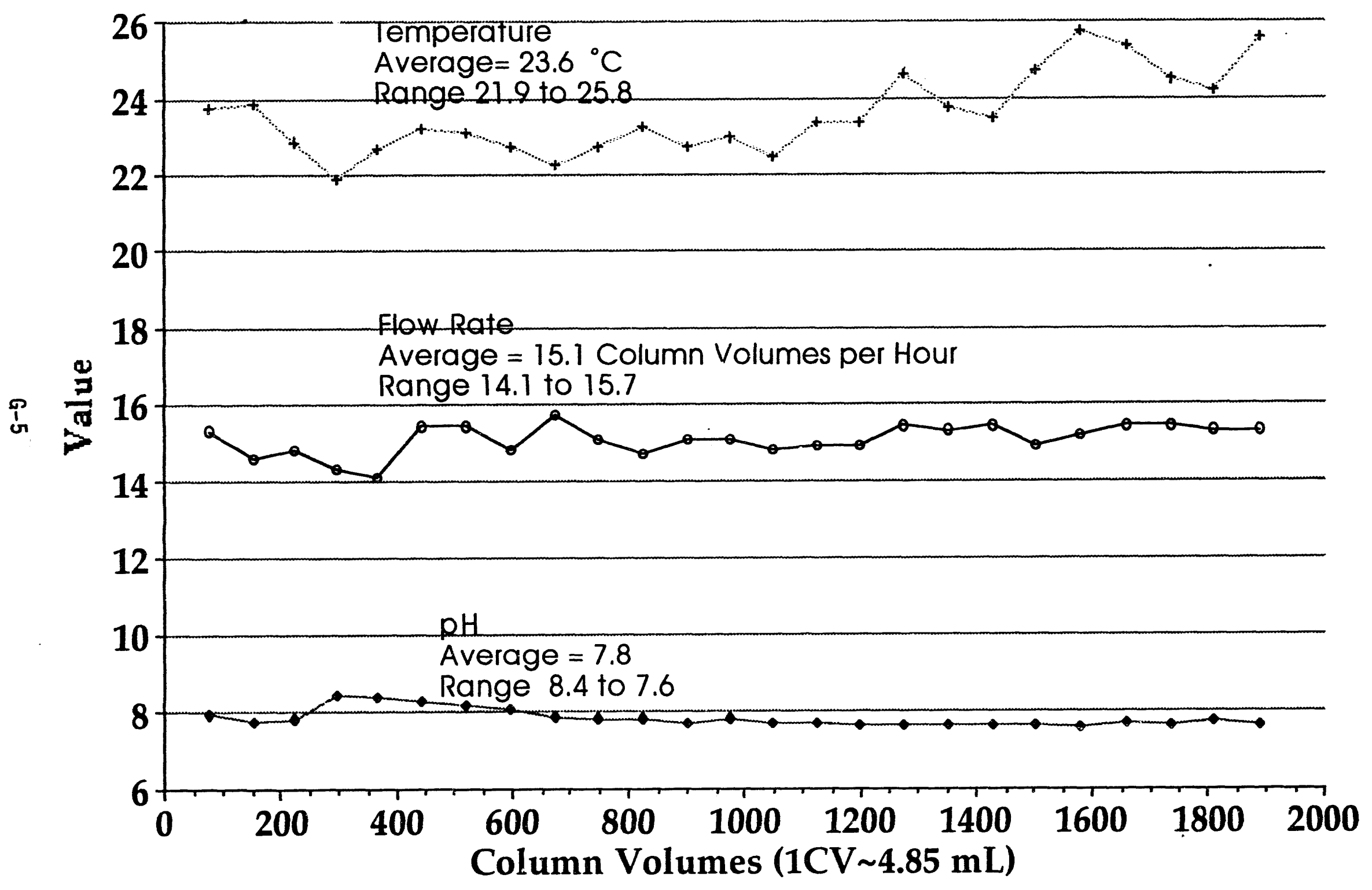


WHC-SD-ER-DTR-001, Rev. 0 


\begin{tabular}{|c|c|c|c|c|c|c|c|c|c|}
\hline $\begin{array}{l}\text { Laboratory } \\
\text { sample y }\end{array}$ & $\begin{array}{c}\text { Project } \\
\text { sample }\end{array}$ & $\begin{array}{l}\text { Cumulative Column } \\
\text { Volumes } \\
\text { (1 Column volume } \\
-4.85 \mathrm{~mL} \text { ) }\end{array}$ & $\begin{array}{l}\text { Uranium } \\
\text { Concentration } \\
\text { (ppb) }\end{array}$ & $\begin{array}{c}\text { Total } \\
\text { Chromium } \\
\text { Concentration } \\
\text { (ppb) }\end{array}$ & $\begin{array}{l}\text { Chromium (VI) } \\
\text { Concentration } \\
\text { (ppb) }\end{array}$ & $\begin{array}{c}\text { Nitrato } \\
\text { Concentration } \\
\text { (ppb) }\end{array}$ & $\begin{array}{l}\text { Flow Rate } \\
\text { (Column } \\
\text { Volumes per } \\
\text { Hour) }\end{array}$ & $\begin{array}{l}\text { Temperature } \\
\text { ( }{ }^{\circ} \mathrm{Cl} \text { at ond } \\
\text { of sample } \\
\text { collection }\end{array}$ & pH \\
\hline P 1554. & ERK31B01 & & 720 & 1990 & 1740 & 199100 & & & 8.47 \\
\hline P 1554. & ERK31B01 & & 705 & 2020 & 1820 & 187600 & & & \\
\hline P 1555. & ERK21TO1 & & 620 & 1930 & 1670 & 190500 & & & 8.3 \\
\hline P 1555. & ERK21TO1 & & 570 & 1920 & 1620 & 198600 & & & \\
\hline P 1556. & ERK31SO1 & 76.90722 & 4.2 & 29.8 & 19.4 & 3473 & 1.24 & 23.8 & 7.95 \\
\hline P 1556. & ERK31SO1 & 76.90722 & 2.5 & 29.8 & 19.4 & 3473 & 1.24 & & \\
\hline P 1557. & ERK31SO2 & 150.1031 & 3.3 & 29.8 & 19.4 & 3473 & 1.18 & 23.9 & 7.78 \\
\hline P 1557. & ERK31SO2 & 150.1031 & 5 & 29.8 & 19.4 & 3473 & 1.18 & & \\
\hline P 1558. & ERK31S03 & 224.3299 & 2.4 & 29.8 & 19.4 & 3473 & 1.2 & 22.9 & 7.82 \\
\hline P 1558. & ERK31SO3 & 224.3299 & 3.3 & 29.8 & 19.4 & 3473 & 1.2 & & \\
\hline P 1559. & ERK31S04 & 296825 & 3.2 & 29.8 & 19.4 & 19960 & 1.16 & 21.9 & 8.47 \\
\hline P 1559. & ERK31S04 & 296825 & 4.8 & 29.8 & 19.4 & 19930 & 1.16 & & \\
\hline P 1560. & ERK31SO5 & 366.5979 & 3.5 & 29.8 & 19.4 & 112900 & 1.14 & 22.7 & 8.38 \\
\hline P 1560. & ERK31S05 & 366.5979 & 2.3 & 29.8 & 19.4 & 112200 & 1.14 & & \\
\hline P 1561. & ERK31SO6 & 443.7113 & 2.7 & 29.8 & 19.4 & 222200 & 1.25 & 23.2 & 8.3 \\
\hline P 1561. & ERK31SO6 & 443.7113 & 3.6 & 29.8 & 19.4 & 220800 & 1.25 & & \\
\hline P 1562. & ERK31S07 & 521309 & 3.6 & 29.8 & 19.4 & 228400 & 1.25 & 23.1 & 8.19 \\
\hline P 1562. & ERK31507 & 521309 & 4.4 & 29.8 & 19.4 & 228700 & 1.25 & & \\
\hline P 1563. & ERK31SO8 & 595.2577 & 2.5 & 29.8 & 19.4 & 218200 & 1.2 & 22.8 & 84 \\
\hline P : 563. & ERK31S08 & 595.2577 & 2.5 & 29.8 & 19.4 & 212900 & 1.2 & & \\
\hline P 1564. & ERK31SO9 & 673.8144 & 3.3 & 29.8 & 19.4 & 217200 & 1.27 & 22.3 & 7.88 \\
\hline P 1564. & ERK31SO9 & 673.8144 & 4.8 & 29.8 & 19.4 & 215900 & 1.27 & & \\
\hline P 1565. & ERK31S10 & 749.4845 & 2.7 & 29.8 & 19.4 & 219500 & 1.22 & 22.8 & 7.83 \\
\hline P 1565. & ERK31S10 & 749.4845 & 3.6 & 29.8 & 19.4 & 217500 & 1.22 & & \\
\hline P 1566. & ERK31S11 & 823.5052 & 3.3 & 29.8 & 19.4 & 221200 & 1.19 & 23.3 & 7.86 \\
\hline P 1566. & ERK31S11 & 823.5052 & 4.2 & 29.8 & 19.4 & 218600 & 1.19 & & \\
\hline
\end{tabular}




\begin{tabular}{|c|c|c|c|c|c|c|c|c|c|}
\hline $\begin{array}{l}\text { Laboratory } \\
\text { sample * }\end{array}$ & $\begin{array}{l}\text { Project } \\
\text { sample }\end{array}$ & $\begin{array}{l}\text { Cumulative Column } \\
\text { Volumes } \\
\text { (1 Column volume } \\
-4.85 \mathrm{~mL})\end{array}$ & $\begin{array}{c}\text { Uranium } \\
\text { Concentration } \\
\text { (ppb) }\end{array}$ & $\begin{array}{c}\text { Total } \\
\text { Chromium } \\
\text { Concentration } \\
\text { (ppb) }\end{array}$ & $\begin{array}{c}\text { Chromium (VI) } \\
\text { Concentration } \\
\text { (ppb) }\end{array}$ & $\begin{array}{c}\text { Nitrate } \\
\text { Concentration } \\
\text { (ppb) }\end{array}$ & $\begin{array}{l}\text { Flow Rate } \\
\text { (Column } \\
\text { Volumes per } \\
\text { Hour) }\end{array}$ & $\begin{array}{l}\text { Temperature } \\
\left({ }^{\circ} \mathrm{Cl} \text { at ond }\right. \\
\text { of sample } \\
\text { colloction }\end{array}$ & pH \\
\hline P 1567. & ERK31S12 & 898.9691 & 5.2 & 29.8 & 19.4 & 226100 & 1.22 & 22.8 & 7.75 \\
\hline P 1567. & ERK31S12 & 898.9691 & 4.4 & 29.8 & 19.4 & 227900 & 1.22 & & \\
\hline P 1568. & ERK31S13 & 974.433 & 3.3 & 29.8 & 19.4 & 226500 & 1.22 & 23 & 7.82 \\
\hline P 1568. & ERK31S13 & 974.433 & 4.3 & 29.8 & 19.4 & 228900 & 1.22 & & \\
\hline P 1569. & ERK31S14 & 1048.577 & 2.9 & 29.8 & 19.4 & 231500 & 1.2 & 22.5 & 7.73 \\
\hline P 1569. & ERK31S14 & 1048.577 & 3.2 & 29.8 & 19.4 & 226600 & 1.2 & & \\
\hline P 1570. & ERK31S15 & 1123.423 & 14.1 & 29.8 & 19.4 & 228800 & 1.21 & 23.4 & 7.72 \\
\hline P 1570. & ERK31S15 & 1123.423 & 10.8 & $\therefore 9.8$ & 19.4 & 227500 & 1.21 & & \\
\hline P 1571. & ERK31S16 & 1198.268 & 3.2 & 48 & 19.4 & 216000 & 1.21 & 23.4 & 7.68 \\
\hline P 1571. & ERK31S16 & 1198.268 & 3.9 & 60 & 19.4 & 219700 & 1.21 & & \\
\hline P 1572. & ERK31S17 & 1275.381 & 3.5 & 29.8 & 19.4 & 227300 & 1.25 & 24.6 & 7.69 \\
\hline P 1572. & ERK31S17 & 1275.381 & 3.2 & 29.8 & 19.4 & 221700 & 1.25 & & \\
\hline P 1573. & ERK31S18 & 1351.876 & 4.3 & 29.8 & 19.4 & 215400 & 1.24 & 23.8 & 7.66 \\
\hline P 1573. & ERK31S18 & 1351.876 & 49 & 29.8 & 19.4 & 217200 & 1.24 & & \\
\hline P 1574. & ERK31S19 & 1429.196 & 5.3 & 31 & 19.4 & 215600 & 1.25 & 23.5 & 7.68 \\
\hline P 1574. & ERK31S19 & 1429.196 & 6.5 & 54 & 19.4 & 213900 & 1.25 & & \\
\hline P 1575. & ERK31S20 & 1504.247 & 4.8 & 64 & 19.4 & 208900 & 1.21 & 24.7 & 7.69 \\
\hline P 1575. & ERK31S20 & 1504.247 & 4.5 & 59 & 19.4 & 209000 & 1.21 & & \\
\hline P 1576. & ERK31S21 & 1580.536 & 3.5 & 45 & 19.4 & 207600 & 1.23 & 25.8 & 7.63 \\
\hline P 1576. & ERK31S21 & 1580.536 & 3.7 & 42 & 19.4 & 206400 & 1.23 & & \\
\hline P 1577. & ERK31S22 & 1657.649 & 4 & 46 & 20.7 & 205000 & 1.25 & 25.4 & 7.73 \\
\hline P 1577. & ERK31S22 & 1657.649 & 3.6 & 40 & 19.4 & 201400 & 1.25 & & \\
\hline P 1578. & ERK31S23 & 1734.969 & 4.4 & 52 & 28.5 & 202500 & 1.25 & 24.5 & 7.69 \\
\hline P 1578. & ERK31S23 & 1734.969 & 4.2 & 38 & 19.4 & 200800 & 1.25 & & \\
\hline P 1579. & ERK31S24 & 1811.876 & 4.4 & 59 & 33.7 & 199200 & 1.24 & 24.2 & 7.79 \\
\hline P 1579. & ERK31S24 & 1811.876 & 49 & 60 & 33.7 & 199100 & 1.24 & & \\
\hline
\end{tabular}




\begin{tabular}{|c|c|c|c|c|c|c|c|c|c|}
\hline $\begin{array}{l}\text { Laboratory } \\
\text { samplo : }\end{array}$ & $\begin{array}{c}\text { Projoct } \\
\text { samplo }\end{array}$ & $\begin{array}{l}\text { Cumulative Column } \\
\text { Volumes } \\
\text { (1 Column volume } \\
-4.85 \mathrm{~mL}\end{array}$ & $\begin{array}{c}\text { Uranium } \\
\text { Concentration } \\
\text { (ppb) }\end{array}$ & $\begin{array}{l}\text { Total } \\
\text { Chromium } \\
\text { Concontration } \\
\text { (ppb) }\end{array}$ & $\begin{array}{l}\text { Chromium (VI) } \\
\text { Concentration } \\
\text { (ppb) }\end{array}$ & $\begin{array}{c}\text { Nitrate } \\
\text { Concontration } \\
\text { (ppb) }\end{array}$ & $\begin{array}{l}\text { Flow Rate } \\
\text { (Column } \\
\text { Volumes per } \\
\text { Hour) }\end{array}$ & $\begin{array}{l}\text { Temperature } \\
\text { ('०) at end } \\
\text { of sample } \\
\text { colloction }\end{array}$ & pH \\
\hline P 1580. & ERK31S25 & 1888.557 & 4.2 & 68 & 46.7 & 196300 & 1.24 & 25.6 & 7.65 \\
\hline P 1580. & ERK31S25 & 1888.557 & 5 & 64 & 50.6 & 197200 & 1.24 & & \\
\hline P 1581. & ERK31802 & & 765 & 2060 & 1750 & 192500 & & & 85 \\
\hline P 1581. & ERK31BO2 & & 645 & 2033 & 1760 & 189900 & & & \\
\hline
\end{tabular}


WHC-SD-ER-DTR-001, Rev. 0 
WHC-SD-ER-DTR-001, Rev. 0

\section{APPENDIX H}

RESULTS OF THE HIGH FLOW RATE SPIKED GROUNDWATER

(WELL H3-2C) BREAKTHROUGH TEST 
Hiti-SD-ER-DTR-001, Rev. 0

H-2 


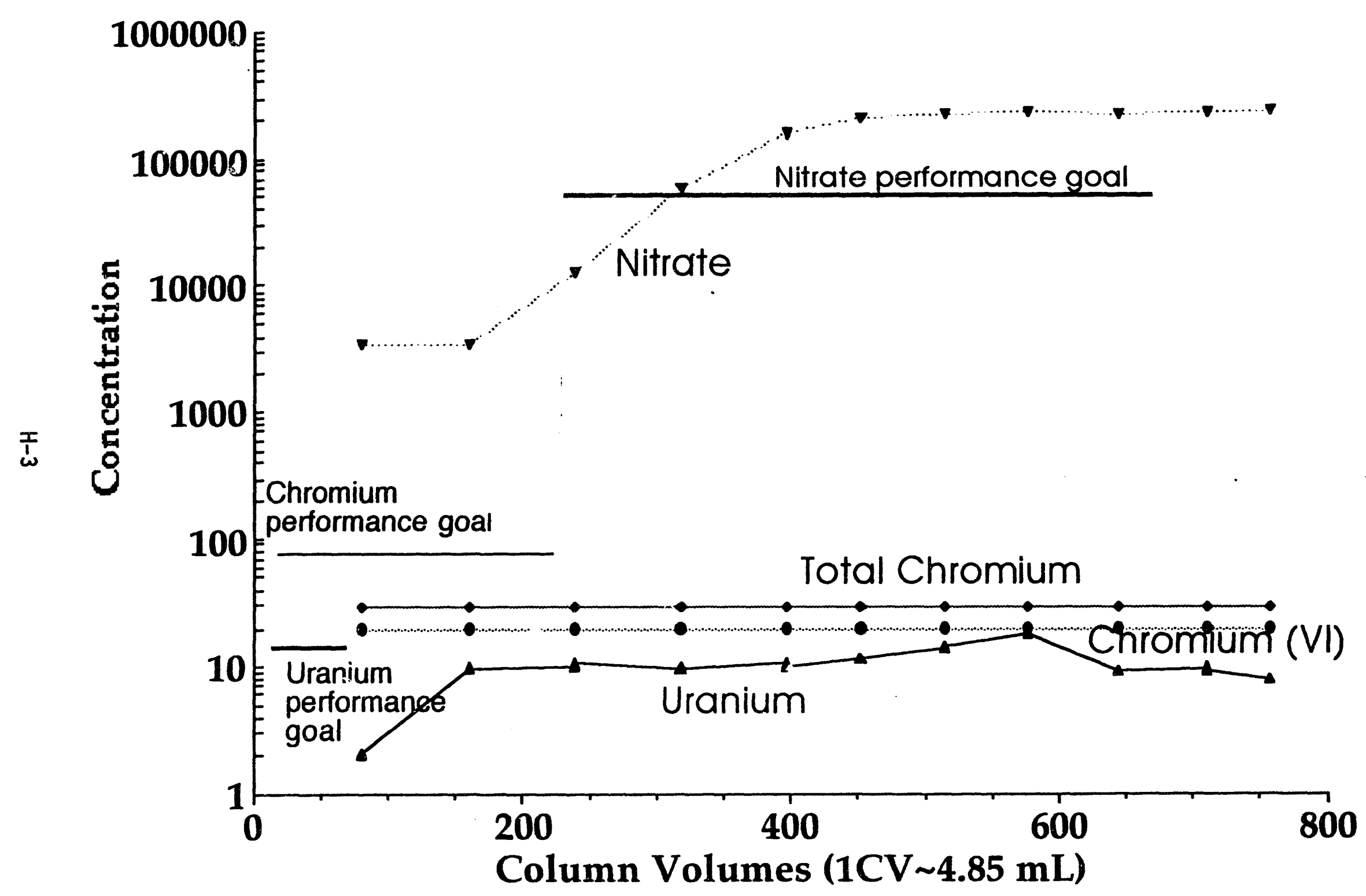




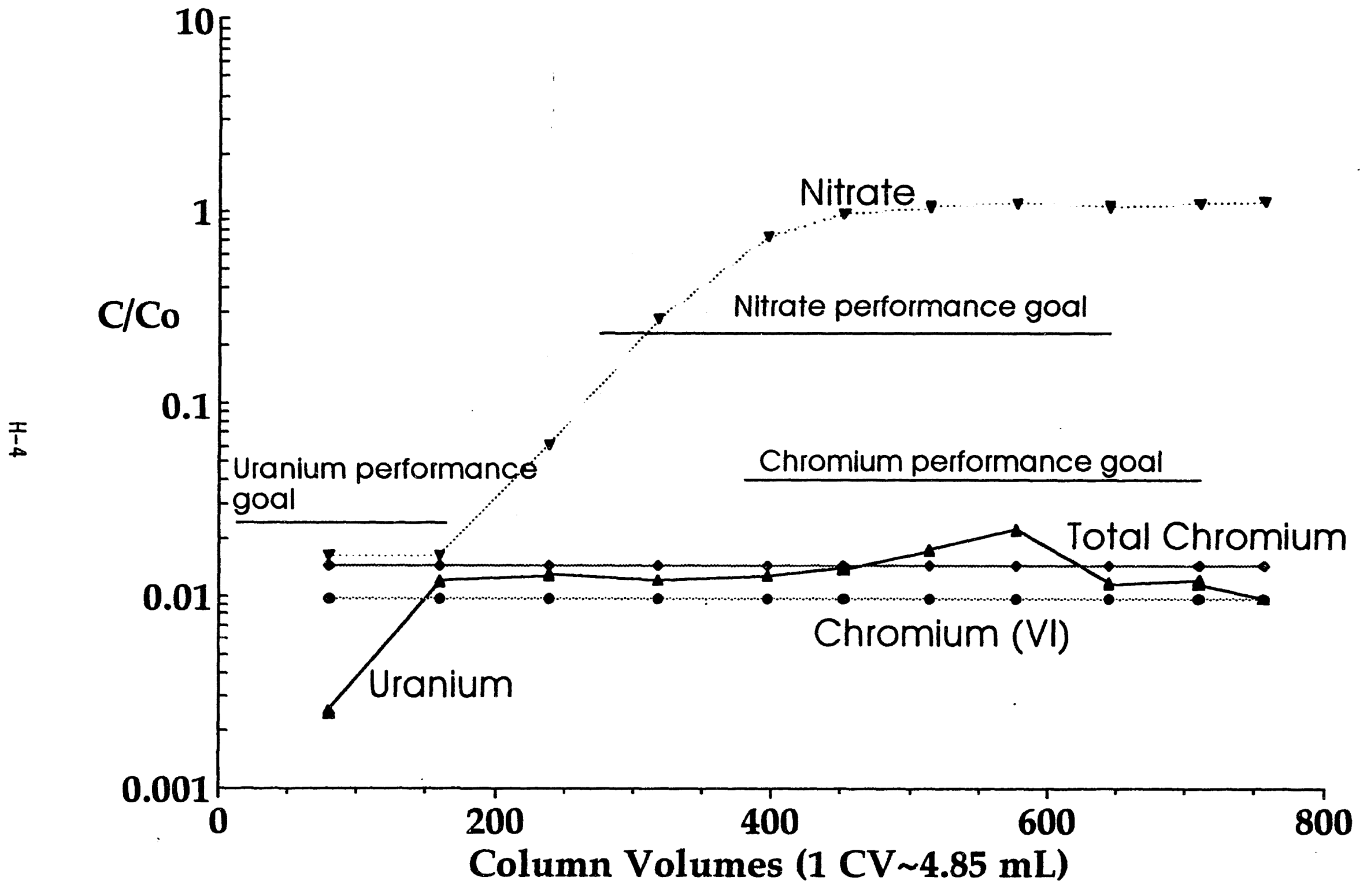

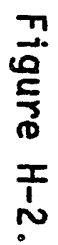

ڤัง

을

8

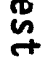

돔

离

志 


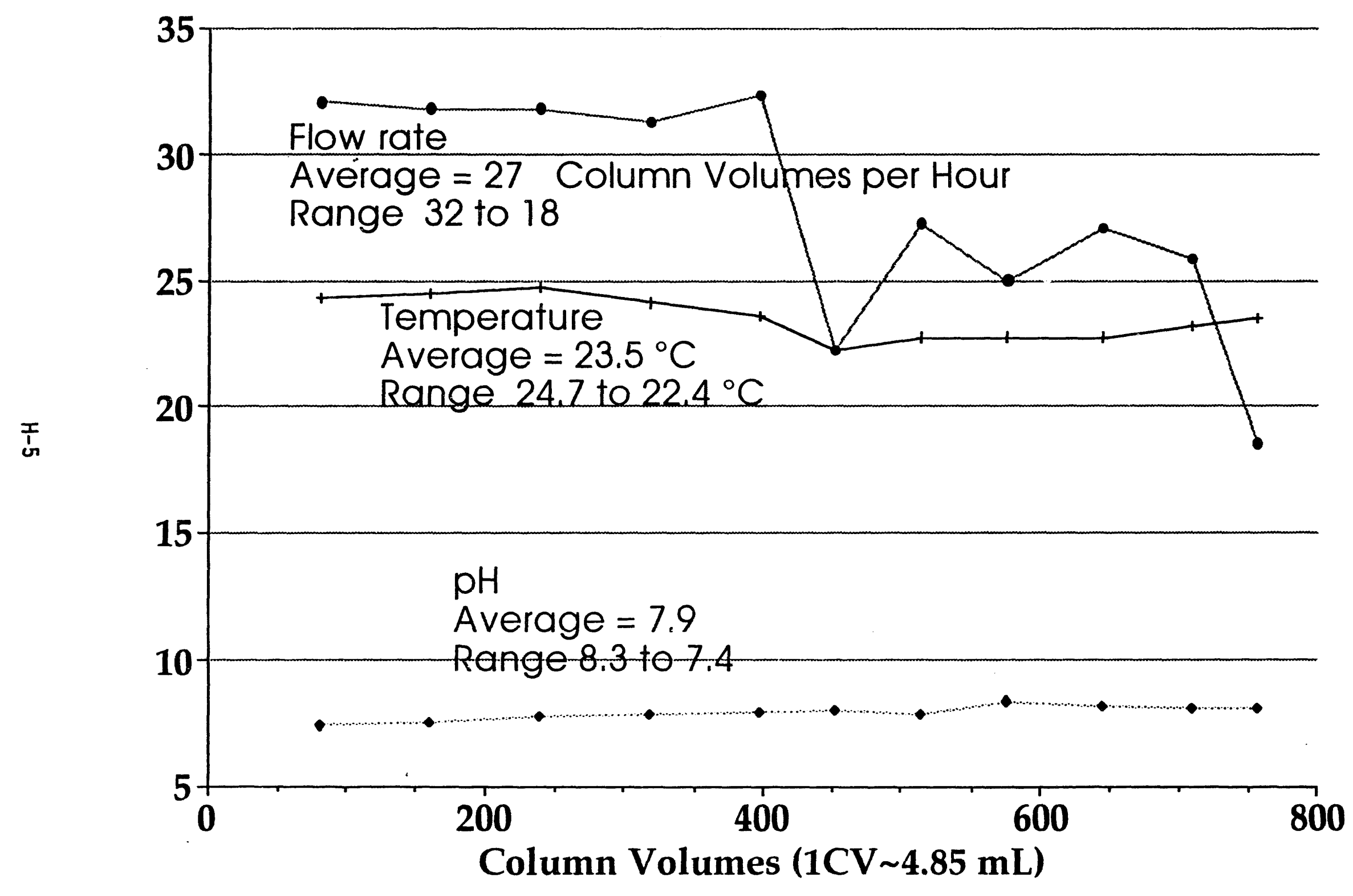


WHC-SD-ER-DTR-001, Rev. 0

H-6 


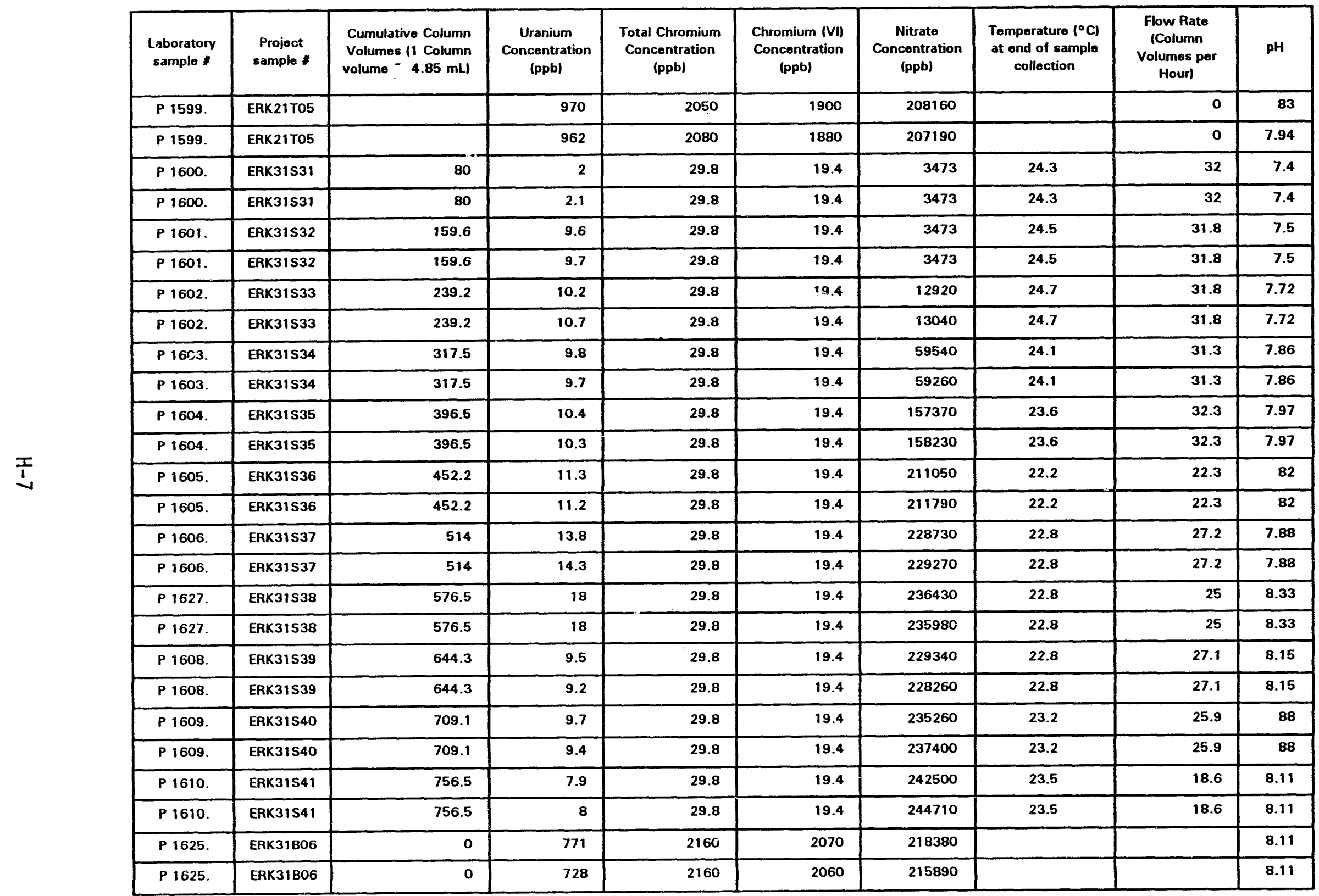


WHC-SD-ER-DTR-001, Rev. 0

H-8 
WHC-SD-ER-DTR-001, Rev. 0

APPENDIX I

RESULTS OF THE UNSPIKED GROUNDWATER (WELL 199-H4-4) BREAKTHROUGH TEST 
WHC-SD-ER-DTR-001, Rev. 0 

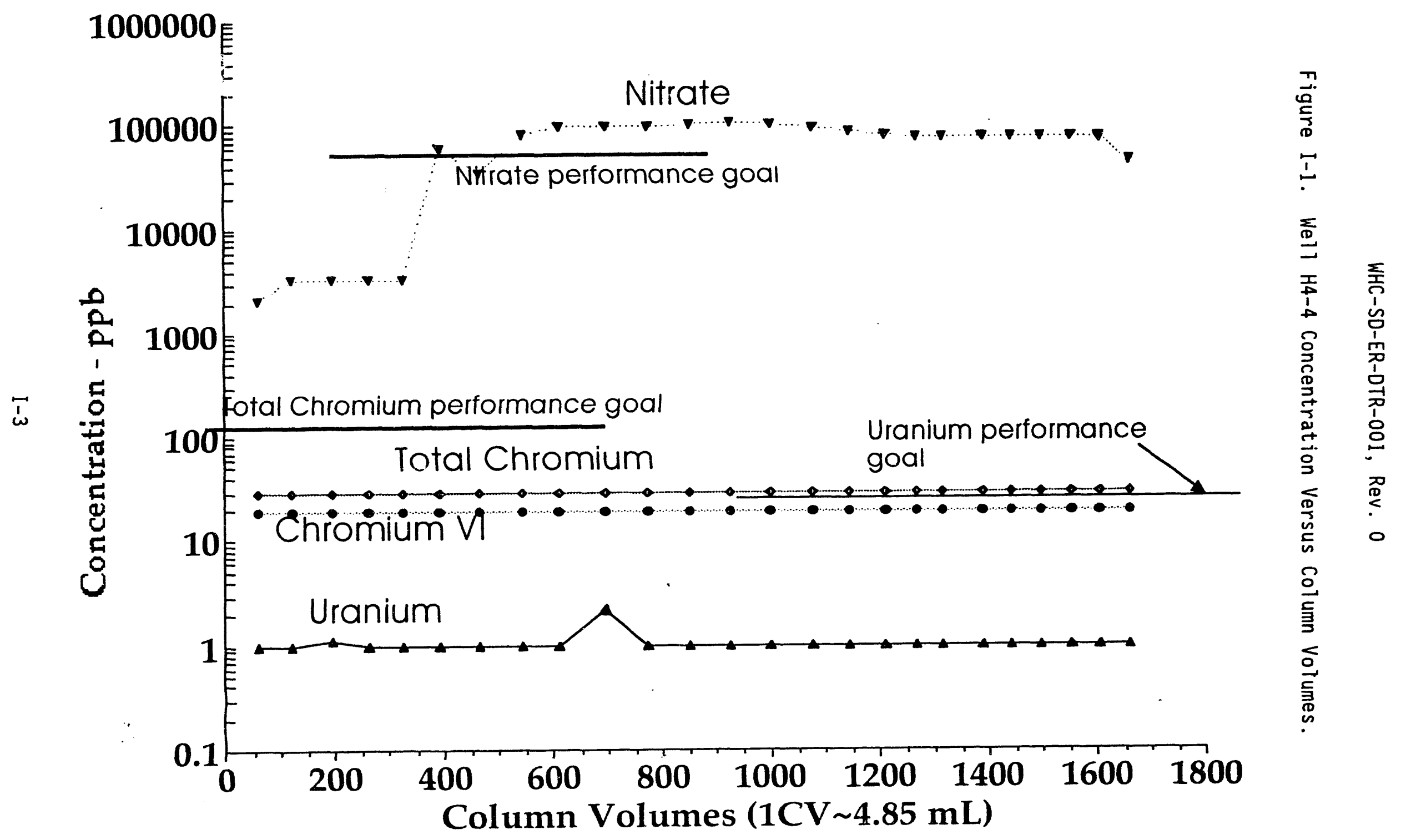


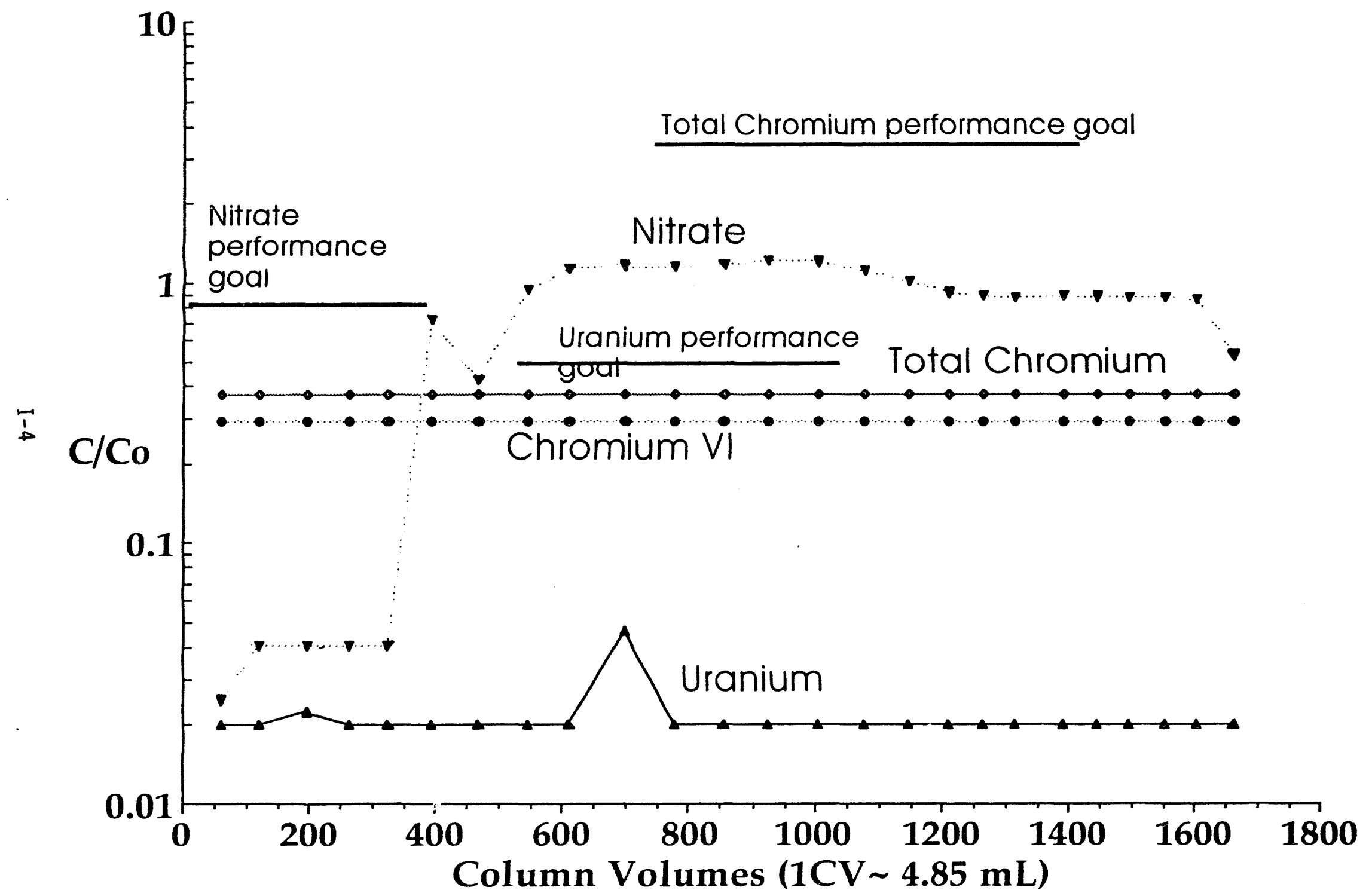




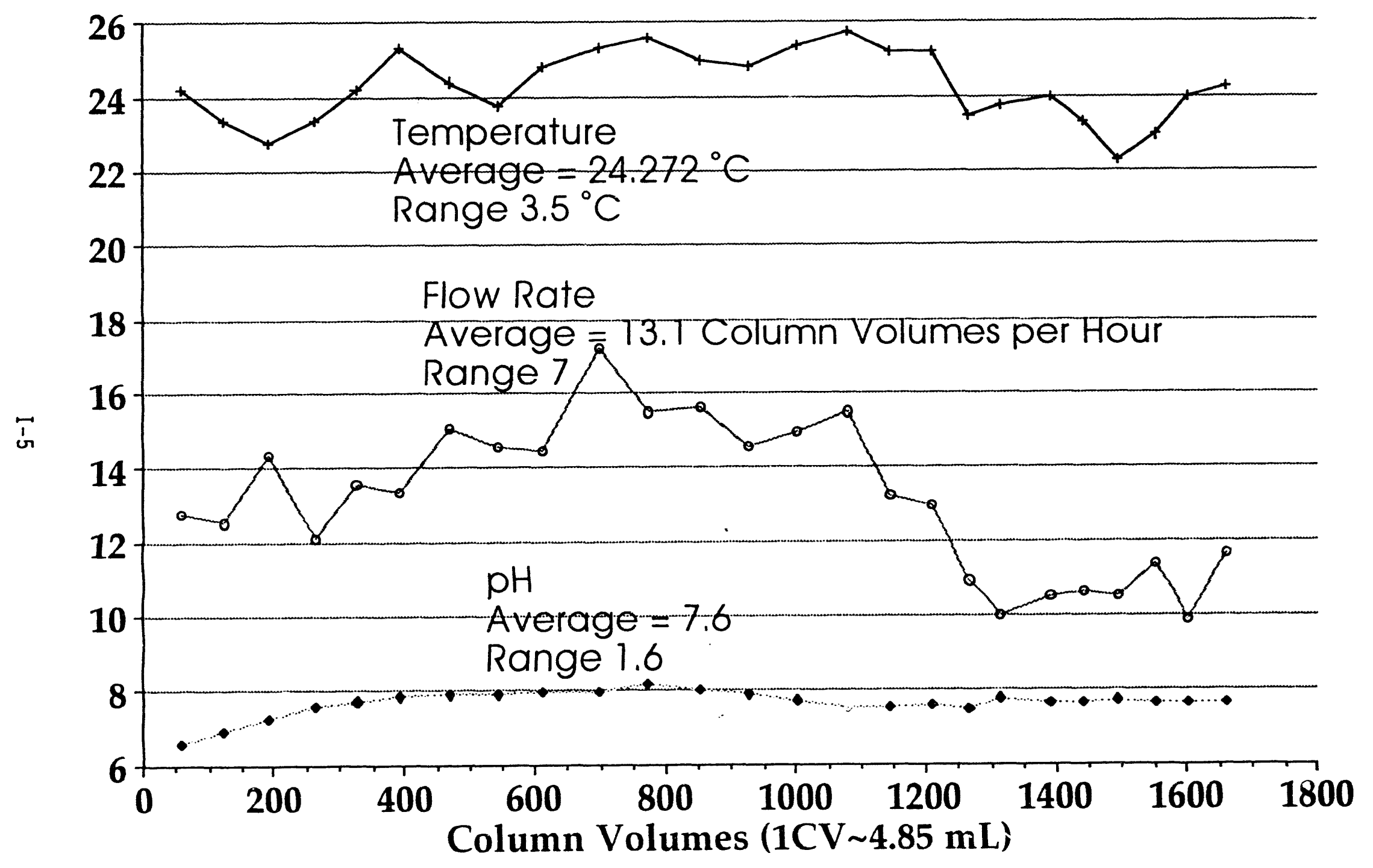

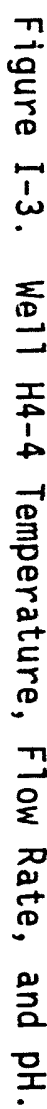


WHC-SD-ER-DTR-001, Rev. 0 


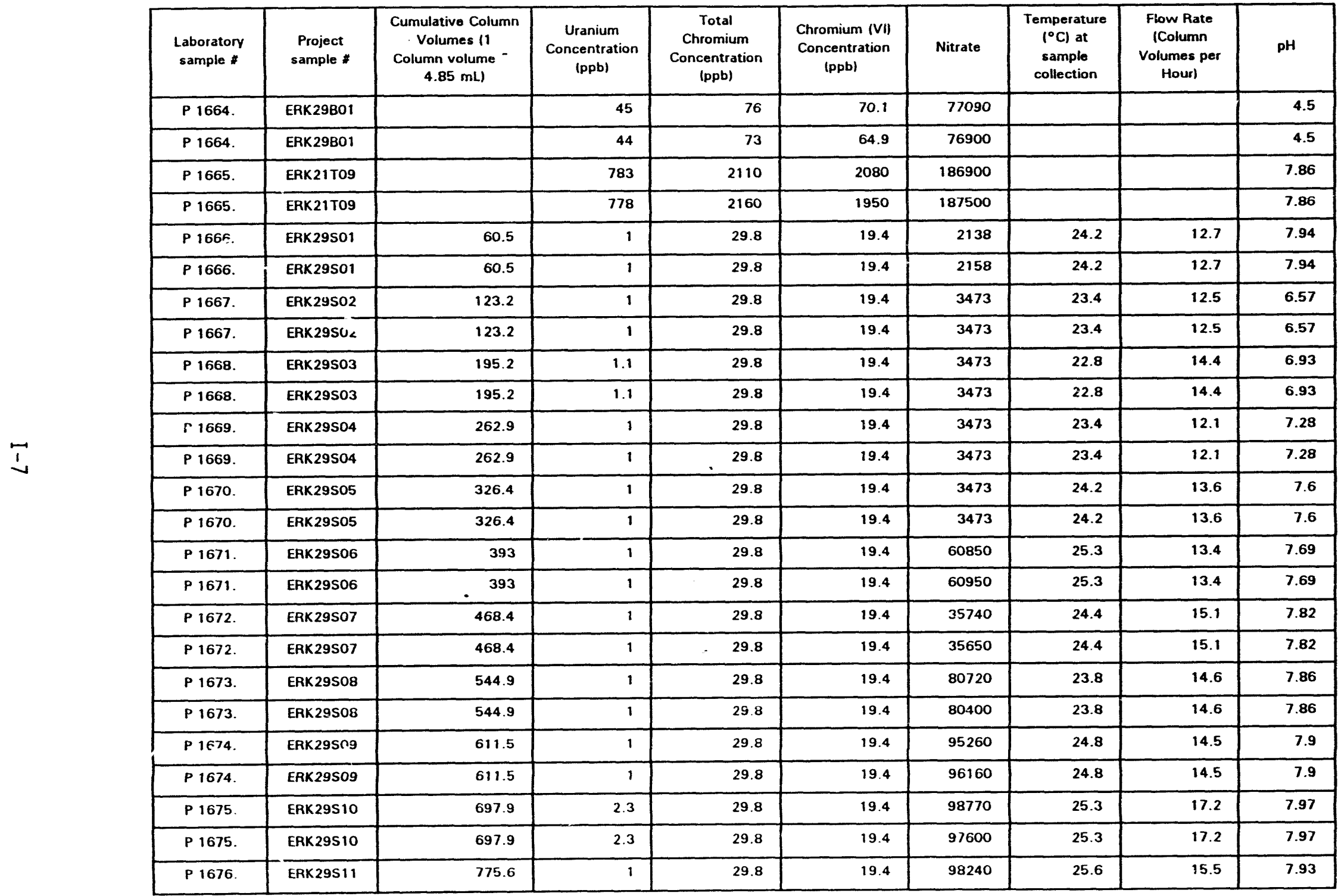




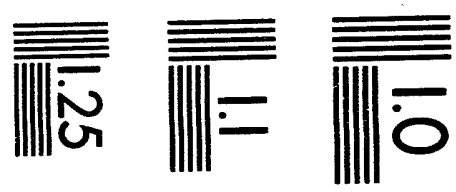

$$
\begin{aligned}
& \text { 春至 }
\end{aligned}
$$

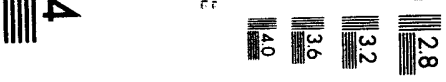

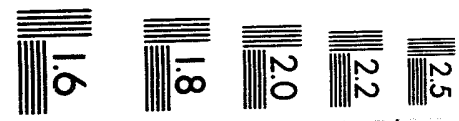



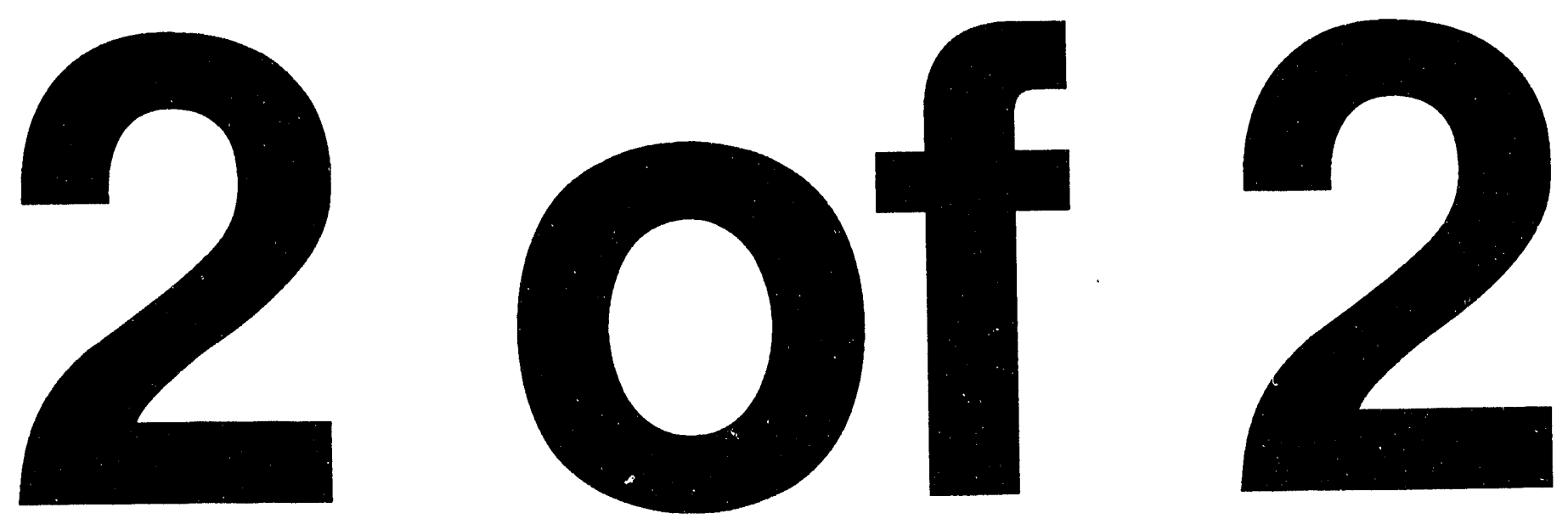


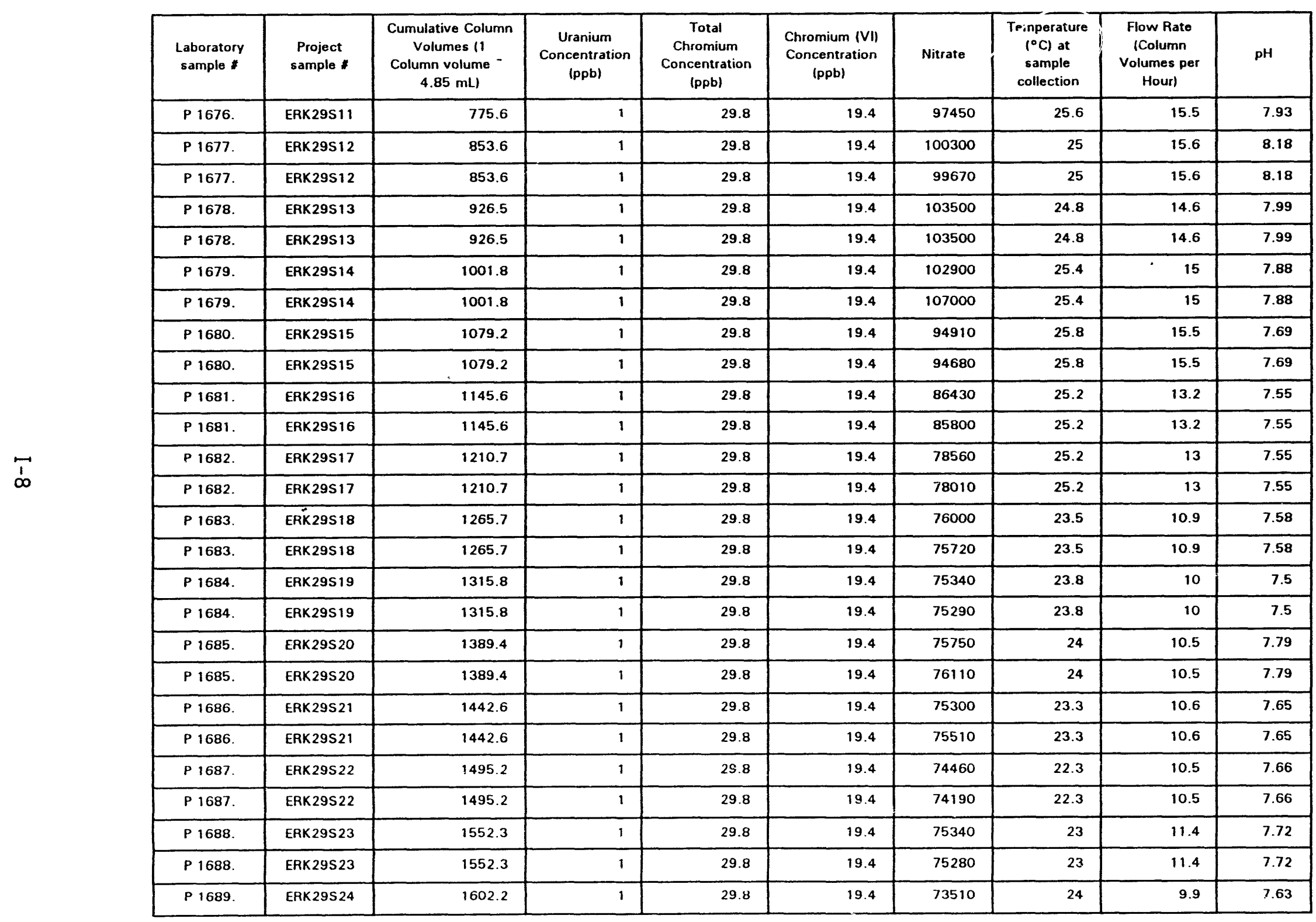




\begin{tabular}{|c|c|c|c|c|c|c|c|c|c|}
\hline $\begin{array}{l}\text { Laboratory } \\
\text { sample }\end{array}$ & $\begin{array}{c}\text { Project } \\
\text { sample * }\end{array}$ & $\begin{array}{l}\text { Cumulative Column } \\
\text { Volumes (1 } \\
\text { Column volume - } \\
4.85 \mathrm{~mL} \text { ) }\end{array}$ & $\begin{array}{c}\text { Uranium } \\
\text { Concentration } \\
(p p b)\end{array}$ & $\begin{array}{c}\text { Total } \\
\text { Chromium } \\
\text { Concentration } \\
\text { (ppb) }\end{array}$ & $\begin{array}{c}\text { Chromium (VI) } \\
\text { Concentration } \\
\text { (ppb) }\end{array}$ & Nitrate & $\begin{array}{l}\text { Temperature } \\
\left({ }^{\circ} \mathrm{C}\right) \text { at } \\
\text { sample } \\
\text { collection }\end{array}$ & $\begin{array}{l}\text { Flow Rate } \\
\text { (Column } \\
\text { Volumes per } \\
\text { Hour) }\end{array}$ & pH \\
\hline P 1689. & ERK 29S24 & 1602.2 & 1 & 29.8 & 19.4 & 73940 & 24 & 9.9 & 7.63 \\
\hline P 1690. & ERK29S25 & 1660.4 & 1 & 29.8 & 19.4 & 44570 & 24.3 & 11.6 & 7.63 \\
\hline P 1690. & ERX29S 25 & 1660.4 & 1 & 29.8 & 19.4 & $45 C 20$ & 24.3 & 11.6 & 7.63 \\
\hline P 1691. & ERK 29BO2 & & 54 & 88 & 66.2 & 92400 & & & 7.65 \\
\hline P 1691. & ERK29BO2 & & 53 & 81 & 61 & 92100 & & & 7.65 \\
\hline
\end{tabular}


WHC-SD-ER-DTR-001, Rev. 0 
WHC-SD-ER-DTR-001, Rev. 0

\section{APPENDIX J}

RESULTS OF THE UNSPIKED GROUNDWATER (WELL D5-15) BREAKTHROUGH TEST 
WHC-SD-ER-DTR-001, Rev. 0

$$
\mathrm{J}-2
$$



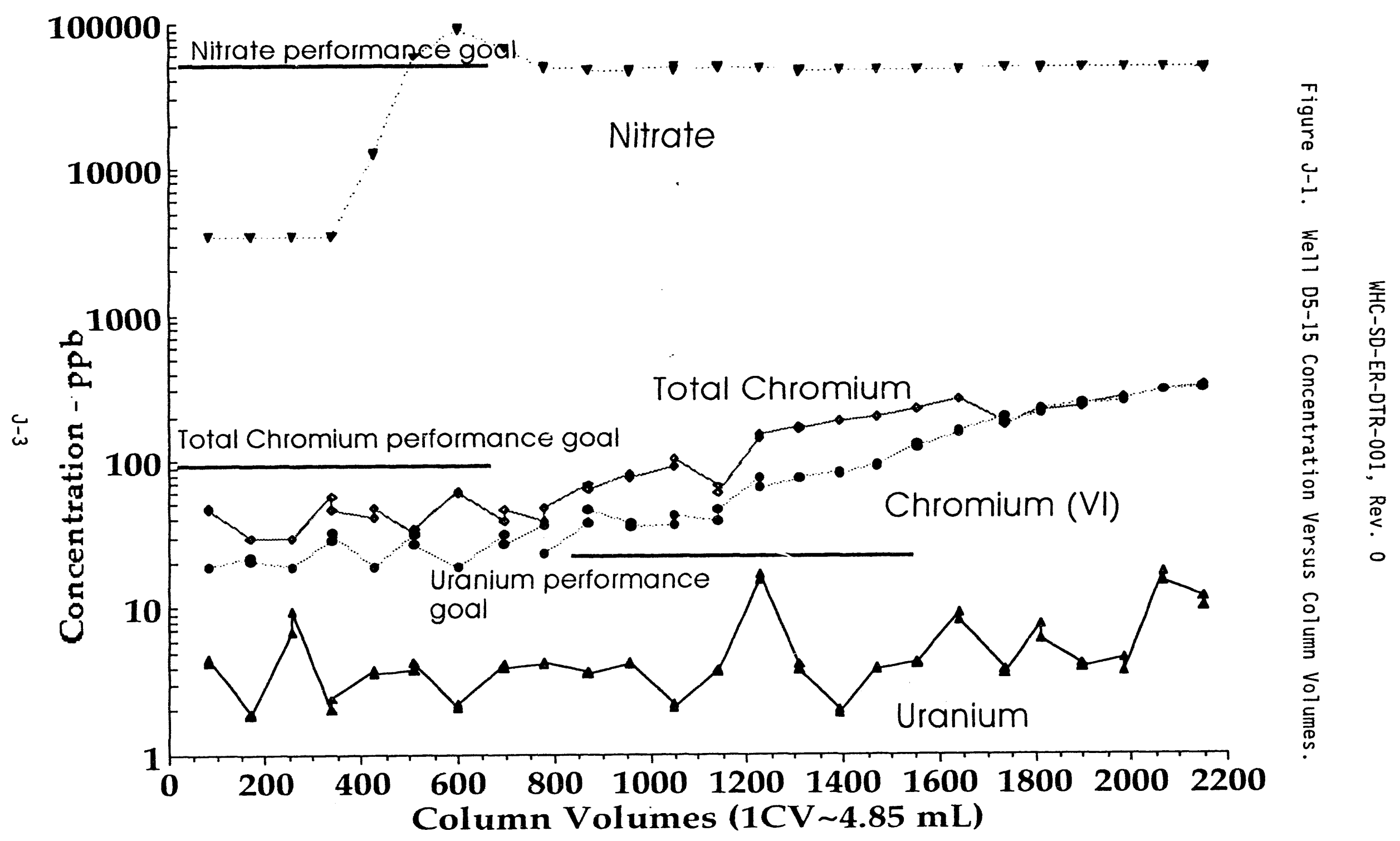


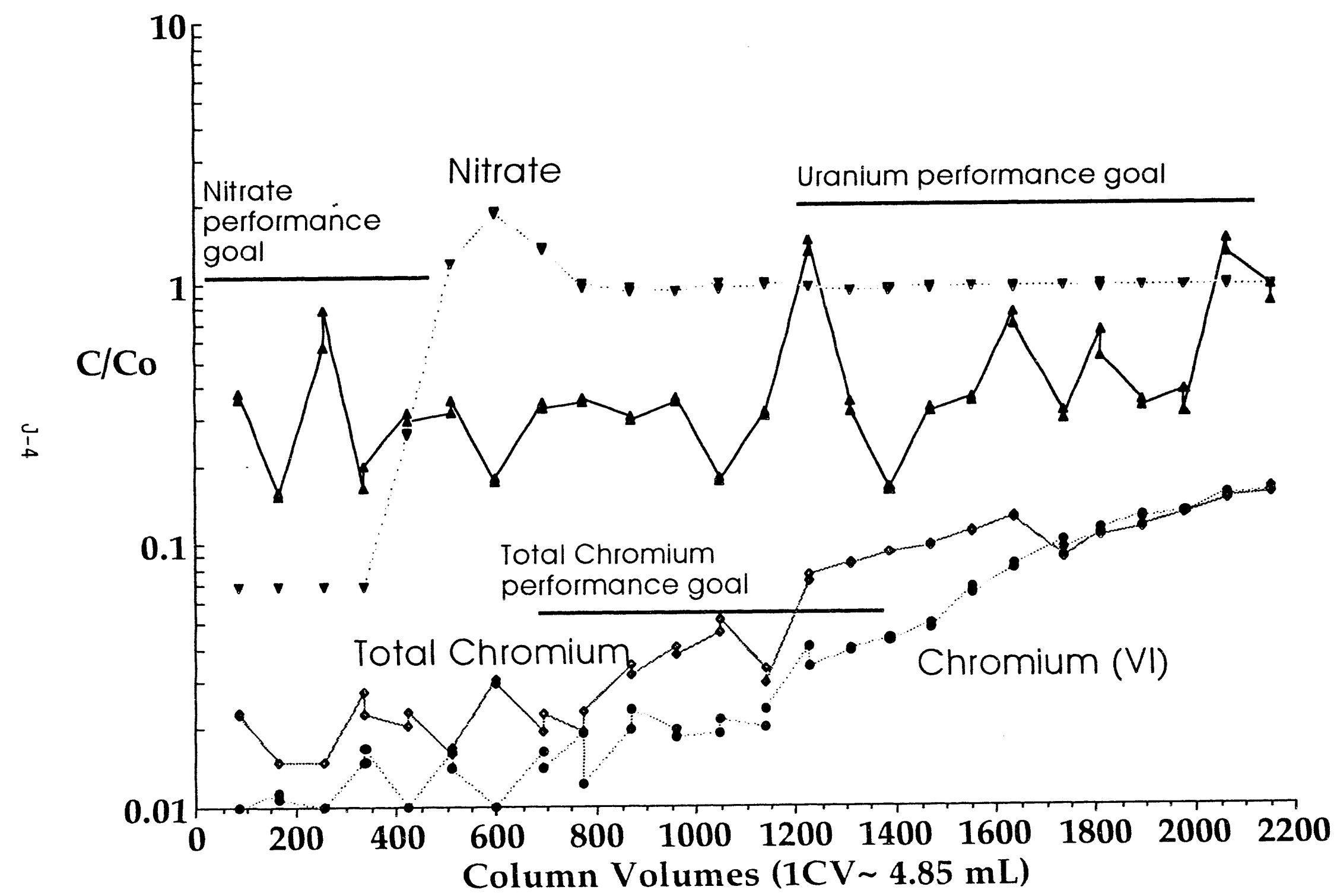

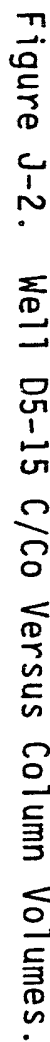

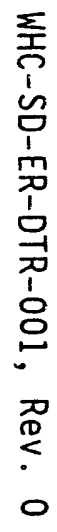




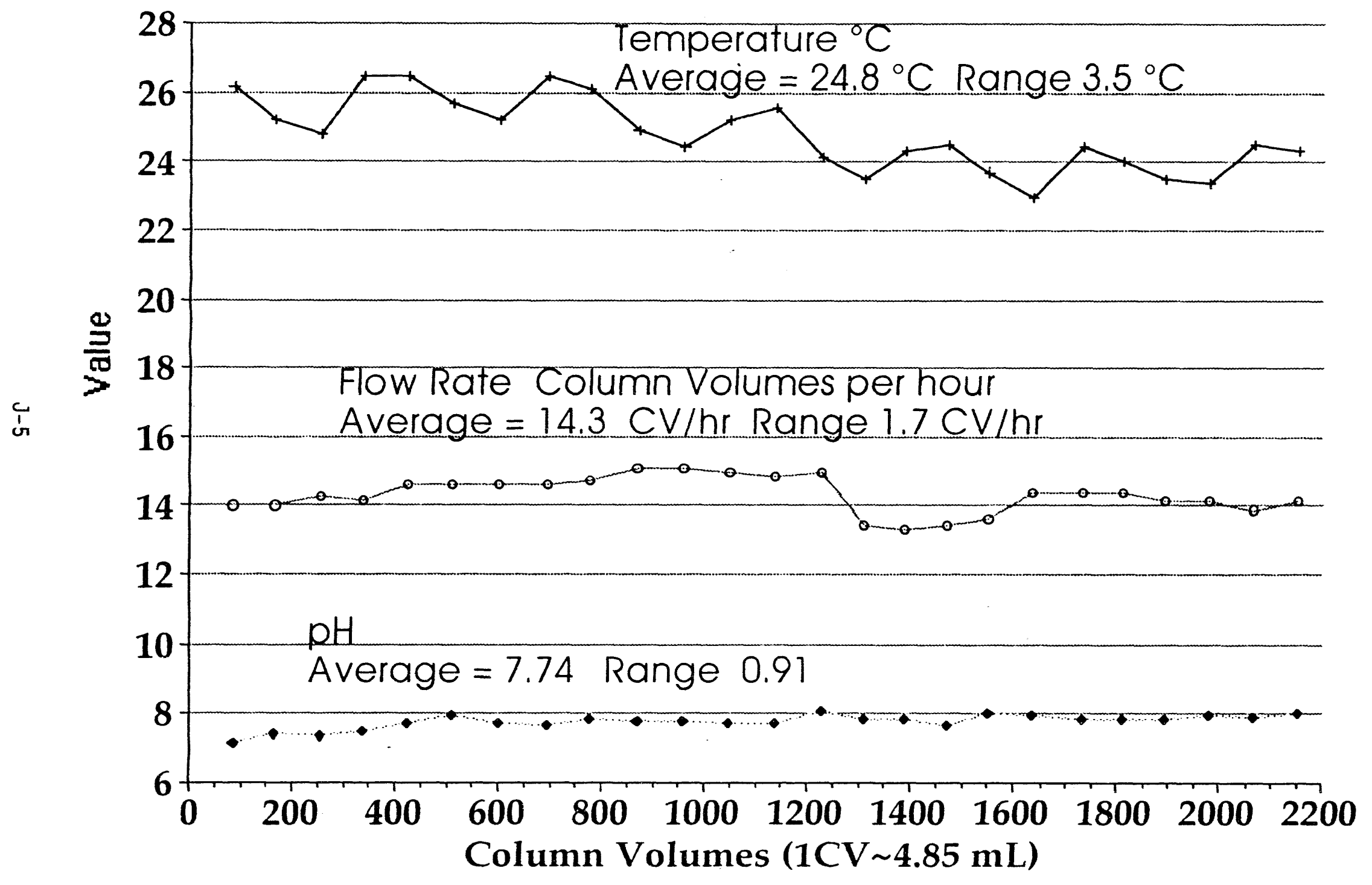


WHC-SD-ER-DTR-001, Rev. 0 


\begin{tabular}{|c|c|c|c|c|c|c|c|c|c|}
\hline $\begin{array}{c}\text { Laboratory } \\
\text { sample\# }\end{array}$ & $\begin{array}{c}\text { Project } \\
\text { sample \# }\end{array}$ & $\begin{array}{c}\text { Cumulative } \\
\text { column } \\
\text { volumes (1 } \\
\text { Column } \\
\text { Volume } \\
-4.85 \mathrm{~mL} \text { ) }\end{array}$ & $\begin{array}{l}\text { Uranium } \\
\text { (ppb) }\end{array}$ & $\begin{array}{c}\text { Total } \\
\text { Chromium } \\
\text { Concentra- } \\
\text { tion (ppb) }\end{array}$ & $\begin{array}{c}\text { Chromium (VI) } \\
\text { Concentration } \\
\text { (ppb) }\end{array}$ & $\begin{array}{c}\text { Nitrate } \\
\text { Concentration } \\
\text { (ppb) }\end{array}$ & $\begin{array}{c}\text { Fiow Rate } \\
\text { (Column } \\
\text { Volumes per } \\
\text { hour) }\end{array}$ & $\begin{array}{l}\text { Temperature } \\
\left({ }^{\circ} \mathrm{C}\right) \text { at end } \\
\text { of sample } \\
\text { collection }\end{array}$ & $\mathrm{pH}$ \\
\hline P 1630. & ERK 19B01 & & 4.3 & 2050.0 & 1990.0 & 50630 & & & 7.8 \\
\hline P 1630 . & ERK 19BO1 & & 6.0 & 2100.0 & 2080.0 & 50630 & & & 7.8 \\
\hline P 1631. & ERK 21T07 & & 925.0 & 2140.0 & 1620.0 & 184600 & & & 8.26 \\
\hline P 1631. & ERK21TO7 & & 660.0 & 2130.0 & 1550.0 & 184700 & & & 8.26 \\
\hline P 1632. & ERK19S01 & 84 & 4.4 & 47.0 & 19.4 & 3473 & 1.13 & 26.2 & 7.17 \\
\hline P 1632. & ERK19SO1 & 84 & 4.6 & 46.0 & 19.4 & 3473 & 1.13 & 26.2 & 7.17 \\
\hline P 1633. & ERK 19502 & 168 & 1.9 & 29.8 & 22.0 & 3473 & 1.13 & 25.2 & 7.39 \\
\hline P 1633. & ERK $19 S 02$ & 168 & 1.9 & 29.8 & 20.7 & 3473 & 1.13 & 25.2 & 7.39 \\
\hline P 1634. & ERK19SO3 & 255 & 6.9 & 29.8 & 19.4 & 3473 & 1.15 & 24.8 & 7.35 \\
\hline P 1634. & ERK19S03 & 255 & 9.5 & 29.8 & 19.4 & 3473 & 1.15 & 24.8 & 7.35 \\
\hline P 1635. & ERK 19SO4 & 338 & 2.0 & 56.0 & 28.5 & 3473 & 1.14 & 26.5 & 7.48 \\
\hline P 1635. & ERK19SO4 & 338 & 2.4 & 46.0 & 32.4 & 3473 & 1.14 & 26.5 & 7.48 \\
\hline P 1636. & ERK 19505 & 425 & 3.9 & 41.0 & 19.4 & 12960 & 1.18 & 26.5 & 7.72 \\
\hline P 1636. & ERK 19505 & 425 & 3.6 & 47.0 & 19.4 & 13200 & 1.18 & 26.5 & 7.72 \\
\hline P 1637. & ERK19SO6 & 510 & 3.8 & 32.0 & 31.1 & 58840 & 1.18 & 25.7 & 7.92 \\
\hline P 1637. & ERK19SO6 & 510 & 4.3 & 34.0 & 27.2 & 58600 & 1.18 & 25.7 & 7.92 \\
\hline P 1638. & ERK 19507 & 601 & 2.1 & 62.0 & 19.4 & 94000 & 1.18 & 25.2 & 7.67 \\
\hline P 1638. & ERK 19507 & 601 & 2.2 & $60: 0$ & 19.4 & 91310 & 1.18 & 25.2 & 7.67 \\
\hline P 1639. & ERK $19 S 08$ & 694 & 4.2 & 39.0 & 31.1 & 67850 & 1.18 & 26.5 & 7.62 \\
\hline P 1639. & ERK 19508 & 694 & 4.0 & 46.0 & 27.2 & 67410 & 1.18 & 26.5 & 7.62 \\
\hline P 1640. & ERK 19509 & 777 & 4.2 & 39.0 & 36.3 & 48000 & 1.19 & 26.1 & 7.81 \\
\hline P 1640. & ERK $19 S 09$ & 777 & 4.4 & 47.0 & 23.3 & 49090 & 1.19 & 26.1 & 7.81 \\
\hline P 1641. & ERK $19 S 10$ & 868 & 3.7 & 70.0 & 37.6 & 46410 & 1.22 & 24.9 & 7.75 \\
\hline P 1641 . & ERK 19510 & 868 & 3.6 & 64.0 & 45.4 & 47290 & 1.22 & 24.9 & 7.75 \\
\hline
\end{tabular}




\begin{tabular}{|c|c|c|c|c|c|c|c|c|c|}
\hline $\begin{array}{l}\text { Laboratory } \\
\text { sample\# }\end{array}$ & $\begin{array}{l}\text { "Project } \\
\text { sample \# }\end{array}$ & $\begin{array}{c}\text { Cumulative } \\
\text { column } \\
\text { volumes (1 } \\
\text { Column } \\
\text { Volume } \\
-4.85 \mathrm{~mL})\end{array}$ & $\begin{array}{c}\text { Uranium } \\
(p p b)\end{array}$ & $\begin{array}{c}\text { Total } \\
\text { Chromium } \\
\text { Concentra- } \\
\text { tion (ppb) }\end{array}$ & $\begin{array}{c}\text { Chromium (VI) } \\
\text { Concentration } \\
\text { (ppb) }\end{array}$ & $\begin{array}{c}\text { Nitrate } \\
\text { Concentration } \\
\text { (ppb) }\end{array}$ & $\begin{array}{c}\text { Flow Rate } \\
\text { (Coiumn } \\
\text { Volumes per } \\
\text { hour) }\end{array}$ & $\begin{array}{l}\text { Temperature } \\
1^{\circ} \mathrm{Cl} \text { at end } \\
\text { of sample } \\
\text { collection }\end{array}$ & $\mathrm{pH}$ \\
\hline P 1642. & ERK19S11 & 958 & 4.2 & 83.0 & 37.6 & 45970 & 1.22 & 24.4 & 7.73 \\
\hline P 1642. & ERK19S11 & 958 & 4.4 & 77.0 & 35.0 & 46330 & 1.22 & 24.4 & 7.73 \\
\hline P 1643. & ERK $19 S 12$ & 1048 & 2.2 & 93.0 & 36.3 & 49240 & 1.21 & 25.2 & 7.71 \\
\hline P 1643. & ERK $19 S 12$ & 1048 & 2.1 & 104.0 & 41.5 & 47010 & 1.21 & 25.2 & 7.71 \\
\hline P 1644. & ERK19S13 & 1138 & 3.9 & 68.0 & 38.9 & 48200 & 1.2 & 25.6 & 7.72 \\
\hline P 1644. & ERK $19 \mathrm{~S} 13$ & 1138 & 3.7 & 60.0 & 45.4 & 49620 & 1.2 & 25.6 & 7.72 \\
\hline P 1645. & ERK $19 S 14$ & 1228 & 15.6 & 145.0 & 77.9 & 47490 & 1.21 & 24.1 & 8.08 \\
\hline P 1645. & ERK19S14 & 1228 & 17.2 & $: 52.0$ & 66.2 & 47540 & 1.21 & 24.1 & 8.08 \\
\hline P 1646. & ERK19S15 & 1309 & 4.2 & 171.0 & 75.3 & 46230 & 1.09 & 23.5 & 7.82 \\
\hline P 1646. & ERK $19 S 15$ & 1309 & 3.9 & 167.0 & 77.7 & 45770 & 1.09 & 23.5 & 7.82 \\
\hline P 1647. & ERK $19 S 16$ & 1390 & 2.0 & 188.0 & 84.4 & 46330 & 1.08 & 24.3 & 7.79 \\
\hline P 1647. & ERK $19 S 16$ & 1390 & 1.9 & 188.0 & 83.1 & 46610 & 1.08 & 24.3 & 7.79 \\
\hline P 1648. & ERK19S17 & 1470 & 4.0 & 197.0 & 96.1 & 47390 & 1.09 & 24.5 & 7.72 \\
\hline P 1648. & ERK $19 S 17$ & 1470 & 3.9 & 199.0 & 92.2 & 47120 & 1.09 & 24.5 & 7.72 \\
\hline P 1649. & ERK $19 S 18$ & 1552 & 4.4 & 225.0 & 131.0 & 47370 & 1.1 & 23.7 & 7.64 \\
\hline P 1649. & ERK19S18 & 1552 & 4.2 & 223.0 & 125.0 & 47430 & 1.1 & 23.7 & 7.64 \\
\hline P 1650. & ERK $19 S 19$ & 1638 & 9.1 & 258.0 & 155.0 & 46890 & 1.16 & 23 & 8.02 \\
\hline P 1650. & ERK $19 S 19$ & 1638 & 8.3 & 254.0 & 160.0 & 47330 & 1.16 & 23 & 8.02 \\
\hline P 1651. & ERK $19 S 20$ & 1733 & 3.9 & 180.0 & 197.0 & 47570 & 1.16 & 24.4 & 7.93 \\
\hline P 1651. & ERK $19 S 20$ & 1733 & 3.6 & 178.0 & 183.0 & 47620 & 1.16 & 24.4 & 7.93 \\
\hline P 1652. & ERK $19 S 21$ & 1811 & 7.8 & 221.0 & 208.0 & 47140 & 1.16 & 24 & 7.82 \\
\hline P 1652. & ERK 19S21 & 1811 & 6.2 & 216.0 & 221.0 & 48440 & 1.16 & 24 & 7.82 \\
\hline P 1653. & ERK $19 S 22$ & 1896 & 4.2 & 234.0 & 246.0 & 47630 & 1.14 & 23.5 & 7.81 \\
\hline P 1653. & ERK19S22 & 1896 & 4.0 & 232.0 & 239.0 & 47760 & 1.14 & 23.5 & 781 \\
\hline
\end{tabular}




\begin{tabular}{|c|c|c|c|c|c|c|c|c|c|}
\hline $\begin{array}{c}\text { Laboratory } \\
\text { sample: }\end{array}$ & $\begin{array}{l}\text { Project } \\
\text { sample }\end{array}$ & $\begin{array}{c}\text { Cumulative } \\
\text { column } \\
\text { volumes (1 } \\
\text { Column } \\
\text { volume } \\
-4.85 \mathrm{~mL} \text { ) }\end{array}$ & $\begin{array}{c}\text { Uranium } \\
\text { (ppb) }\end{array}$ & $\begin{array}{c}\text { Total } \\
\text { Chromium } \\
\text { Concentra- } \\
\text { tion (ppb) }\end{array}$ & $\begin{array}{c}\text { Chromium (VI) } \\
\text { Concentration } \\
\text { (ppb) }\end{array}$ & $\begin{array}{l}\text { Nitrato } \\
\text { Concentrazion } \\
\text { (ppb) }\end{array}$ & $\begin{array}{c}\text { Flow Rate } \\
\text { IColumn } \\
\text { Volumes por } \\
\text { hour) }\end{array}$ & $\begin{array}{l}\text { Temperature } \\
{ }^{\circ} \mathrm{C} \text { at end } \\
\text { of sample } \\
\text { collection }\end{array}$ & pH \\
\hline P 1654. & ERK $19 \mathrm{~S} 23$ & 1981 & 4.6 & 262.0 & 253.0 & 47600 & 1.14 & 23.4 & 7.79 \\
\hline P 1654. & ERK $19 \mathrm{~S} 23$ & 1981 & 3.8 & 260.0 & 255.0 & 47480 & 1.14 & 23.4 & 7.79 \\
\hline P 1655. & ERK 19S 24 & 2064 & 17.5 & 297.0 & 298.0 & 48530 & 1.12 & 24.5 & 7.94 \\
\hline P 1655. & ERK19S24 & 2064 & 15.2 & 300.0 & 294.0 & 47740 & 1.12 & 24.5 & 7.94 \\
\hline P 1656. & ERK19S25 & 2149 & 11.6 & 331.0 & 303.0 & 48110 & 1.14 & 24.3 & 7.89 \\
\hline P 1656. & ERK19S25 & 2149 & 10.0 & 329.0 & 304.0 & 46910 & 1.14 & 24.3 & 7.89 \\
\hline P 1657. & ERK $; 9 B 02$ & & 20.0 & 1970.0 & 1830.0 & 49120 & & & 7.97 \\
\hline P 1657. & ERK19BO2 & & 19.5 & 1980.0 & 1820.0 & 48460 & & & 7.97 \\
\hline
\end{tabular}


WHC-SD-ER-DTR-001, Rev. 0

\begin{abstract}
APPENDIX K
RESULTS OF THE BIODENITRIFIED GROUNDWATER (WELLS 199-H4-4 AND 199-D5-15)
\end{abstract} BREAKTHROUGH TEST 
WHC-SD-ER-DTR-001, Rev. 0

K-2 


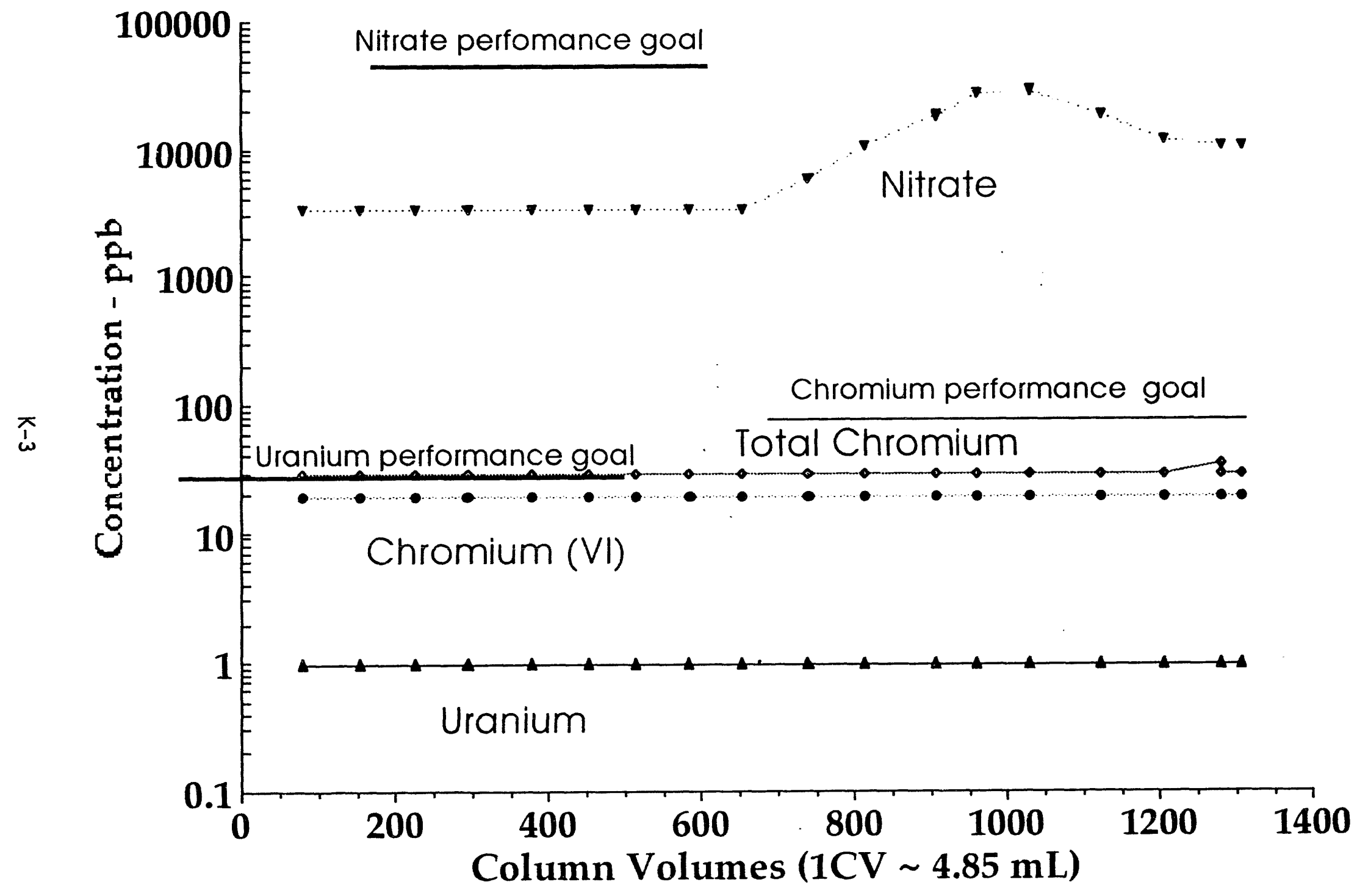

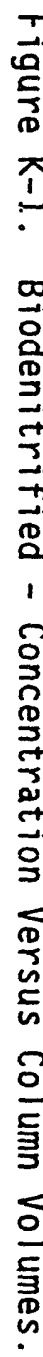




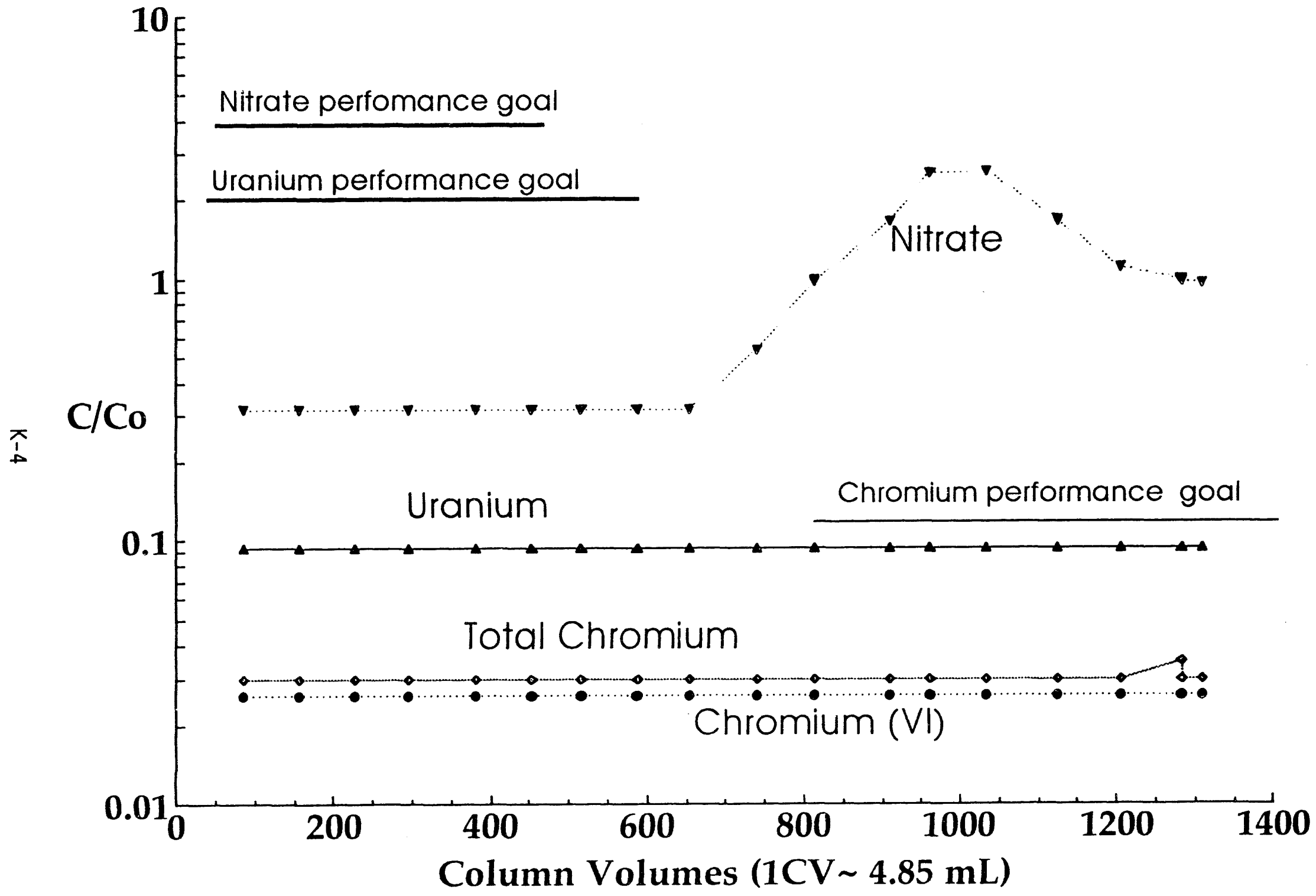




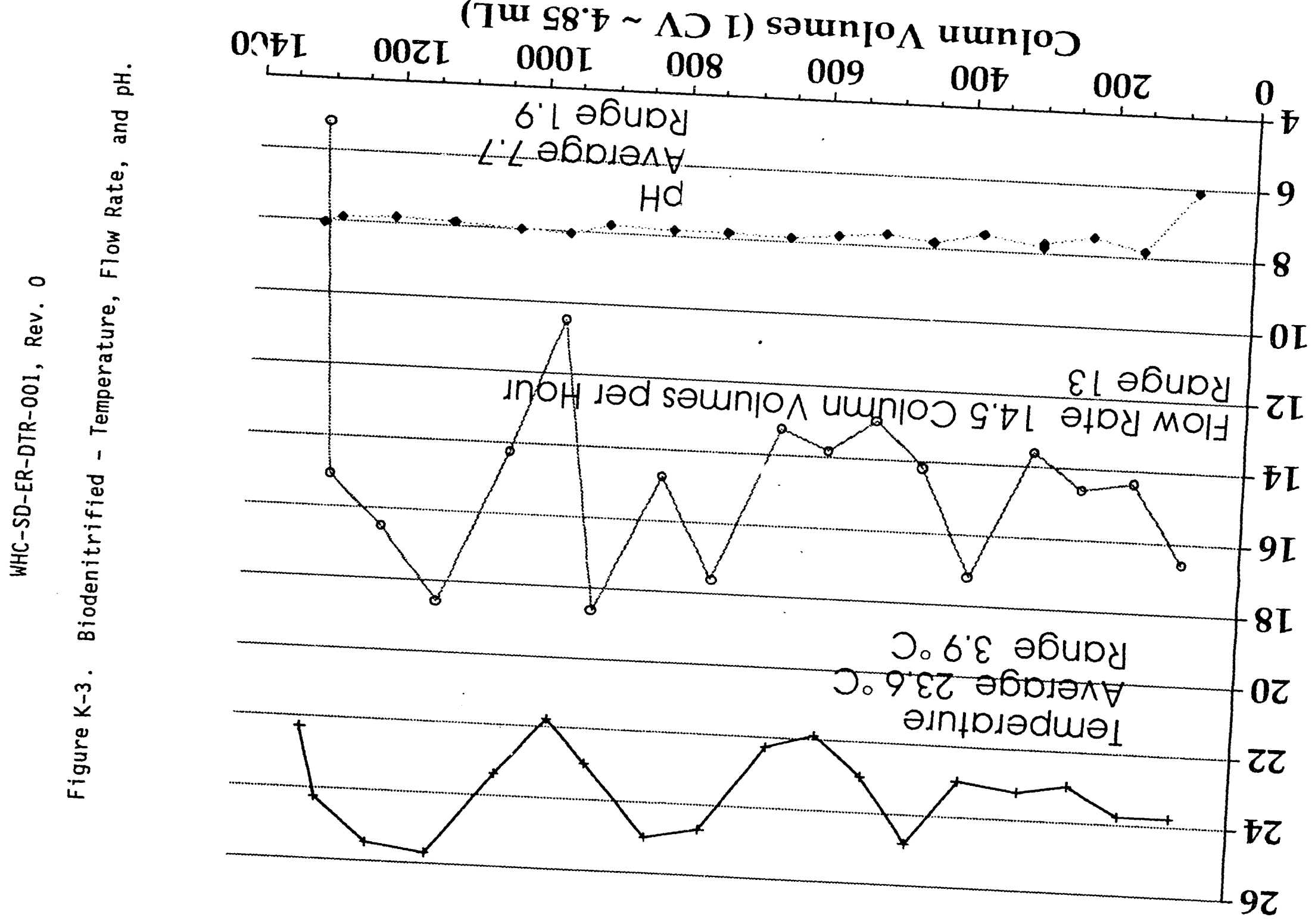


WHC-SD-ER-DTR-001, Rev. 0 


\begin{tabular}{|c|c|c|c|c|c|c|c|c|c|}
\hline $\begin{array}{l}\text { Laboratory } \\
\text { sample }\end{array}$ & $\begin{array}{c}\text { Project } \\
\text { sample \# }\end{array}$ & $\begin{array}{l}\text { Cumulative Column } \\
\text { Volumes (1 } \\
\text { Column volume - } \\
4.85 \mathrm{~mL} \text { ) }\end{array}$ & $\begin{array}{c}\text { Uranium } \\
\text { Concentration } \\
(\mathrm{ppb})\end{array}$ & $\begin{array}{c}\text { Total } \\
\text { Chromium } \\
\text { Concentration } \\
\text { (ppb) }\end{array}$ & $\begin{array}{c}\text { Chromium } \\
\text { (VI) } \\
\text { Concentration } \\
\text { (ppb) }\end{array}$ & $\begin{array}{c}\text { Nitrate } \\
\text { Concentration } \\
\text { (ppb) }\end{array}$ & $\begin{array}{c}\text { Temperature } \\
1^{\circ} \mathrm{Cl} \text { at end of } \\
\text { sample } \\
\text { collection }\end{array}$ & $\begin{array}{c}\text { Flow Rate } \\
\text { (Column } \\
\text { Volumes per } \\
\text { Hour) }\end{array}$ & $\mathrm{pH}$ \\
\hline P 1695. & ERK 21T11 & & 788 & 2180 & 1800 & 218570 & & & 000011 \\
\hline P 1695. & ERK $21 T 11$ & & 804 & 2160 & 1760 & 219480 & & & 4.33 \\
\hline P 1696. & ERK $30 B 01$ & & 10.8 & 1000 & 720 & 11060 & & & 7.99 \\
\hline P 1696. & ERK $30 B 01$ & & 10.8 & 1010 & 694 & 11020 & & & 84 \\
\hline P 1697. & ERK30SO1 & 83.1 & 1 & 29.8 & 19.4 & 3473 & 23.8 & 16.6 & 6.12 \\
\hline P 1697. & ERK30S01 & 83.1 & 1 & 29.8 & 19.4 & 3473 & 23.8 & 16.6 & 6.12 \\
\hline P 1698. & ERK30S02 & 154.6 & 1 & 29.8 & 19.4 & 3473 & 23.8 & 14.4 & 7.81 \\
\hline P 1698. & ERK30SO2 & 154.6 & 1 & 29.8 & 19.4 & 3473 & 23.8 & 14.4 & 7.81 \\
\hline P 1699. & ERK30SO3 & 227.4 & 1 & 29.8 & 19.4 & 3473 & 23 & 14.6 & 7.49 \\
\hline P 1699. & ERK $30 \mathrm{SO} 3$ & 227.4 & 1 & 29.8 & 19.4 & 3473 & 23 & 14.6 & 7.49 \\
\hline P 1700. & ERK30S04 & 295.5 & 1 & 29.8 & 19.4 & 3473 & 23.2 & 13.6 & 7.74 \\
\hline P 1700. & ERK30SO4 & 295.5 & 1 & 29.8 & 19.4 & 3473 & 23.2 & 13.6 & 7.84 \\
\hline P 1701. & ERK 30505 & 381.4 & 1 & 29.8 & 19.4 & 3473 & 23 & 17.2 & 7.52 \\
\hline P 1701. & ERK30SO5 & 381.4 & 1 & 29.8 & 19.4 & 3473 & 23 & 17.2 & 7.52 \\
\hline P 1702. & ERK30S06 & 452.2 & 1 & 29.8 & 19.4 & 3473 & 24.8 & 14.2 & 7.84 \\
\hline P 1702 . & ERK30S06 & 452.2 & 1 & 29.8 & 19.4 & 3473 & 24.8 & 14.2 & 7.84 \\
\hline P 1703. & ERK30S07 & 516.9 & 1 & 29.8 & 19.4 & 3473 & 23 & 12.9 & 7.63 \\
\hline P 1703. & ERK30S07 & 516.9 & 1 & 29.8 & 19.4 & 3473 & 23 & 12.9 & 7.63 \\
\hline P 1704. & ERK 30508 & 586.1 & 1 & 29.8 & 19.4 & 3473 & 21.9 & 13.8 & 7.78 \\
\hline P 1704. & ERK 30508 & 586.1 & 1 & 29.8 & 19.4 & 3473 & 21.9 & 13.8 & 7.78 \\
\hline P 1705. & ERK30SO9 & 652.3 & 1 & 29.8 & 19.4 & 3473 & 22.3 & 13.2 & 7.9 \\
\hline P 1705. & ERK30SO9 & 652.3 & 1 & 29.8 & 19.4 & 3473 & 22.3 & 13.2 & 7.9 \\
\hline P 1706. & ERK $30 S 10$ & 740.3 & 1 & 29.8 & 19.4 & 5891 & 24.7 & 17.6 & 7.82 \\
\hline P 1706. & ERK $30 S 10$ & 740.3 & 1 & 29.8 & 19.4 & 5899 & 24.7 & 17.6 & 7.82 \\
\hline P 1707. & ERK $30 S 11$ & 814 & 1 & 29.8 & 19.4 & 10812 & 25 & 14.7 & 7.82 \\
\hline
\end{tabular}




\begin{tabular}{|c|c|c|c|c|c|c|c|c|c|}
\hline $\begin{array}{l}\text { Laboratory } \\
\text { sample \# }\end{array}$ & $\begin{array}{l}\text { Project } \\
\text { sample }\end{array}$ & $\begin{array}{l}\text { Cumulative Column } \\
\text { Volumes (1 } \\
\text { Column volume - } \\
4.85 \mathrm{~mL} \text { ) }\end{array}$ & $\begin{array}{c}\text { Uranium } \\
\text { Concentration } \\
\text { (ppb) }\end{array}$ & $\begin{array}{c}\text { Total } \\
\text { Chromium } \\
\text { Concentration } \\
\text { (ppb) }\end{array}$ & $\begin{array}{c}\text { Chromium } \\
\text { (VI) } \\
\text { Concentration } \\
\text { (ppb) }\end{array}$ & $\begin{array}{l}\text { Nitrate } \\
\text { Concentration } \\
\text { (ppb) }\end{array}$ & $\begin{array}{l}\text { Temperature } \\
\left(^{\circ} \mathrm{Cl} \text { at end of }\right. \\
\text { sample } \\
\text { collection }\end{array}$ & $\begin{array}{l}\text { Flow Rate } \\
\text { (Column } \\
\text { Volumes per } \\
\text { Hour) }\end{array}$ & $\mathrm{pH}$ \\
\hline P 1707. & ERK30S11 & 814 & 1 & 29.8 & 19.4 & 10715 & 25 & 14.7 & 7.82 \\
\hline P 1708. & ERK30S 12 & 907.1 & 1 & 29.8 & 19.4 & 18239 & 23 & 18.6 & 7.8 \\
\hline P 1708. & ERK $30 S 12$ & 907.1 & 1 & 29.8 & 19.4 & 18000 & 23 & 18.6 & 7.8 \\
\hline P 1709. & ERK $30 S 13$ & 959.3 & 1 & 29.8 & 19.4 & 27468 & 21.8 & 10.4 & 85 \\
\hline P 1709. & ERK3OS 13 & 959.3 & 1 & 29.8 & 19.4 & 27606 & 21.8 & 10.4 & 85 \\
\hline P 1710. & ERK30S 14 & 1030.5 & 1 & 29.8 & 19.4 & 27934 & 23.4 & 14.2 & 82 \\
\hline P 1710. & ERK $30 S 14$ & 1030.5 & 1 & 29.8 & 19.4 & 28137 & 23.4 & 14.2 & 82 \\
\hline P 1711. & ERK30S15 & 1123.4 & 1 & 29.8 & 19.4 & 18379 & 25.7 & 18.6 & 7.89 \\
\hline P 1711. & ERK $30 S 15$ & 1123.4 & 1 & 29.8 & 19.4 & 18232 & 25.7 & 18.6 & 7.89 \\
\hline P 1712. & ERK30S 16 & 1205.9 & 1 & 29.8 & 19.4 & 12046 & 25.5 & 16.5 & 7.83 \\
\hline P 1712. & ERK30S16 & 1205.9 & 1 & 29.8 & 19.4 & 12101 & 25.5 & 16.5 & 7.83 \\
\hline P 1713. & ERK30S17 & 1281.2 & 1 & 35 & 19.4 & 10872 & 24.2 & 15.1 & 7.88 \\
\hline P 1713. & ERK30S17 & 1281.2 & 1 & 30 & 19.4 & 10689 & 24.2 & 15.1 & 7.88 \\
\hline P 1714. & ERK30S 18 & 1307.3 & 1 & 29.8 & 19.4 & 10560 & 22.3 & 5.2 & 85 \\
\hline P 1714. & ERK 30518 & 1307.3 & 1 & 29.8 & 19.4 & 10560 & 22.3 & 5.2 & 85 \\
\hline P 1722. & ERK 30802 & & 10.1 & 998 & 787 & 10740 & & & 85 \\
\hline P 1722. & ERK 30802 & & 10.5 & 995 & 814 & 10830 & & & 85 \\
\hline
\end{tabular}


WHC-SD-ER-DTR-001, Rev. 0

APPENDIX L

RESULTS OF THE LOW FLOW RATE VERY HIGH SPIKED GROUNDWATER (WELL 199-H3-2C) BREAKTHROUGH TEST 
WHC-SD-ER-DTR-001, Rev. 0 


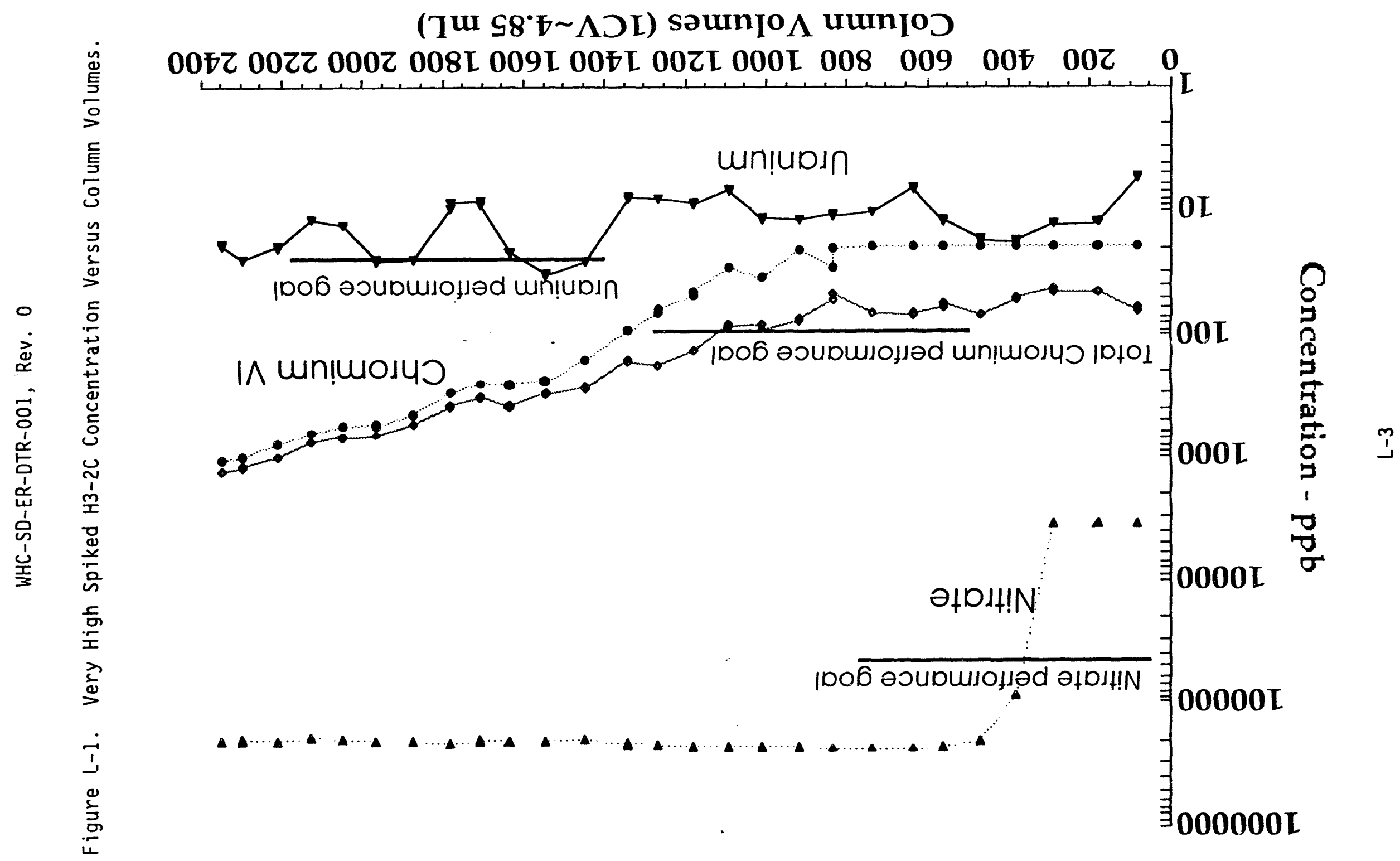




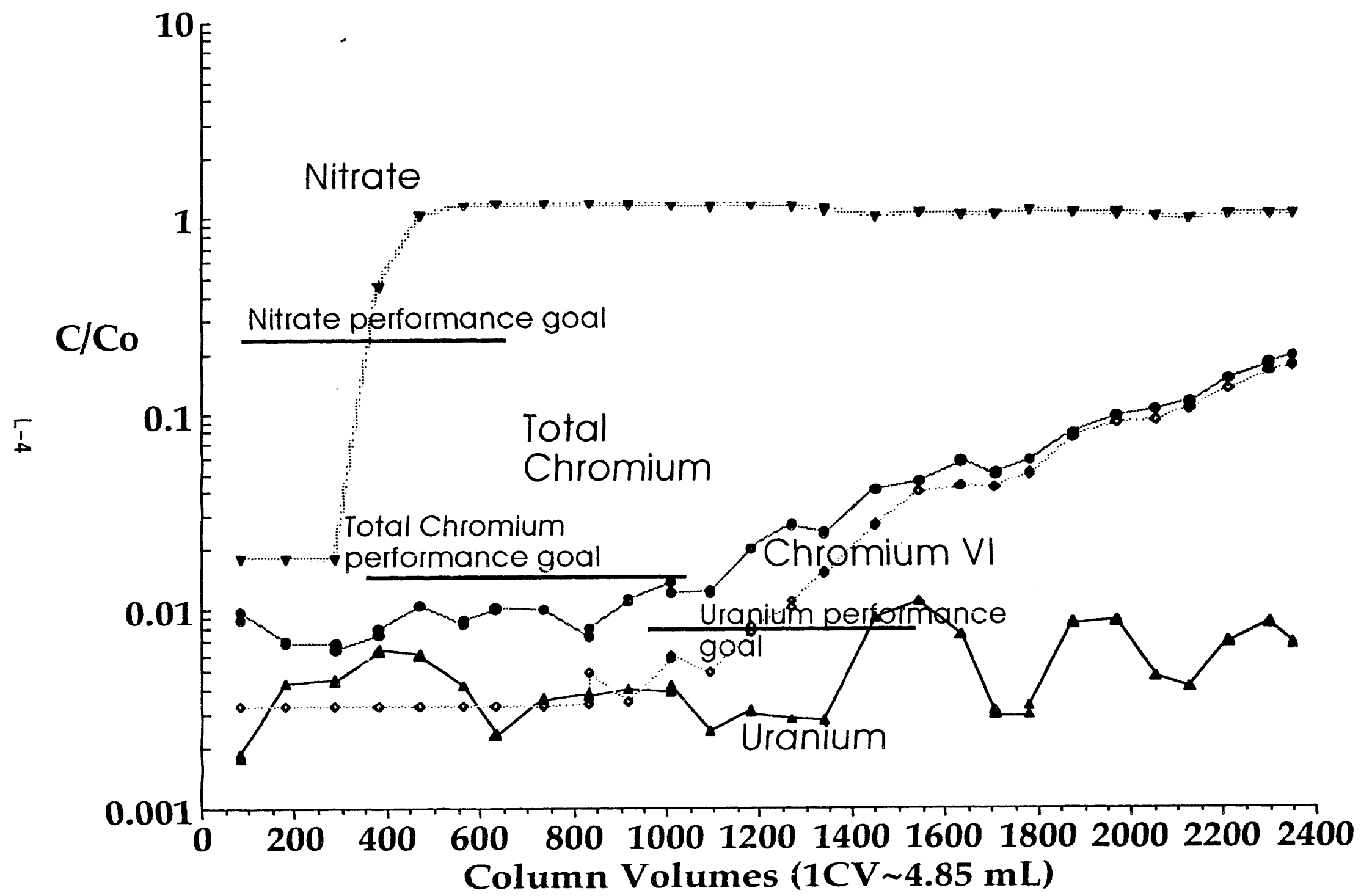

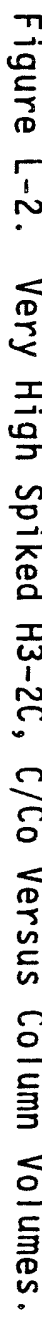

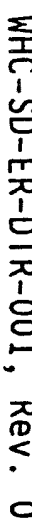




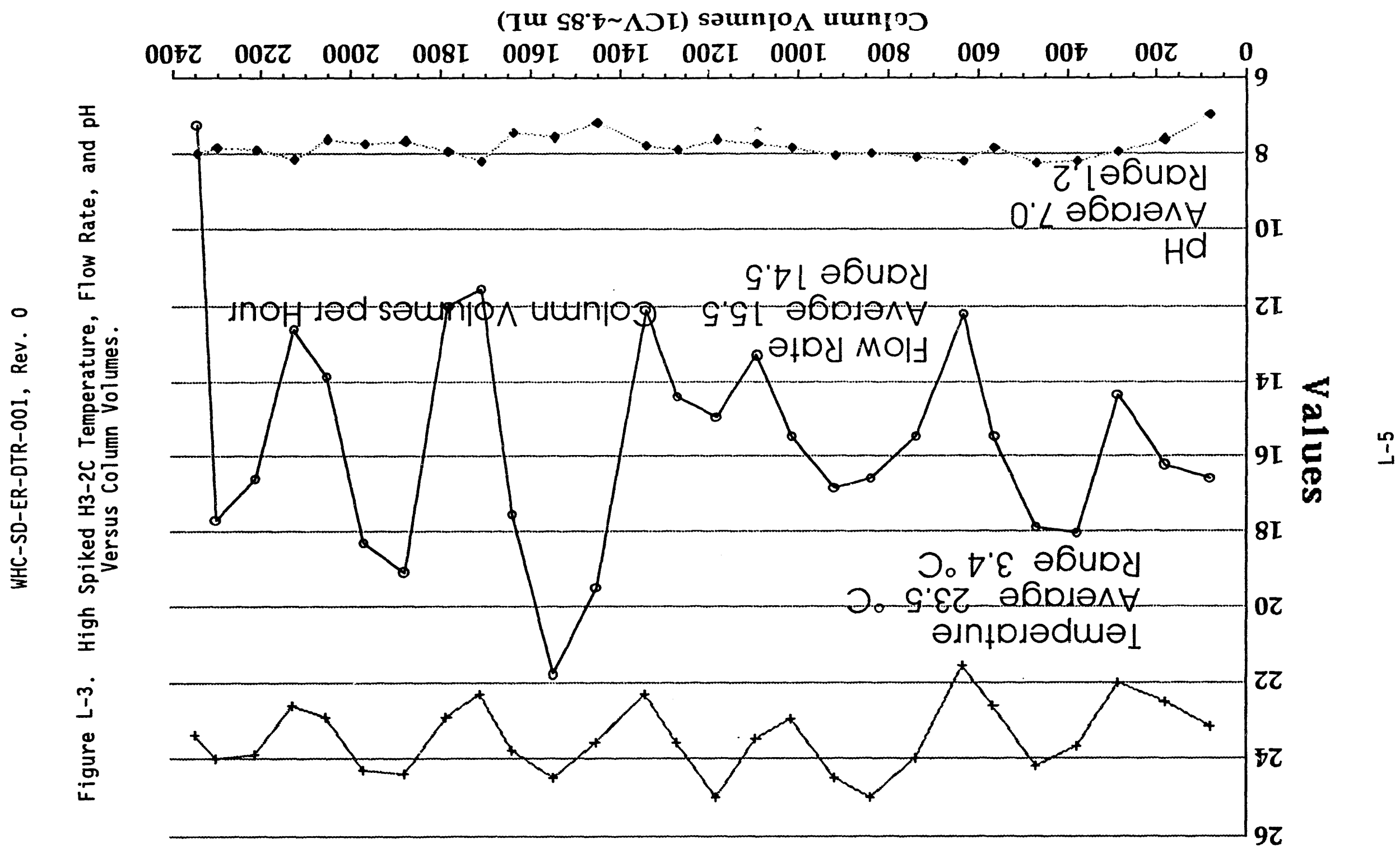


WHC-SD-ER-DTR-001, Rev. 0 


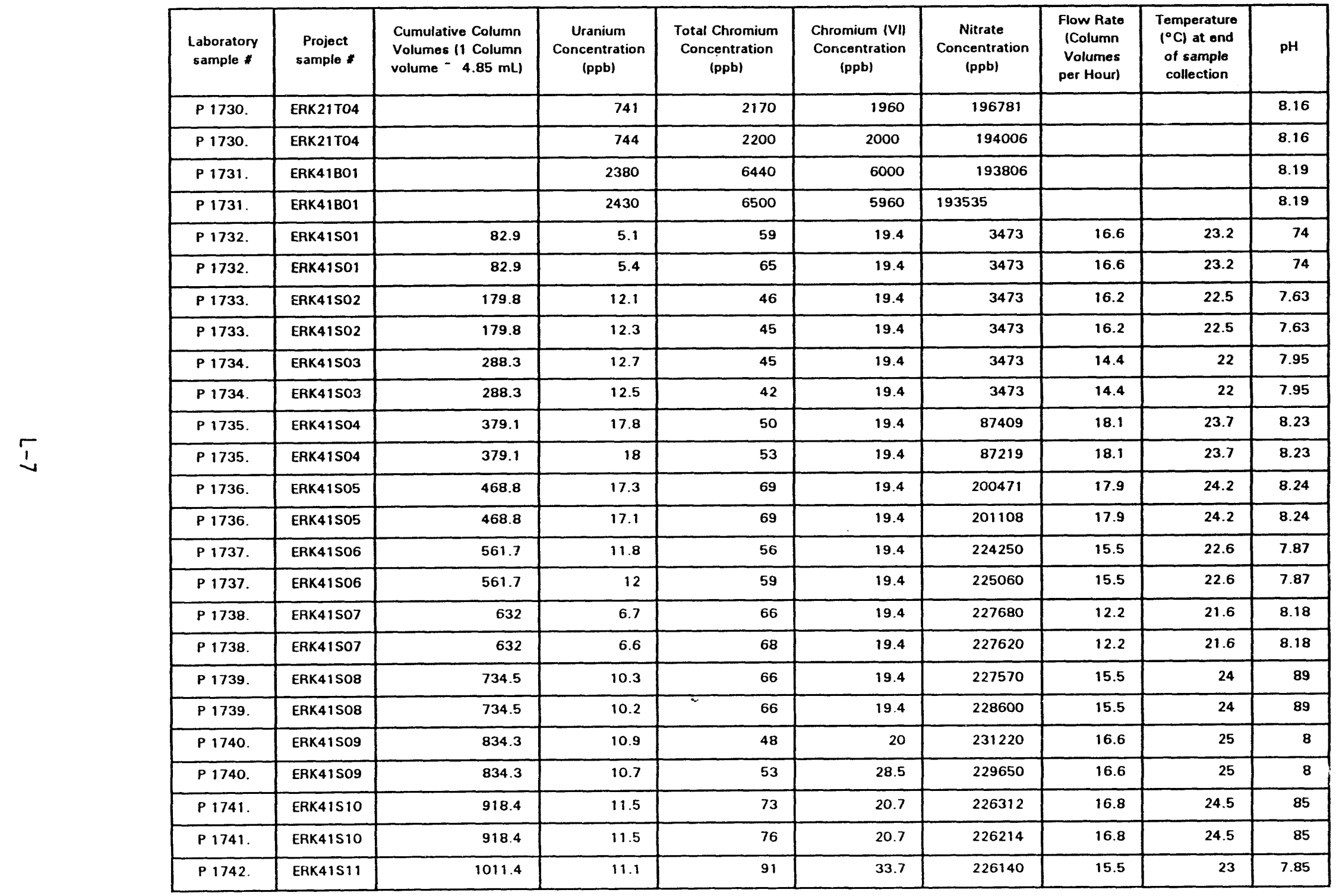




\begin{tabular}{|c|c|c|c|c|c|c|c|c|c|}
\hline $\begin{array}{l}\text { Laboratory } \\
\text { sample \# }\end{array}$ & $\begin{array}{l}\text { Project } \\
\text { sample }\end{array}$ & $\begin{array}{l}\text { Cumulative Column } \\
\text { Volumes (1 Column } \\
\text { volume- } 4.85 \mathrm{~mL})\end{array}$ & $\begin{array}{c}\text { Uranium } \\
\text { Concentration } \\
\text { (ppb) }\end{array}$ & $\begin{array}{c}\text { Total Chromium } \\
\text { Concentration } \\
\text { (ppb) }\end{array}$ & $\begin{array}{l}\text { Chromium (VI) } \\
\text { Concentration } \\
\text { (ppb) }\end{array}$ & $\begin{array}{c}\text { Nitrate } \\
\text { Concentration } \\
\text { (ppb) }\end{array}$ & $\begin{array}{l}\text { Flow Rate } \\
\text { (Column } \\
\text { Volumes } \\
\text { per Hour) }\end{array}$ & $\begin{array}{l}\text { Temperature } \\
\left({ }^{\circ} \mathrm{C}\right) \text { at end } \\
\text { of sample } \\
\text { collection }\end{array}$ & $\mathrm{pH}$ \\
\hline P 1742. & ERK41S11 & 1011.4 & 11.8 & 82 & 35 & 223470 & 15.5 & 23 & 7.85 \\
\hline P 1743. & ERK41S12 & 1091.3 & 7 & 83 & 28.5 & 220170 & 13.3 & 23.5 & 7.75 \\
\hline P 1743. & ERK41S12 & 1091.3 & 6.9 & 81 & 28.5 & 222060 & 13.3 & 23.5 & 7.75 \\
\hline P 1744. & ERK41S13 & 1181.3 & 8.9 & .134 & 45.4 & 221280 & 15 & 25 & 7.66 \\
\hline P 1744. & ERK $41 S 13$ & 1181.3 & 8.6 & 135 & 49.3 & 223010 & 15 & 25 & 7.66 \\
\hline P 1745. & ERK $41 S 14$ & 1267.9 & 8 & 180 & 61 & 218416 & 14.4 & 23.6 & 7.89 \\
\hline P 1745. & ERK41S14 & 1267.9 & 8 & 177 & 66.2 & 216241 & 14.4 & 23.6 & 7.89 \\
\hline P 1746. & ERK41S15 & 1341.2 & 7.8 & 164 & 92.2 & 210506 & 12.1 & 22.3 & 7.79 \\
\hline P 1746. & ERK41S15 & 1341.2 & 7.9 & 159 & 90.9 & 212082 & 12.1 & 22.3 & 7.79 \\
\hline P 1747. & ERK41S16 & 1450 & 25.7 & 278 & 160 & 191980 & 19.5 & 23.6 & 7.21 \\
\hline P 1747. & ERK41S16 & 1450 & 25.8 & 272 & 162 & 192360 & 19.5 & 23.6 & 7.21 \\
\hline P 1748. & ERK41S17 & 1546.3 & 32.1 & 305 & 239 & 202730 & 21.8 & 24.5 & 7.57 \\
\hline P 1748. & ERK 41517 & 1546.3 & 30.9 & 300 & 235 & 201590 & 21.8 & 24.5 & 7.57 \\
\hline P 1749. & ERK41S18 & 1634.2 & 21.4 & 378 & 255 & 200520 & 17.6 & 23.8 & 7.5 \\
\hline P 1749. & ERK41S18 & 1634.2 & 21.6 & 385 & 260 & 200420 & 17.6 & 23.8 & 7.5 \\
\hline P 1750. & ERK41S19 & 1707.6 & 9 & 323 & 251 & 197090 & 11.5 & 22.3 & 8.19 \\
\hline P 1750. & ERK41S 19 & 1707.6 & 8.4 & 330 & 255 & 198310 & 11.5 & 22.3 & 8.19 \\
\hline P 1751. & ERK41S20 & 1779.6 & 8.5 & 383 & 300 & 208316 & 12 & 22.9 & 7.94 \\
\hline P 1751. & ERK41S20 & 1779.6 & 9.4 & 386 & 296 & 208747 & 12 & 22.9 & 7.94 \\
\hline P 1752. & ERK41S21 & 1875.1 & 24.9 & 529 & 448 & 201840 & 19.1 & 24.4 & 7.69 \\
\hline P 1752. & ERK41S21 & 1875.1 & 24.3 & 536 & 452 & 201860 & 19.1 & 24.4 & 7.69 \\
\hline P 1753. & ERK41S22 & 1966.9 & 25.6 & 646 & 545 & 197997 & 18.3 & 24.3 & 7.75 \\
\hline P 1753. & ERK41S22 & 1966.9 & 24.5 & 646 & 541 & 201389 & 18.3 & 24.3 & 7.75 \\
\hline P 1754. & ERK41S23 & 2050.4 & 13.2 & 693 & 547 & 195848 & 13.9 & 22.9 & 7.66 \\
\hline P 1754. & ERK41S23 & 2050.4 & 13.1 & 687 & 551 & 196365 & 13.9 & 22.9 & 7.66 \\
\hline P 1755. & ERK41S24 & 2126.5 & 11.7 & 749 & 632 & 188500 & 12.6 & 22.6 & 8.15 \\
\hline
\end{tabular}




\begin{tabular}{|c|c|c|c|c|c|c|c|c|c|}
\hline $\begin{array}{l}\text { Laboratory } \\
\text { samplo * }\end{array}$ & $\begin{array}{l}\text { Projoct } \\
\text { sample : }\end{array}$ & $\begin{array}{l}\text { Cumulativo Column } \\
\text { Volumes (1 Column } \\
\text { volume- } 4.85 \mathrm{~mL})\end{array}$ & $\begin{array}{c}\text { Uranium } \\
\text { Concontration } \\
\text { (ppb) }\end{array}$ & $\begin{array}{c}\text { Total Chromium } \\
\text { Concentration } \\
\text { (ppb) }\end{array}$ & $\begin{array}{l}\text { Chromium (VI) } \\
\text { Concentration } \\
\text { (ppb) }\end{array}$ & $\begin{array}{c}\text { Nitrate } \\
\text { Concentration } \\
\text { (ppb) }\end{array}$ & $\begin{array}{l}\text { Flow Rate } \\
\text { (Column } \\
\text { Volumes } \\
\text { per Hour) }\end{array}$ & $\begin{array}{l}\text { Tomperature } \\
\left({ }^{\circ} \mathrm{C}\right) \text { at ond } \\
\text { of samplo } \\
\text { collection }\end{array}$ & pH \\
\hline P 1755 . & ERK41S24 & 2126.5 & 11.6 & 744 & 627 & 190123 & 12.6 & 22.6 & 8.15 \\
\hline P 1756. & ERK41S25 & 2209.7 & 20.1 & 981 & 779 & 198459 & 16.6 & 23.9 & 7.91 \\
\hline P 1756. & ERK41S25 & 2209.7 & 19.7 & 978 & 784 & 200919 & 16.6 & 23.9 & 7.91 \\
\hline P 1757. & ERK41S26 & 2298.2 & 24.9 & 1180 & 976 & 197562 & 17.7 & 24 & 7.83 \\
\hline P 1757. & ERK41526 & 2298.2 & 24.4 & 1200 & 982 & 200155 & 17.7 & 24 & 7.83 \\
\hline P 1758. & ERK41S27 & 2347.5 & 19.5 & 1290 & 1050 & 199296 & 7.3 & 23.4 & 7.99 \\
\hline P 1, 58. & ERK41S27 & 2347.5 & 19.1 & 1290 & 1060 & 198917 & 7.3 & 23.4 & 7.99 \\
\hline P 1762. & ERK41BO2 & & 3297 & 6720 & 5880 & 194280 & & & 7.62 \\
\hline P 1762. & ERK41BO2 & & 3276 & 6650 & 5840 & 195296 & & & 7.62 \\
\hline P 1763. & ERK31TO5 & & 805 & 2260 & 1980 & 191124 & & & 7.63 \\
\hline P 1763. & ERK31T05 & & 801 & 2250 & 2000 & 194087 & & & 7.63 \\
\hline
\end{tabular}


WHC-SD-ER-DTR-001, Rev. 0 
WHC-SD-ER-DTR-001, Rev. 0

\section{APPENDIX $M$}

CYCLING TEST

M-1 
WHC-SD-ER-DTR-001, Rev. 0 
WHC-SD-ER-DTR-001, Rev. 0

Figure M-1. Cycling Test, Treated Effluent Concentration Versus Column Volumes.

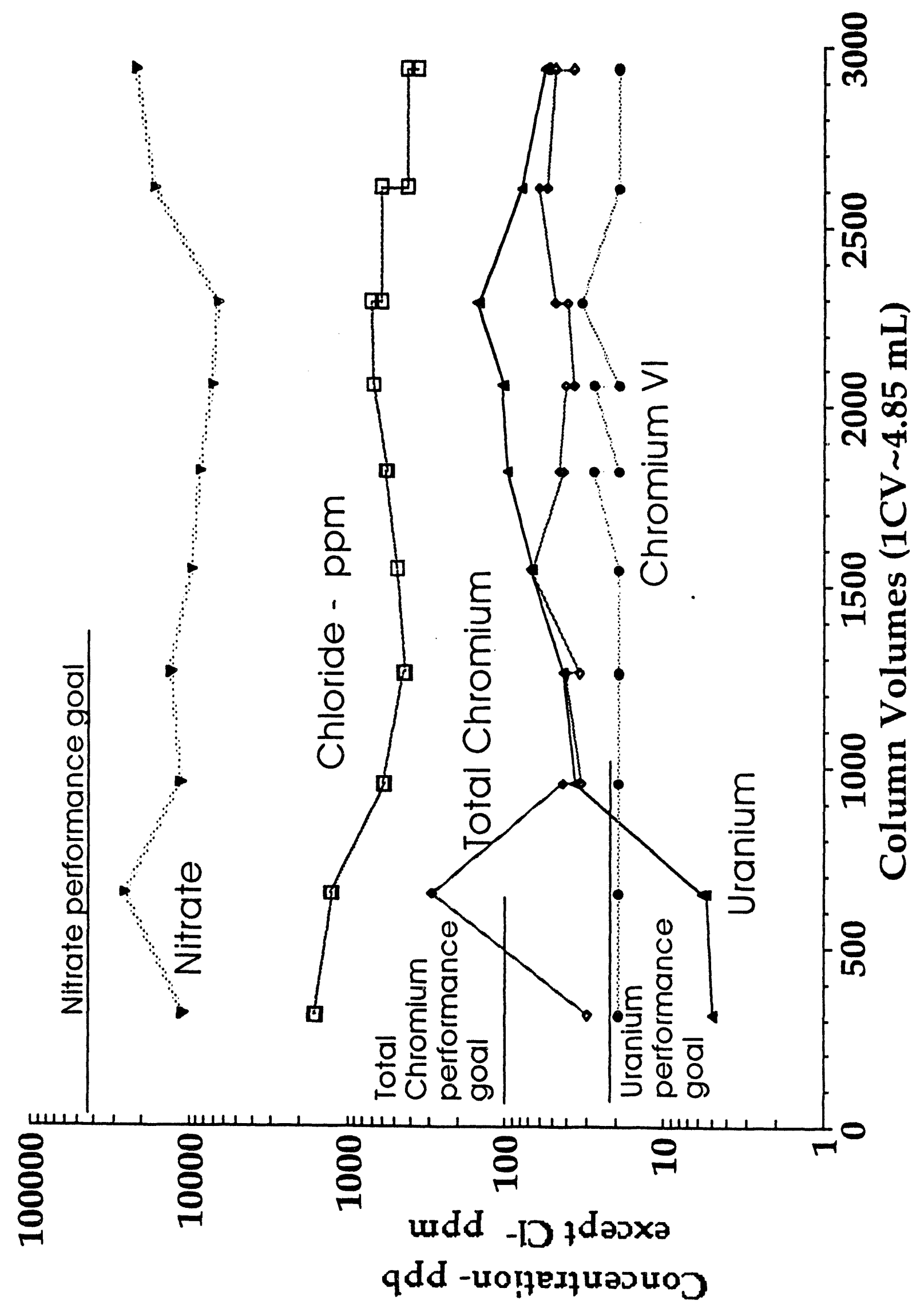




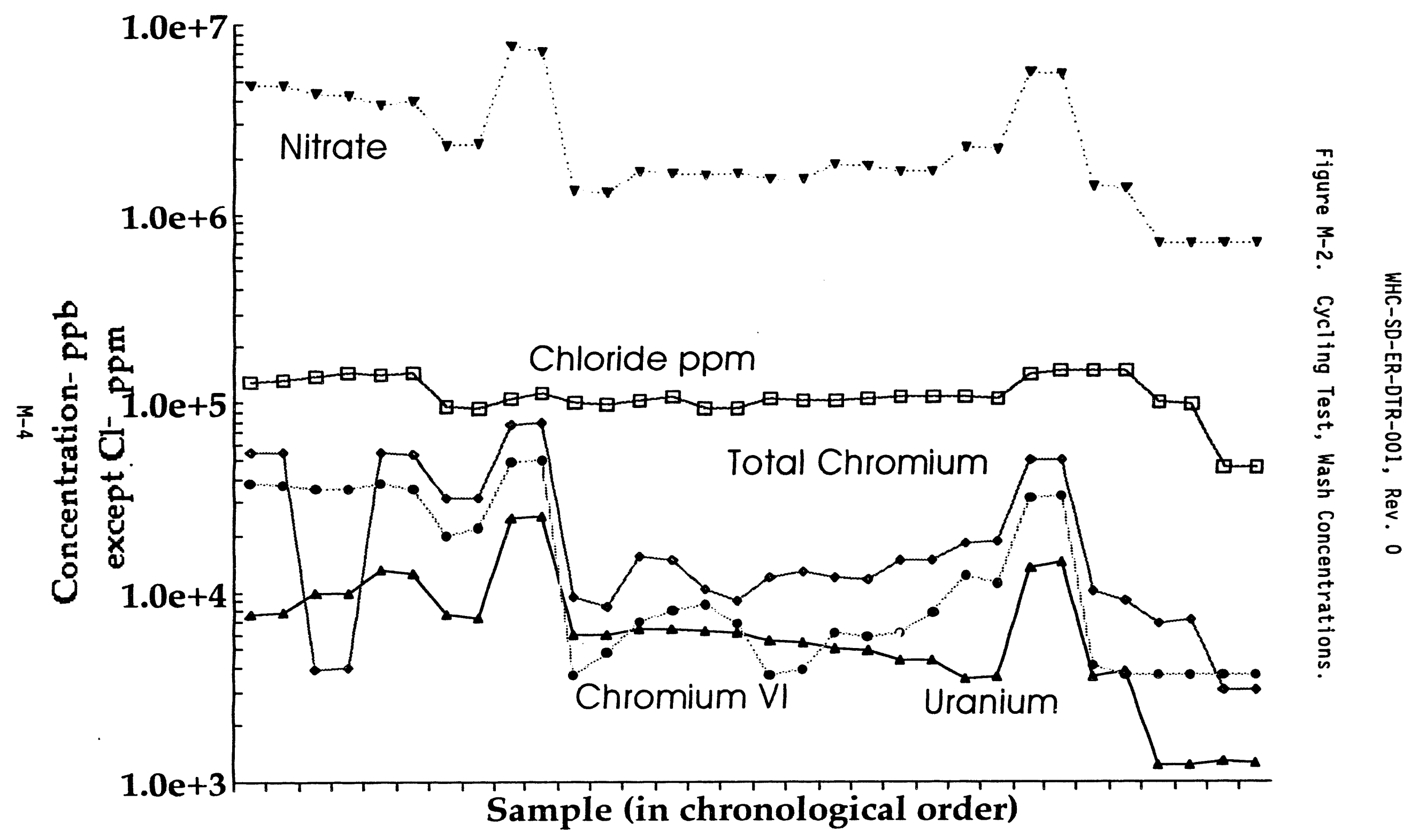




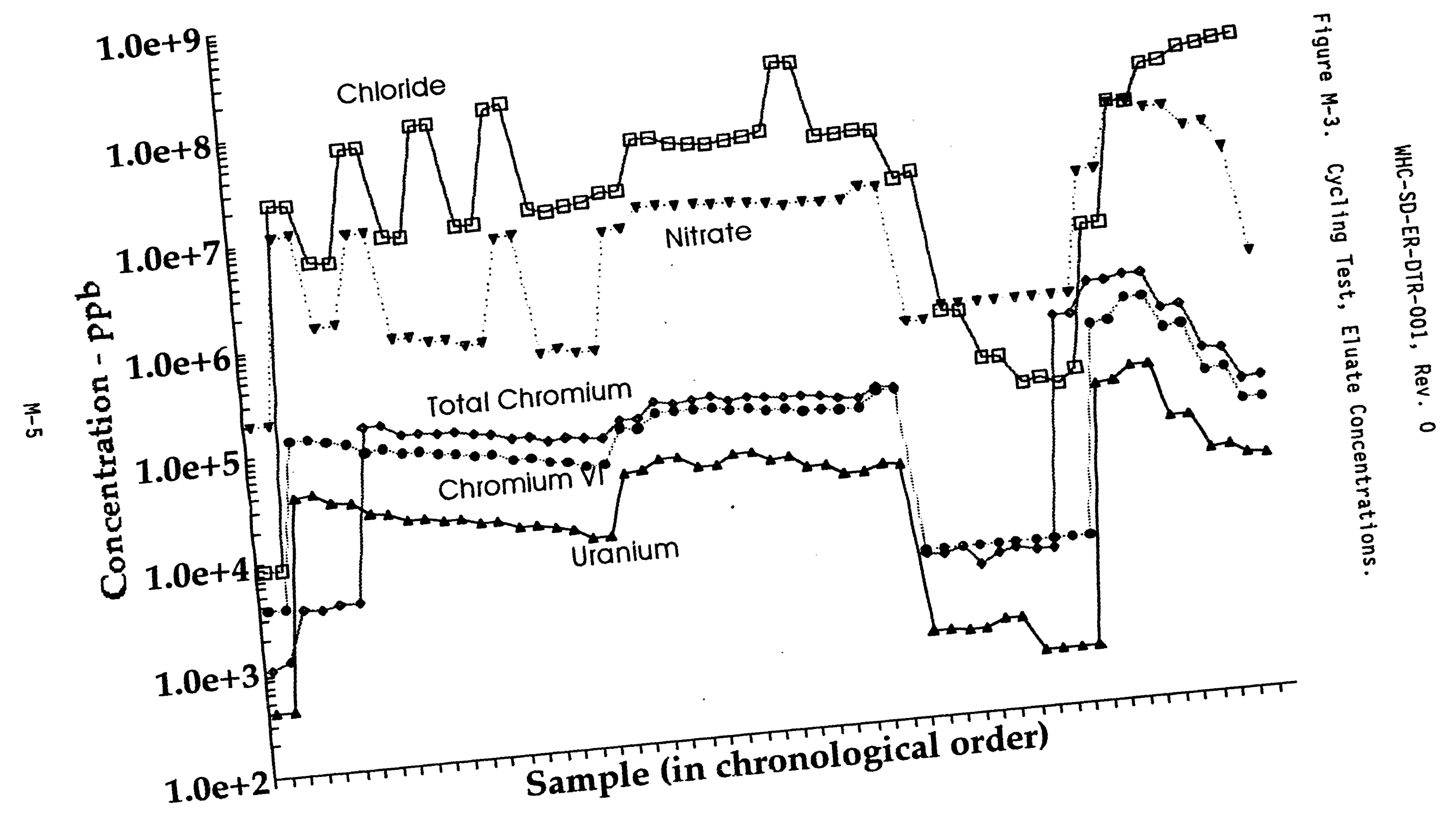


Figure M-4. Cycle 10, Concentration Versus Column Volumes.

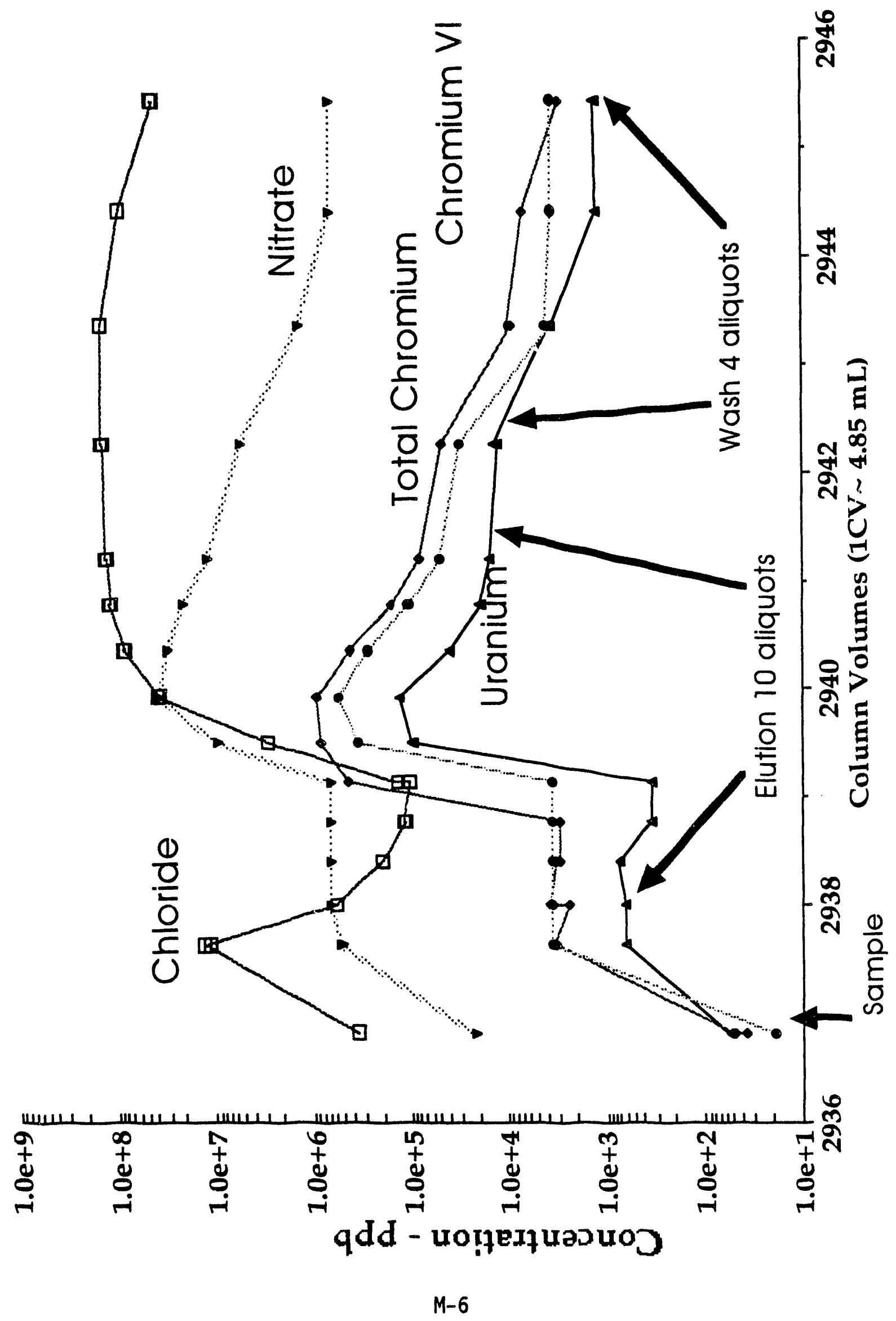




\begin{tabular}{|c|c|c|c|c|c|c|c|}
\hline $\begin{array}{l}\text { Laboratory } \\
\text { sample : }\end{array}$ & $\begin{array}{l}\text { Project } \\
\text { sample : }\end{array}$ & $\begin{array}{l}\text { Cumulative Column } \\
\text { Volumes (1 Column } \\
\text { volume }-4.85 \mathrm{~mL} \text { ) }\end{array}$ & $\begin{array}{c}\text { Uranium } \\
\text { Concentration } \\
\text { (ppb) }\end{array}$ & $\begin{array}{c}\text { Total Chromium } \\
\text { Concentration } \\
\text { (ppb) }\end{array}$ & $\begin{array}{l}\text { Chromium (VI) } \\
\text { Concentration } \\
\text { (ppb) }\end{array}$ & $\begin{array}{c}\text { Nitrate } \\
\text { Concentration } \\
\text { (ppb) }\end{array}$ & $\begin{array}{c}\text { Chloride } \\
\text { Concentration }\end{array}$ \\
\hline P 1779. & CK2OBAO1 & & 2.7 & 45 & 19.4 & 3443 & 6.5 \\
\hline P 1779 & CK2OBAO1 & & 2.7 & 42 & 19.4 & 3443 & 6.9 \\
\hline P 1782. & CK31EA01 & 311.5 & 408 & 1020 & 3640 & 198508 & 8.6 \\
\hline P 1782. & CK31EA01 & 311.5 & 400 & 1170 & 3640 & 199514 & 8.6 \\
\hline P 1783. & CK31EAO2 & 311.9 & $\mathbf{3 8 7 0 0}$ & 3480 & 136000 & 11414000 & 22744 \\
\hline P:783. & CK31EAO2 & 311.9 & 40800 & 3450 & 138000 & 11481400 & 21984 \\
\hline P 1784. & CK31EA03 & 312.4 & 33000 & 3760 & 125000 & 1483670 & 6150 \\
\hline P 1784. & CK31EAO3 & 312.4 & 31900 & 3650 & 117000 & 1542680 & 6071 \\
\hline P 1785. & CK31EAO4 & 312.8 & 24030 & 163000 & 94500 & 10562900 & 68790 \\
\hline P 1785. & CK31EAO4 & 312.8 & 23900 & 161000 & 99600 & 10658600 & 68321 \\
\hline P 1791. & CK31EA05 & 313.2 & 19500 & 123000 & 85200 & 1007840 & 9300 \\
\hline P 1791. & CK31EA05 & 313.2 & 19400 & 125000 & 84500 & 1012070 & 9051 \\
\hline P 1786. & CK31EA06 & 313.5 & 18400 & 122000 & 80600 & 901663 & 100934 \\
\hline P 1786. & CX31EA06 & 313.5 & 18300 & 118000 & 77200 & 921196 & 99996 \\
\hline P 1787. & CK31EA07 & 313.9 & 15800 & 109000 & 69300 & 779567 & 10305 \\
\hline P 1787. & CK31EA07 & 313.9 & 15900 & 108000 & 70300 & 785582 & 10259 \\
\hline P 1788. & CK31EA08 & 314.3 & 13500 & 94900 & 59300 & 7445010 & 124606 \\
\hline P 1788. & СКЗ1ЕАО8 & 314.3 & 13500 & 93300 & 59100 & 7825000 & 130877 \\
\hline P 1789. & CK31EA09 & 314.7 & 12700 & 84200 & 51800 & 549290 & 12869 \\
\hline P 1789. & CKЗ1EA09 & 314.7 & 11700 & 84700 & 50300 & 606060 & 11686 \\
\hline P 1790. & CK31EA10 & 315.2 & 9170 & 82600 & 44900 & 522227 & 12540 \\
\hline P 1790. & CK31EA10 & 315.2 & 9240 & 78500 & 44400 & 532463 & 12992 \\
\hline P 1797. & CK31EBO1 & 653.1 & 34600 & 111000 & 92500 & 6719430 & 15635 \\
\hline P 1797. & CK31EBO1 & 653.1 & 35000 & 109000 & 91300 & 6997520 & 15930 \\
\hline P 1800. & CK31ECO1 & 957.5 & 43430 & 153000 & 119000 & 10850600 & 47116 \\
\hline P 1800. & CK31ECO1 & 957.5 & 43790 & 142000 & 119000 & 10631700 & 46840 \\
\hline
\end{tabular}




\begin{tabular}{|c|c|c|c|c|c|c|c|}
\hline $\begin{array}{l}\text { Laboratory } \\
\text { sample : }\end{array}$ & $\begin{array}{l}\text { Project } \\
\text { sample * }\end{array}$ & $\begin{array}{l}\text { Cumulative Column } \\
\text { Volumes (1 Column } \\
\text { volume }-4.85 \mathrm{~mL} \text { ) }\end{array}$ & $\begin{array}{c}\text { Uranium } \\
\text { Concentration } \\
\text { (ppb) }\end{array}$ & $\begin{array}{c}\text { Total Chromium } \\
\text { Concentration } \\
\text { (ppb) }\end{array}$ & $\begin{array}{l}\text { Chromium (VI) } \\
\text { Concentration } \\
\text { (ppb) }\end{array}$ & $\begin{array}{c}\text { Nitrato } \\
\text { Concentration } \\
\text { (ppb) }\end{array}$ & $\begin{array}{c}\text { Chloride } \\
\text { Concentration }\end{array}$ \\
\hline P 1803. & CK31ED01 & 1260.9 & 34440 & 150000 & 118000 & 10412700 & 39132 \\
\hline P 1803. & CK31ED01 & 1260.9 & 34280 & 155000 & 121000 & 10134900 & 38562 \\
\hline P 1806. & CK31EEO1 & 1548.9 & 41700 & 137000 & 112000 & 9827310 & 36446 \\
\hline P 1806. & CK31EEO1 & 1548.9 & 41510 & 143000 & 109000 & 9840590 & 37182 \\
\hline P 1809. & CK31EF01 & 1819.8 & 34060 & 133000 & 103000 & 9425250 & 39822 \\
\hline P 1809. & CK31EFO1 & 1819.8 & 35940 & 137000 & 101000 & 9199310 & 42474 \\
\hline P 1812. & CK31EG01 & 2062.2 & 28040 & 130000 & 93500 & 8476550 & 188334 \\
\hline P 1812. & CK31EGO1 & 2062.2 & 27730 & 128000 & 91800 & 8718060 & 130642 \\
\hline P 1815. & CK31EHO1 & 2290.7 & 22010 & 114000 & $8960 n$ & 8243960 & 35212 \\
\hline P 1815. & CK31EHO1 & 2290.7 & 22210 & 110000 & 88400 & 8188840 & 34231 \\
\hline P 1818. & CK31EIO1 & 2608.3 & 25190 & 134000 & 128000 & 10735100 & 36221 \\
\hline P 1818. & CK31EIO1 & 2608.3 & 24760 & 129000 & 127000 & 10106400 & 34106 \\
\hline P 1821. & CK31EJO1 & 2937.6 & 627.2 & 3430 & 3640 & 532000 & 11607 \\
\hline P 1821. & CK31EJO1 & 2937.6 & 625.8 & 3230 & 3640 & 528000 & 13186 \\
\hline P 1822. & CK31EJO2 & 2938 & 607.7 & 3740 & 3640 & 692040 & 610 \\
\hline P 1822. & CK31EJO2 & 2938 & 607.6 & 2420 & 3640 & 692040 & 603 \\
\hline P 1823. & CKЗ1EJO3 & 2938.4 & 734 & 3030 & 3640 & 692040 & 206 \\
\hline P 1823. & CK31EJO3 & 2938.4 & 729 & 3230 & 3640 & 692040 & 206 \\
\hline P 1824. & CX31EJ04 & 2938.8 & 336 & 3010 & 3640 & 692040 & 112 \\
\hline P 1824 & CK31EJO4 & 2938.8 & 343 & 3010 & 3640 & 692040 & 120 \\
\hline P 1825. & CK31EJ05 & 2939.1 & 337 & 447000 & 3640 & 692040 & 101 \\
\hline P 1825. & CK31EJ05 & 2939.1 & 333 & 443000 & 3640 & 692040 & 139 \\
\hline P 1826 & CK31EJ06 & 2939.5 & 92100 & 876000 & 351000 & 9513730 & 3069 \\
\hline P 1826. & CK31EJ06 & 2939.5 & 95899.9 & 881000 & 353000 & 9759220 & 3090 \\
\hline P 1827. & CK31EJ07 & 2939.9 & 130000 & 930000 & 571000 & 39188200 & 40667 \\
\hline P 1827. & CK31EJ07 & 2939.9 & 130000 & 941000 & 573000 & 39238000 & 39367 \\
\hline
\end{tabular}




\begin{tabular}{|c|c|c|c|c|c|c|c|}
\hline $\begin{array}{l}\text { Laboratory } \\
\text { sample * }\end{array}$ & $\begin{array}{l}\text { Project } \\
\text { sample : }\end{array}$ & $\begin{array}{l}\text { Cumulative Column } \\
\text { Volumes (1 Column } \\
\text { volume- } 4.85 \mathrm{~mL} \text { ) }\end{array}$ & $\begin{array}{c}\text { Uranium } \\
\text { Concontration } \\
\text { (ppb) }\end{array}$ & $\begin{array}{c}\text { Total Chromium } \\
\text { Concentration } \\
\text { (ppb) }\end{array}$ & $\begin{array}{c}\text { Chromium (VI) } \\
\text { Conceritration } \\
\text { (ppb) }\end{array}$ & $\begin{array}{c}\text { Nitrate } \\
\text { Concentration } \\
\text { (ppb) }\end{array}$ & $\begin{array}{c}\text { Chloride } \\
\text { Concentration }\end{array}$ \\
\hline P 1828. & CK31EJ08 & 2940.3 & 39600 & 432000 & 282000 & 32792000 & 86325 \\
\hline P 1828. & CK31EJ08 & 2940.3 & 40700 & 437000 & 285000 & 32967000 & 90691 \\
\hline P 1829. & CK31EJ09 & 2940.8 & 19200 & 165000 & 103000 & 21475000 & 118008 \\
\hline P 1829. & CK31EJ09 & 2940.8 & 20000 & 164000 & $10<000$ & 21634000 & 121821 \\
\hline P 1830. & CK31EJ1O & 2941.2 & 16000 & 80400 & 51500 & 12008000 & 132375 \\
\hline P 1830. & CK31EJ1O & 2941.2 & 15700 & 81300 & 52000 & 111913000 & 136732 \\
\hline P 1781. & CK31SA01 & 310.7 & 5 & 29.8 & 19.4 & 11050 & 1591 \\
\hline P 1781. & CK31SA01 & 310.7 & 5 & 29.8 & 19.4 & 10960 & 1629 \\
\hline P 1796. & CK31SBO1 & 648.4 & 5.4 & 298 & 19.4 & 25960 & 1259 \\
\hline P 1796. & CK31SBO1 & 648.4 & 5.7 & 298 & 19.4 & 25780 & .1277 \\
\hline P 1799. & CK31SCO1 & 952.7 & 36 & 43 & 19.4 & 11450 & 585 \\
\hline P 1799. & CK3isco1 & 952.7 & 36 & 33 & 19.4 & 11270 & 591. \\
\hline P 1802. & CK31SD01 & 1256.3 & 43 & 42 & 19.4 & 12990 & 440 \\
\hline P 1802. & CK31SD01 & 1256.3 & 43 & 34 & 19.4 & 13170 & 434 \\
\hline P 1805. & CK31SEO1 & 1544.3 & 69 & 69 & 19.4 & 9610 & 486 \\
\hline P 1805. & CK31SEO1 & 1544.3 & 67 & 67 & 19.4 & 9690 & 485 \\
\hline P 1808. & CK31SFO1 & 1815 & 98 & 43 & 27.2 & 8460 & 582 \\
\hline P 1808. & CK31SFO1 & 1815 & 99 & 45 & $19: 4$ & 8470 & 571 \\
\hline P 1811. & CK31SG01 & 2057.9 & 106 & 42 & 27.2 & 7082 & 693 \\
\hline P 1811. & CK31SG01 & 2057.9 & 105 & 37 & 19.4 & 7094 & 706 \\
\hline P 1814. & CK31SHO1 & 2286.4 & 155 & 40 & 32.4 & 6523 & 620 \\
\hline P 1814. & CK31SHO1 & 2286.4 & 150 & 49 & 32.4 & 6530 & 617 \\
\hline P 1817. & CK31S101 & 2603.8 & 79 & 61 & 19.4 & 16870 & 413 \\
\hline P 1817. & CK31SI01 & 2603.8 & 80 & 550 & 19.4 & 17010 & 417 \\
\hline P 1820. & CK31SJJ01 & 2936.8 & 56 & 49 & 19.4 & 22070 & 360 \\
\hline P 1820. & CK31SJ01 & 2936.8 & 55 & 37 & 19.4 & 22230 & 364 \\
\hline
\end{tabular}




\begin{tabular}{|c|c|c|c|c|c|c|c|}
\hline $\begin{array}{l}\text { Laboratory } \\
\text { samplo }\end{array}$ & $\begin{array}{l}\text { Projoct } \\
\text { samplo }\end{array}$ & $\begin{array}{l}\text { Cumulative Column } \\
\text { Volumes (1 Column } \\
\text { volume- } 4.85 \mathrm{~mL} \text { ) }\end{array}$ & $\begin{array}{c}\text { Uranium } \\
\text { Concentration } \\
\text { (ppb) }\end{array}$ & $\begin{array}{c}\text { Total Chromium } \\
\text { Concentration } \\
\text { (ppb) }\end{array}$ & $\begin{array}{l}\text { Chromium (VI) } \\
\text { Concentration } \\
\text { (ppb) }\end{array}$ & $\begin{array}{c}\text { Nitrate } \\
\text { Concentration } \\
\text { (ppb) }\end{array}$ & $\begin{array}{c}\text { Chloride } \\
\text { Concentration }\end{array}$ \\
\hline P 1780. & СКЗ1ТАО1 & & 853 & 2100 & 1640 & 203594 & 3 \\
\hline P 1780. & CK31TA01 & & 846 & 2150 & 1750 & 203468 & 3.1 \\
\hline P 1835. & CK31TJ01 & & 497 & 2340 & 1860 & 202947 & 3.1 \\
\hline P 1835. & CK31TJ01 & & 508 & 2310 & 1870 & 202328 & 2.8 \\
\hline P 1792. & CK31WA01 & 316.2 & 7730 & 54900 & 38100 & 4753710 & 127700 \\
\hline P 1792. & CK31WA01 & 316.2 & 7860 & 54500 & 37100 & 4801120 & 131520 \\
\hline P 1793. & CK31WAO2 & 317.2 & 9960 & 3940 & 35400 & 4302520 & 138823 \\
\hline P 1793. & CK3IWAO2 & 317.2 & 9810 & 4040 & 34900 & 4264290 & 144298 \\
\hline P 1794. & CK31WAO3 & 318.2 & 12900 & 54600 & 38100 & 3824780 & 142710 \\
\hline P 1794. & CK31WAO3 & 318.2 & 12500 & 53500 & 35600 & 3946900 & 145130 \\
\hline P 1795. & CK3IWAO4 & 320.9 & 7720 & 31600 & 20000 & 2344670 & 96294 \\
\hline P 1795. & CK31WA04 & 320.9 & 7290 & 31200 & 21700 & 2405750 & 94262 \\
\hline P 1798. & CK31WBO1 & 658.3 & 24400 & 78300 & 49100 & 7686570 & 105182 \\
\hline P 1798. & CK31WBO1 & 658.3 & 24800 & 79400 & 50300 & 7172500 & 111790 \\
\hline P 1801. & CK31WCO1 & 962.5 & 5900 & 9390 & 3640 & 1320100 & 99070 \\
\hline P 1801. & CK31WCO1 & 962.5 & 6000 & 8380 & 4860 & 1318760 & 97157 \\
\hline P 1804. & CK3IWDOI & 1265.6 & 6400 & 15400 & 7060 & 1679920 & 101794 \\
\hline P 1804. & CK31WD01 & 1265.6 & 6400 & 14700 & 8030 & 1650650 & 106367 \\
\hline P 1807. & CK31WEO1 & 1553.4 & 6200 & 10300 & 8520 & 1606520 & 94143 \\
\hline P 1807. & CK31WEO1 & 1553.4 & 6100 & 8990 & 6810 & 1627910 & 93045 \\
\hline P 1810. & CK31WF01 & 1824.1 & 5600 & 12020 & 3640 & 1548790 & 104167 \\
\hline P 1810. & CK31WF01 & 1824.1 & 5400 & 12830 & 3880 & 1520210 & 103370 \\
\hline P 1813. & CK31WG01 & 2066.7 & 5000 & 11900 & 6080 & 1843750 & 101952 \\
\hline P 1813. & CK31WG01 & 2066.7 & 4900 & 11600 & 5840 & 1823140 & 103800 \\
\hline P 1816. & CK31WHO1 & 2295.2 & 4367 & 14800 & 6080 & 1679120 & 106368 \\
\hline P 1816. & CK31WHO1 & 2295.2 & 4423 & 14500 & 7790 & 1690510 & 106071 \\
\hline
\end{tabular}




\begin{tabular}{|c|c|r|r|r|r|r|r|}
\hline $\begin{array}{c}\text { Laboratory } \\
\text { sample : }\end{array}$ & $\begin{array}{c}\text { Projoct } \\
\text { sample }\end{array}$ & $\begin{array}{c}\text { Cumulativo Column } \\
\text { Volumes } \\
\text { volume- } 4.85 \mathrm{~mL}\end{array}$ & $\begin{array}{c}\text { Uranium } \\
\text { Concentration } \\
\text { (ppb) }\end{array}$ & $\begin{array}{c}\text { Total Chromium } \\
\text { Concentration } \\
\text { (ppb) }\end{array}$ & $\begin{array}{c}\text { Chromium (VI) } \\
\text { Concentration } \\
\text { (ppb) }\end{array}$ & $\begin{array}{c}\text { Nitrato } \\
\text { Concentration } \\
\text { (ppb) }\end{array}$ & $\begin{array}{c}\text { Chloride } \\
\text { Concentration }\end{array}$ \\
\hline P 1819. & CK31W101 & 2612.7 & 3500 & 18100 & 12200 & 2294030 & 107953 \\
\hline P 1819. & CK31W101 & 2612.7 & 3600 & 18600 & 11200 & 2247260 & 105157 \\
\hline P 1831. & CK31WJ01 & 2942.3 & 13500 & 49700 & 31500 & 5557540 & 142980 \\
\hline P 1831. & CK31WJ01 & 2942.3 & 14300 & 49700 & 32000 & 5482780 & 149327 \\
\hline P 1832. & CK31WJ02 & 2943.4 & 3570 & 10100 & 4130 & 1389790 & 149374 \\
\hline P 1832. & CK31WJ02 & 2943.4 & 3850 & 9090 & 3640 & 1377680 & 148947 \\
\hline P 1833. & CK31WJ03 & 2944.4 & 1220 & 6870 & 3640 & 692040 & 99109 \\
\hline P 1833. & CK31WJ03 & 2944.4 & 1230 & 7070 & 3640 & 692040 & 97074 \\
\hline P 1834. & CK31WJ04 & 2945.4 & 1300 & 3010 & 3640 & 692040 & 45106 \\
\hline P 1834. & CK31WJ04 & 2945.4 & 1270 & 3010 & 3640 & 692040 & 45940 \\
\hline
\end{tabular}


WHC-SD-ER-DTR-001, Rev. 0 

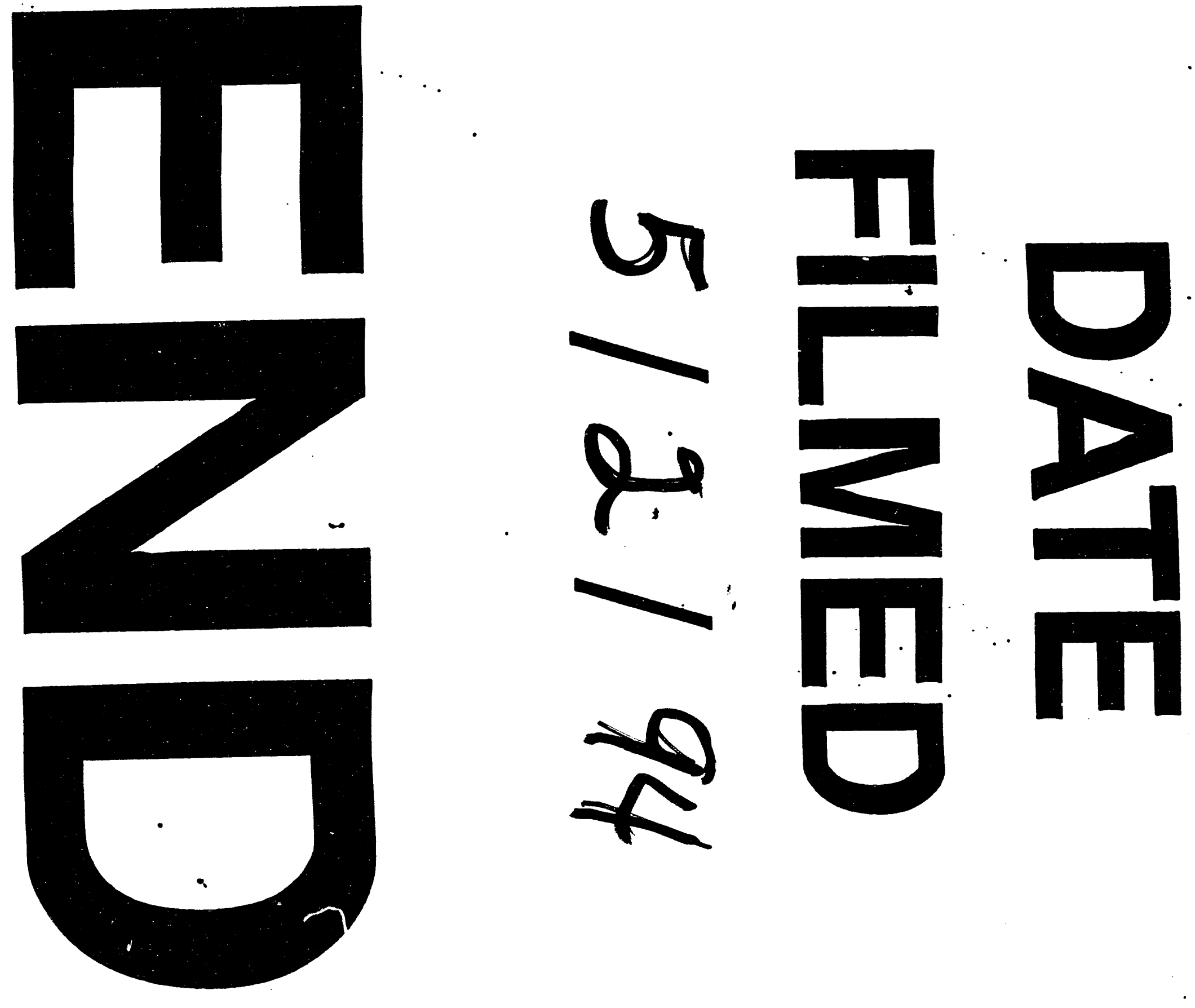

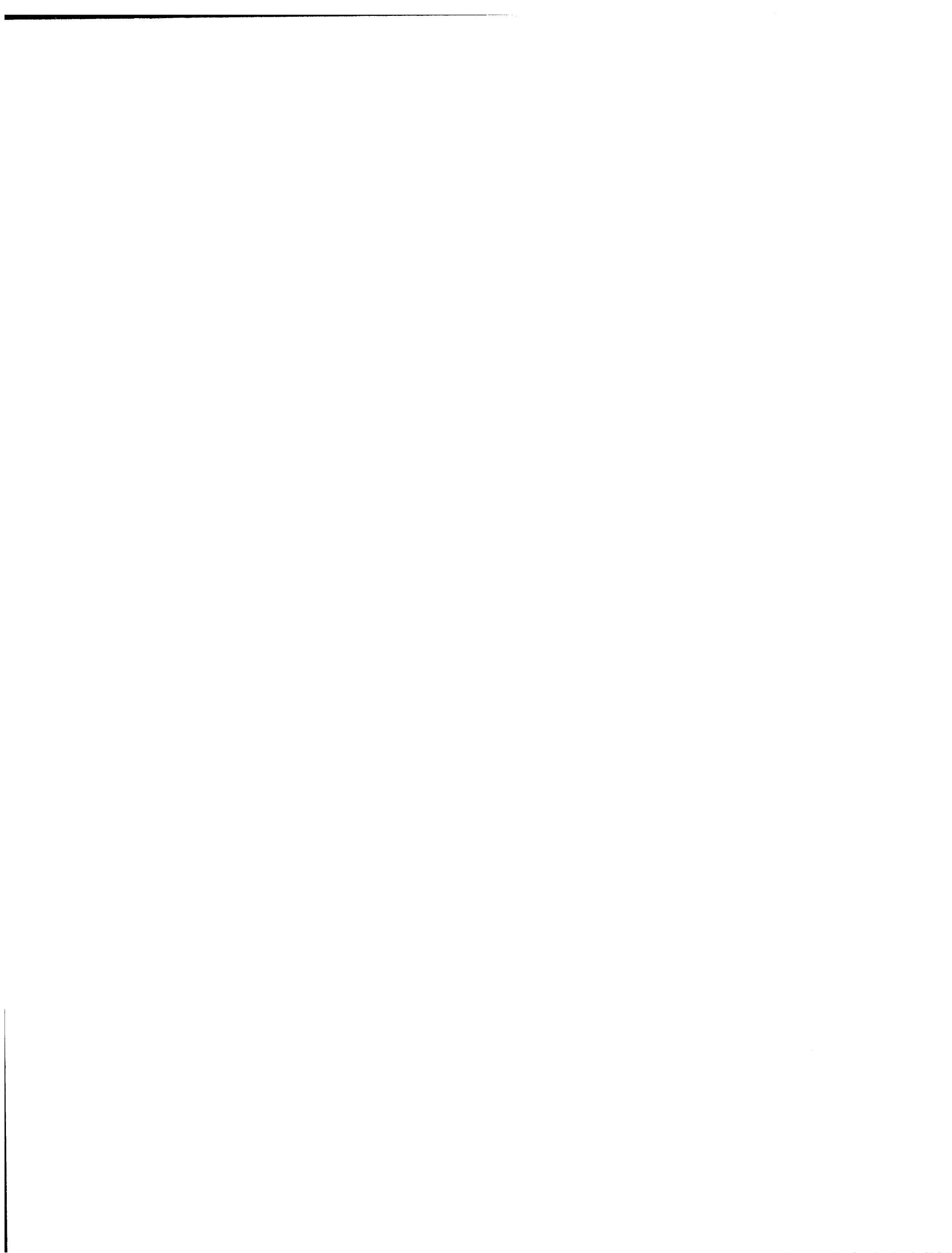